DEPARTMENT OF THE INTERIOR

U.S. GEOLOGICAL SURVEY

\title{
GEOLOGY OF EAST-CENTRAL ALASKA
}

by

James H. Dover ${ }^{1}$

Open-File Report 90-289

This report is preliminary and has not been reviewed for conformity with U.S. Geological Survey editorial standards (or with the North American Stratigraphic Code). Any use of trade, product, or firm names is for descriptive purposes only and does not imply endorsement by the U.S. Government.

$1_{\text {Anchorage, Alaska }}$ 
This report makes available the chapter on the "Geology of east-central Alaska" of the Alaska DNAG volume, which is still in preparation. A few references, given herein as "this volume" citations, refer to other chapters that will appear in the same DNAG volume. These references are necessarily incomplete as to publication date, volume number, and page numbers. Nevertheless, these references are included here to alert the reader to the inclusion and eventual accessibility of the relevant data in the Alaskan DNAG volume. 
CONTENTS

$\underline{\text { Page }}$

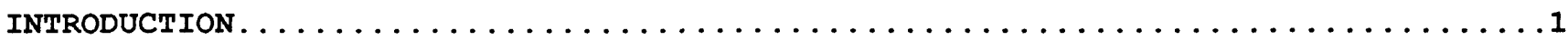

GEOLOGIC SUMMARIES OE REPRESENTATIVE AREAS.......................

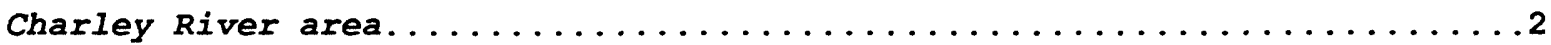

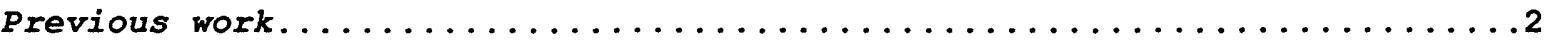

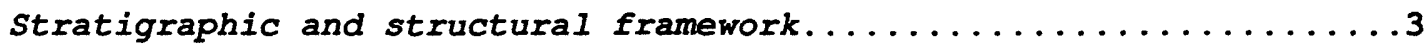
Stratigraphic variations in the Charley River

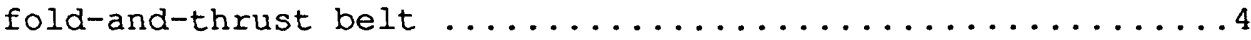

Direction and amount of tectonic transport.............

Timing of fold-and-thrust belt deformation............

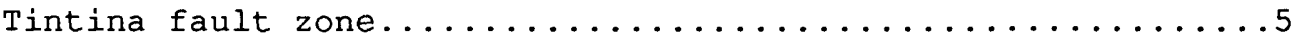

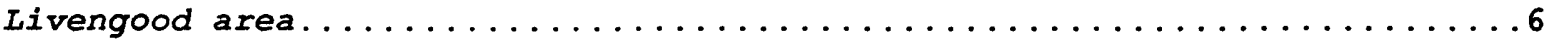

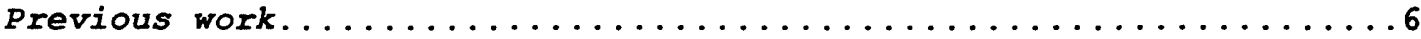

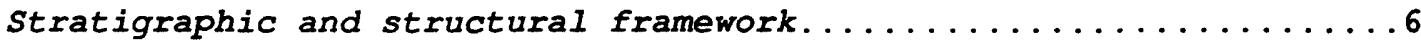

Stratigraphic belts and terranes..................

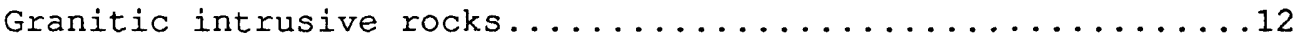

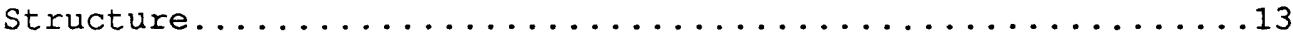

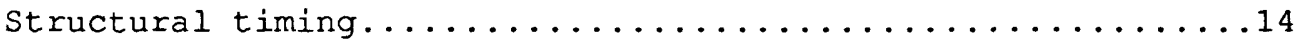

The Livengood area as a segment of the Charley

River fold-and-thrust belt displaced by the

Victoria Creek-Kaltag and Tozitna splays of

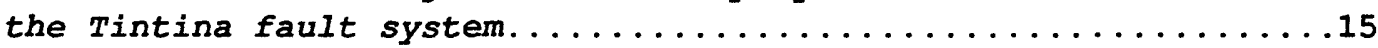

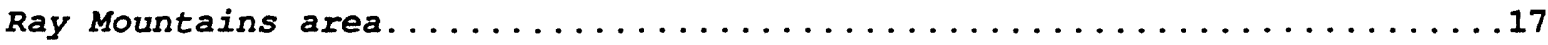

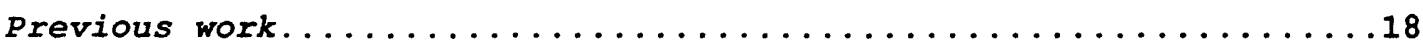

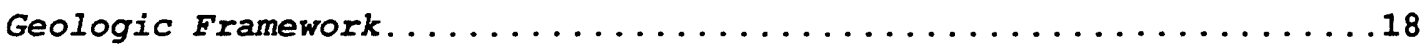

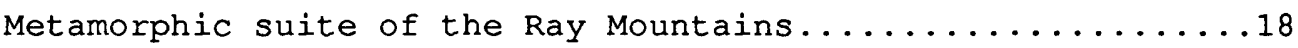

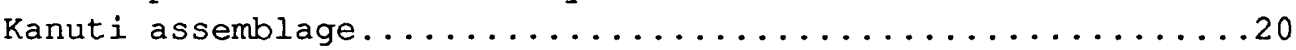

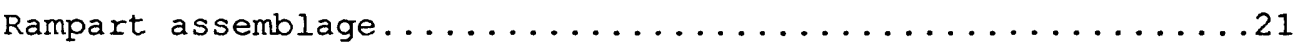

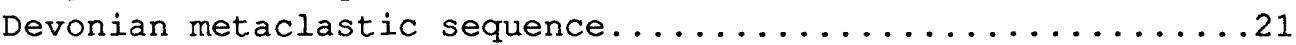

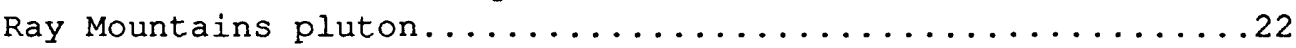

Brittle fracture and strike-slip faulting--

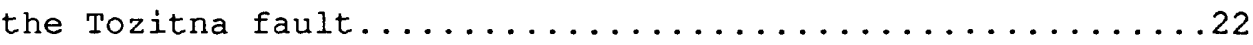

Implications of new mapping between Tozitna

and Yukon Rivers...........................23

protoliths of metamorphic rocks in the Ray

Mountains area.............................24

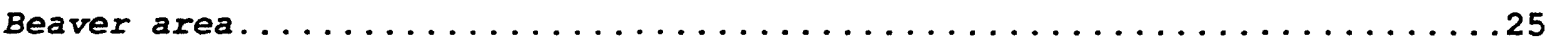

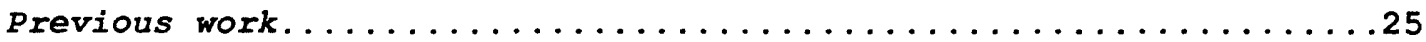

Stratigraphic and structural framework.......................

Mafic igneous complexes of the Beaver and

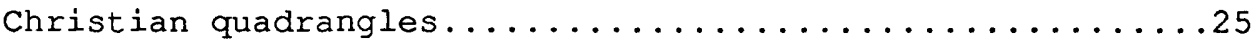

Low-grade metamorphic rocks of the Ruby geanticline......26

Weakly metamorphosed Devonian clastic rocks............26 


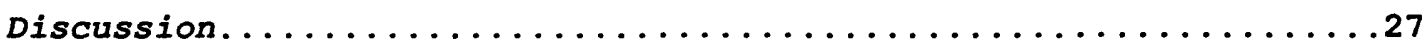

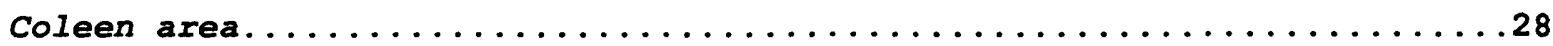

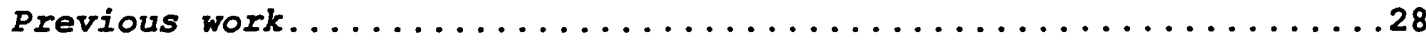

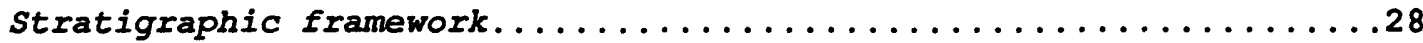

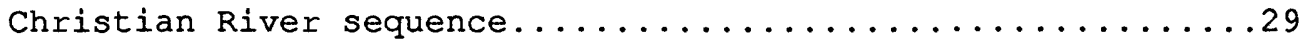

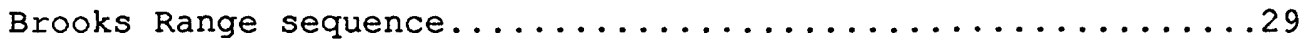

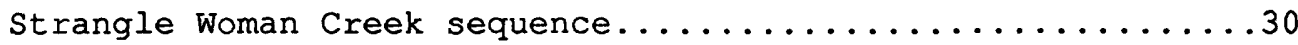

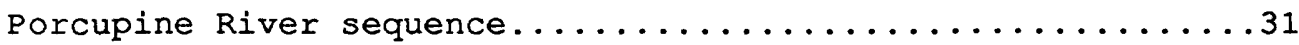

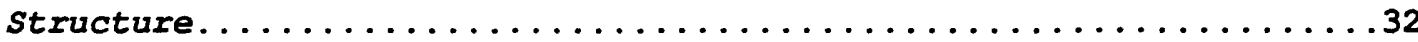

THE GEOLOGY OF EAST-CENTRAL ALASKA IN AN INTERREGIONAL CONTEXT $\ldots \ldots \ldots \ldots \ldots \ldots 32$

Terrane subdivisions and paleogeographic setting--

a regional stratigraphic perspective...................... 32

Correlation and North American affinity of rocks and terranes in the Charley River and Livengood

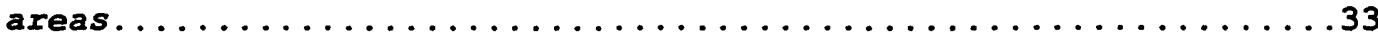

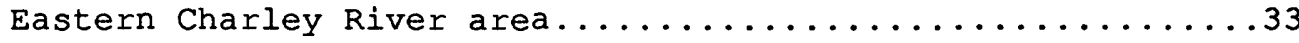

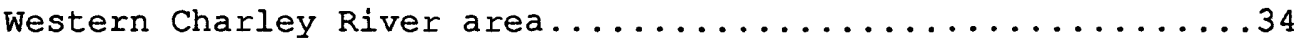

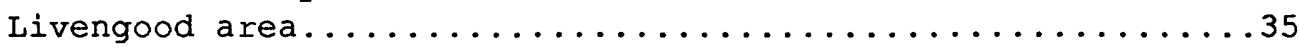

Regional geologic ties between the Ray Mountains

and Beaver areas, the southeastern Brooks Range,

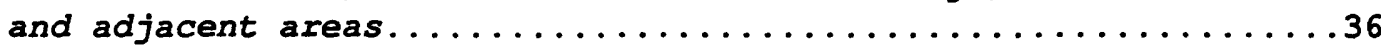

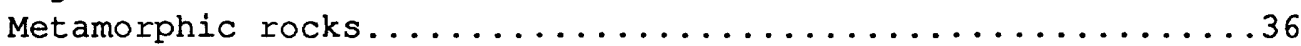

Devonian metaclastic sequence........................ 37

Other correlations involving rocks of the

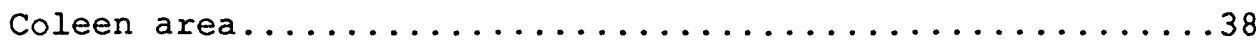

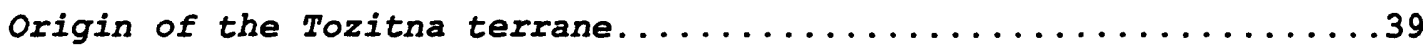

Mesozoic flysch sequence.......................

Crystalline terranes of interior Alaska--continental

arc origin.................................42

Distribution and significance of fold-and-thrust-belts..........43

Major strike-slip fault systems--pattern, timing,

significance, and restoration of offset.................44

Oroclinal bending and crustal rotation...................

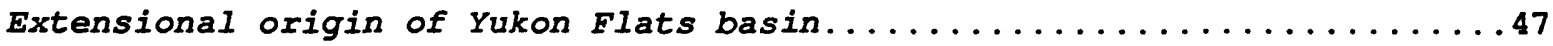

PALEOGEOGRAPHIC AND GEOTECTONIC MODEL $\ldots \ldots \ldots \ldots \ldots \ldots \ldots \ldots \ldots \ldots \ldots \ldots \ldots \ldots \ldots$

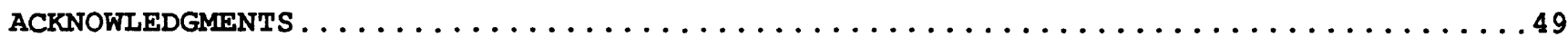

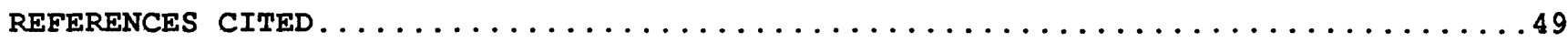


LIST OF ILLUSTRATIONS

Figure

page

1 Index map showing area of study, quadrangle locations,

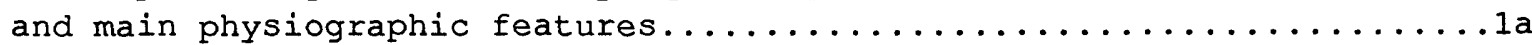

2 Major geotectonic features and tectonostratigraphic

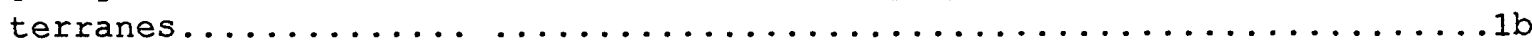

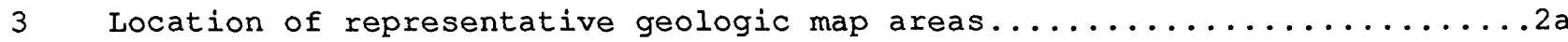

4 Geologic map of the Charley River area, and part of adjacent Yukon Territory...........................

5 Generalized stratigraphic columns of the Charley River area..........3b

6 Structure sections of the eastern Charley River fold-and-

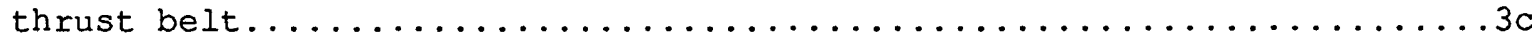

7 Schematic pre-Jurassic statigraphic relations interpreted from restored thrust plates, eastern Charley River

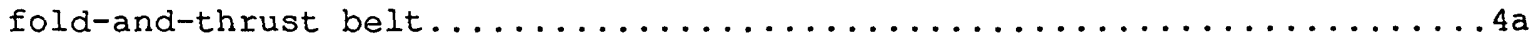

8 Geologic map of the Livengood area........................

9 Generalized stratigraphic columns of the Livengood area...........7b

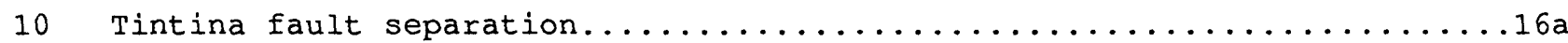

11 Geologic map of the Ray Mountains area......................

12 Generalized stratigraphic columns of the Ray Mountains area..........18c

13 Sketches of superimposed mesoscopic structures.................19a

14 Possible protolith model for the metamorphic suite

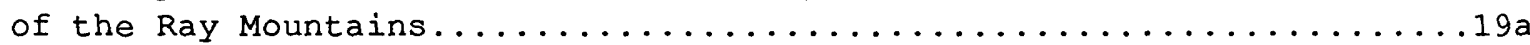

15 Geologic map of the Beaver area........................25a

16 Generalized stratigraphic columns of the Beaver area............25b

17 Geologic map of the Coleen area.......................... $28 a, b$

18 Generalized stratigraphic columns of the coleen area............28c

19 Comparison and correlation of stratigraphic sections of the Ruby geanticline and Yukon-Tanana upland with

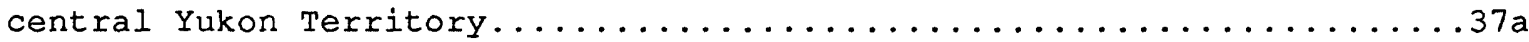


20 Regional tectonic map of east-central Alaska region and part of adjacent Yukon Territory $\ldots \ldots \ldots \ldots \ldots \ldots \ldots \ldots \ldots \ldots \ldots \ldots \ldots$

21 Pre-Tintina geologic configuration.....................46a

22 Comparison of fault patterns in map and cross-section views........46b

23 Possible origins of extensional basins..................47a

24 Regional geotectonic model $\ldots \ldots \ldots \ldots \ldots \ldots \ldots \ldots \ldots \ldots \ldots \ldots \ldots \ldots$

* Oversized figure--reproduced on 11" X 17" or larger sheets found at the end of the report; user may wish to trim, if necessary, and(or) fold to page size and integrate with text 
INTRODUCTION

The east-central Alaska region extends west from the Canadian border to the southeast edge of the Koyukuk basin, and north from the Yukon-Tanana upland to the southeast flank of the Brooks Range (fig. 1). The region encompasses all or parts of thirteen 1:250,000 quadrangles and covers an area of about $140,000 \mathrm{~km}^{2}$.

The physiography of the region (Wahrhaftig, this volume) is extremely diverse (fig. 1). Steep mountainous areas having high to moderate relief include parts of the Ogilvie Mountains, White Mountains, Yukon-Tanana upland, Ray Mountains, and southeastern Brooks Range. Areas of dissected plateaus and rolling hills with moderate to low relief include the Porcupine plateau and the Kokrines-Hodzana upland. Lowlands characterize the Yukon Flats basin and extend upstream into other parts of the Yukon River and Porcupine River drainage basins.

Bedrock exposures are severely limited in most of the east-central Alaska region. Mountainous areas are locally glaciated, but except in the most rugged parts of the Ogilvie Mountains and parts of the Brooks Range, bedrock is extensively mantled by surficial cover and the colluvial products of alpine weathering processes. Stream cuts commonly offer the best exposures in generally forested or tundra covered areas of moderate relief. Lowland areas have few preCenozoic bedrock exposures because of extensive surficial cover and tundra.

The pioneering reconnaissance studies by $J$. B. Mertie and his predecessors were carried out in the east-central Alaska region prior to 1940 . A relatively small group of geologists conducted the basic geologic mapping during the 1960's and 1970's that defined the stratigraphic and structural framework of the region and that forms the foundation of more recent studies. Among these mappers, to whom I am especially indebted, are E. E. Brabb and Michael Churkin, Jr., in the Charley River and Black River quadrangles; H. L. Foster, in the Eagle quadrangle and the Yukon-Tanana upland; R. M. Chapman and F. R. Weber, in the Tanana and Livengood quadrangles; and W. P. Brosgè and H. N. Reiser, in the southeastern Brooks Range. Although the list of references accompanying this chapter attests to the number of contributors to the geology of the region, the fundamental contributions of these seven cannot be overestimated. Among the major geologic features of the east-central Alaska region that they helped define are the Charley River, Livengood, and southeastern Brooks Range fold-and-thrust belts; the lowgrade metamorphic and plutonic complexes of the Ruby geanticline, Yukon-Tanana upland, and southern Brooks Range; the Tozitna mafic-igneous and sedimentary assemblage; and regionally prominent strike-slip fault systems (fig. 2). More recent work has emphasized the wide range of stratigraphic facies and structural styles characterizing the east-central Alaska region. This work has led Churkin and others (1982) and Silberling and Jones (1984) to subdivide the region into numerous tectonostratigraphic (lithotectonic) terranes and subterranes (fig. 2; Silberling and others, this volume), the identity, origins, and significance of which are presently under debate. The application of terrane terminology and concepts to the east-central Alaska region, and their implications with regard to accretionary tectonics and paleogeographic reconstruction in interior Alaska, raises a number of fundamental questions. Among them are: 


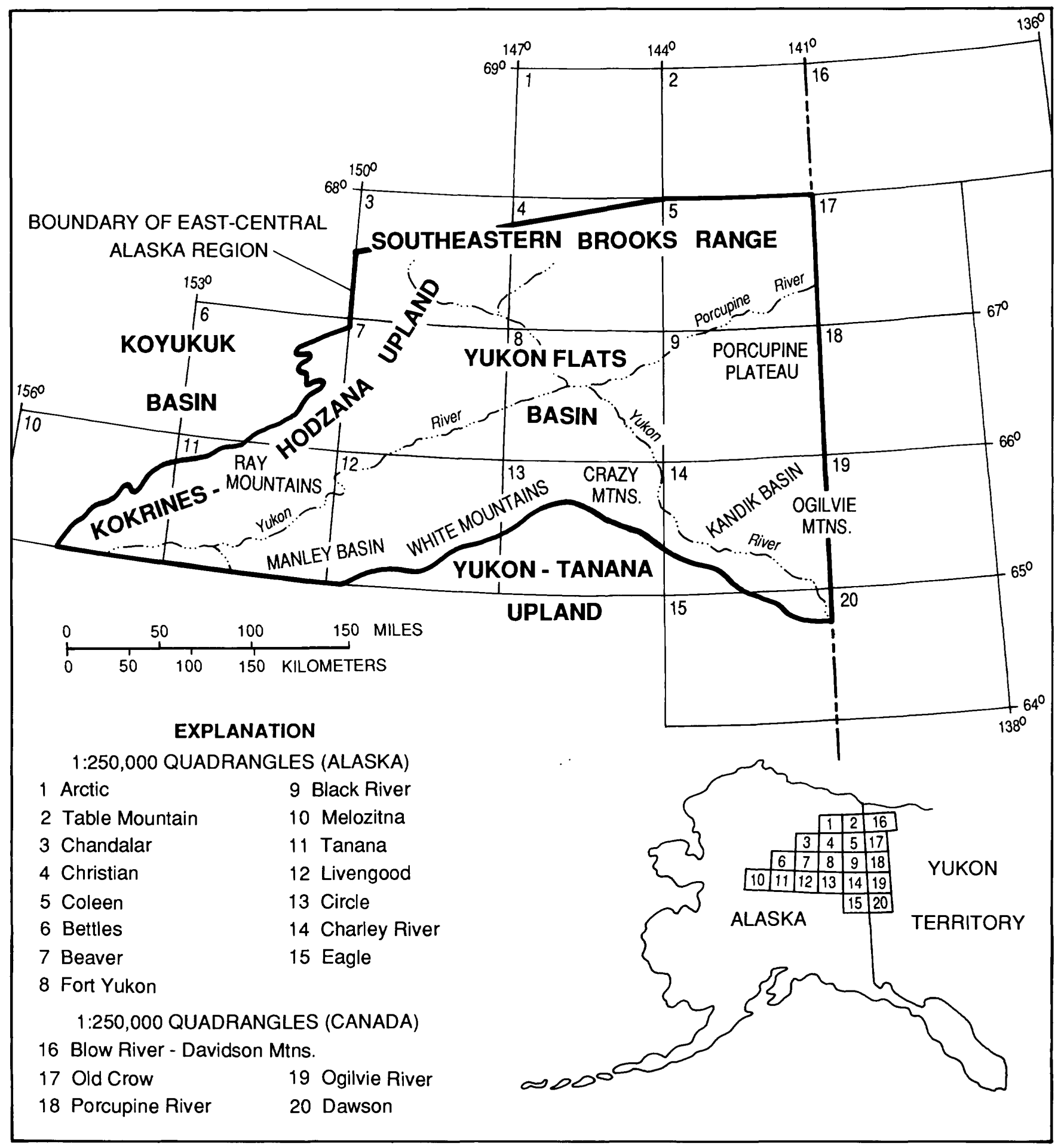

Figure 1. Index map showing area of study, quadrangle locations, and main physiographic features. 


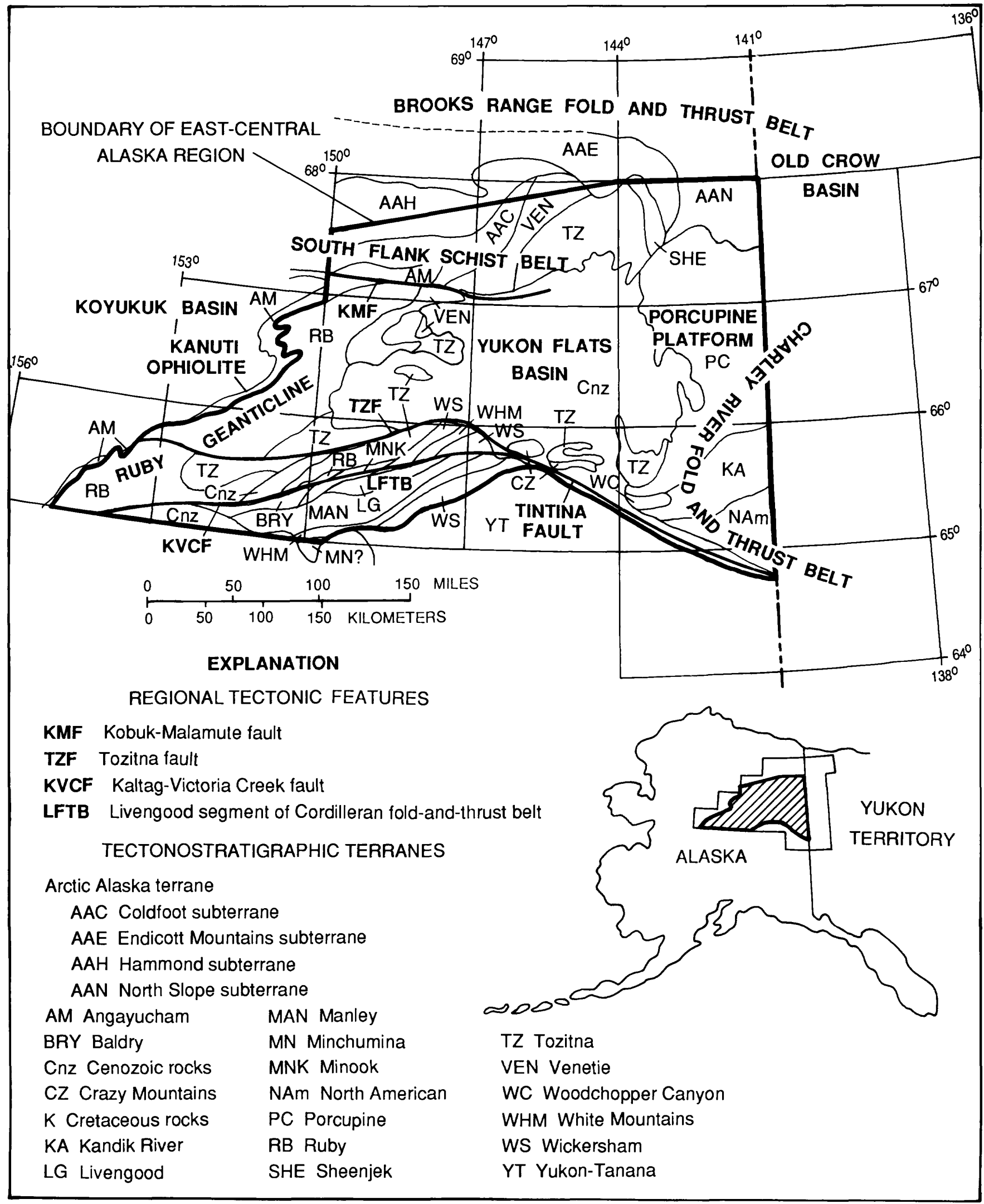

Figure 2. Major geotectonic features and tectonostratigraphic terranes. ${ }^{*}$, terranes after Silberling and others, this volume, Silberling and Jones, 1984, and Churkin and others, 1982) 
(1) How internally consistent and distinct are the stratigraphic and structural frameworks of the terranes previously designated for east-central Alaska? Are there similarities as well as differences among these terranes, and if so, how are they explained?

(2) What is the character of terrane-bounding structures? Can major suture zones be identified in east-central Alaska? If so, how do they relate to other major structural features known in the region, such as fold-and-thrust belt structures or strike-slip faults?

(3) How and where did the ultramafic-bearing mafic volcanic/plutonic sequences of east-central Alaska originate, and how were they emplaced at their present sites?

(4) What is the significance of the granitic plutonism and metamorphic overprint that characterize some terranes, and how distinct are the metamorphic differences between terranes?

(5) Is terrane accretion required to explain the geologic framework of eastcentral Alaska, or can reasonable paleogeographic reconstructions be made for a non-accretionary model of geologic development, as well?

The approach taken in this chapter is first to briefly describe the geology of representative areas within the east-central Alaska region (fig. 3), using newly compiled geologic maps for each of the areas. The areas considered are: (A) Charley River, (B) Livengood, (C) Ray Mountains, (D) Beaver, and (E) Coleen. Each of these areas has undergone recent work or is critically situated with respect to regional geologic problems and lends itself to re-evaluation in light of new studies elsewhere in the region. Together, these five areas encompass most of the bedrock exposed in the east-central Alaska region. Next, important topical problems of regional or interregional significance are discussed within the context of the areal geology as presently understood or interpreted, and the question of terrane accretion is considered. In a brief concluding section, a preferred paleogeographic and geotectonic model is suggested.

\section{GEOLOGIC SUMMARIES OF REPRESENTATIVE AREAS}

\section{Charley River Area}

As defined here, the Charley River area includes the parts of the Charley River and northeast Eagle 1:250,000 quadrangles lying north of the Tintina fault zone (fig. 3). Rocks of the Yukon-Tanana upland south of the Tintina zone are discussed by Foster and others (this volume).

Previous work. Geologic observations were first made in the charley River region by pioneering Alaskan geologists such as Prindle (1905, 1906, 1913), Kindle (1908), Brooks and Kindle (1908), and Cairnes (1914); but the reconnaissance studies of Mertie (1930, 1932, 1937) laid the groundwork for subsequent geologic 


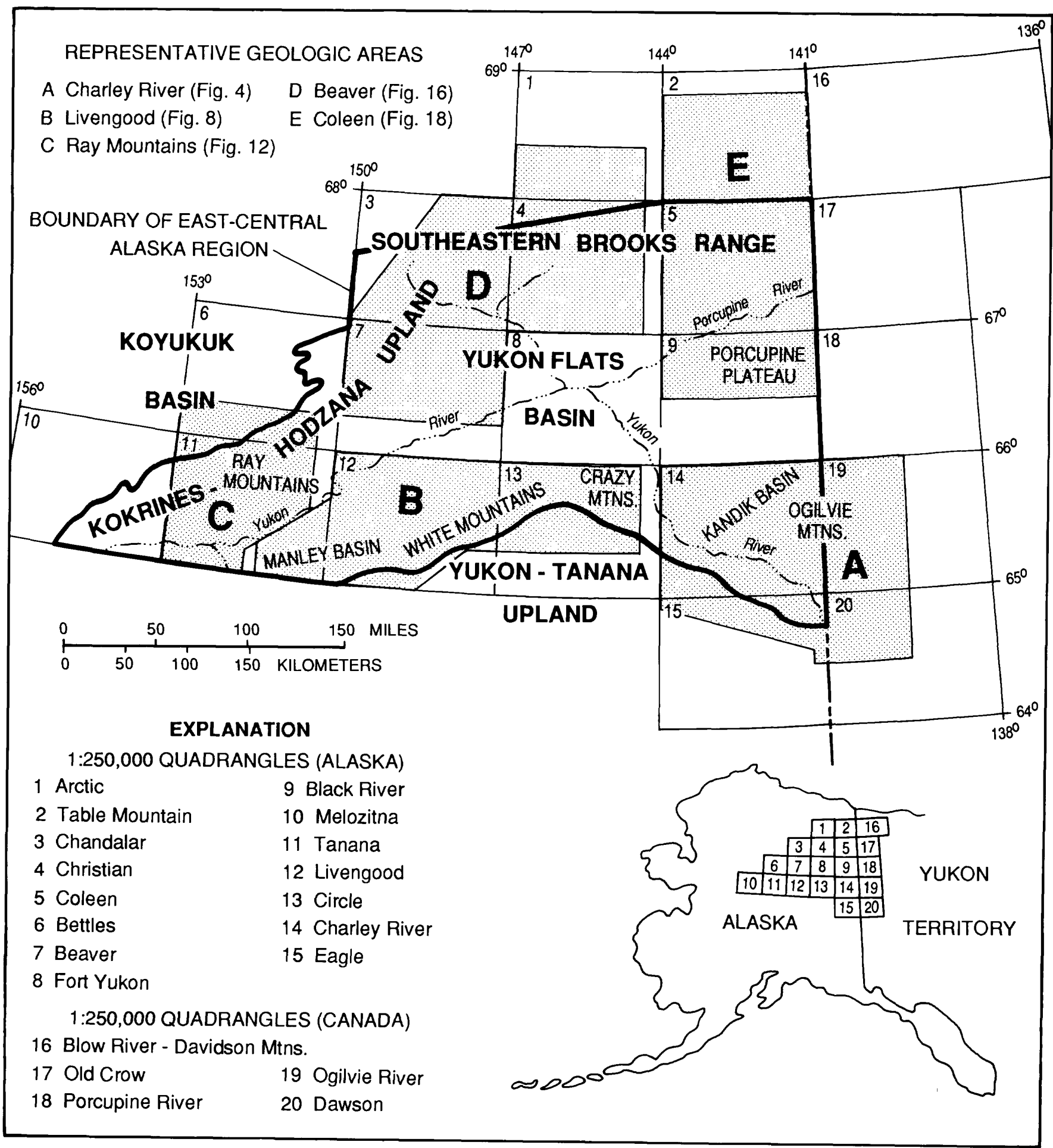

Figure 3. Location of representative geologic map areas discussed in text and illustrated in succeeding figures. 
investigations in this part of east-central Alaska. For the past 20 years, the work of Brabb and Churkin has served as the geologic standard for the Charley River area. Current work relies largely on the distribution of rock units mapped by Brabb and Churkin (1969) and on the stratigraphic relations worked out during the course of their mapping (Brabb, 1967, 1969; Brabb and Churkin, 1967; Churkin and Brabb, 1965a,b). Reconnaissance petroleum and mineral exploration during the past 10 years has led to the realization that thrust faulting was an important deformational mechanism in the Charley River and adjacent areas (Gardner and others, 1984; unpublished data of British Petroleum Corporation and Louisiana Land and Exploration Corporation), and recent work suggests that the area lies within an extension of the northern Cordilleran fold-and-thrust belt of Canada (Dover, 1985a). Norris (1982, 1984) mapped a comparable style of folding and thrusting in adjacent Yukon Territory.

Stratigraphic and structural framework. The most recent map compilations of the Charley River area are those of Dover (1988) and Dover and Miyaoka (in press), shown in simplified form in figure 4. The pattern of distribution of stratigraphic units on the map results from the tectonic repetition of a variety of stratigraphic sequences within a belt of folding and thrusting that extends across the entire Charley River area. The geology of parts of the Dawson and Ogilvie River quadrangles in adjacent Yukon Territory is compiled from Norris (1982) on figure 4 in order to illustrate the regional continuity of stratigraphic and structural trends.

The thrusted stratigraphic sequence in the eastern part of the Charley River area comprises a predominantly carbonate and marine clastic succession as much as $11,000 \mathrm{~m}$ thick of Middle Proterozoic to Early Cretaceous age (fig. 5). Detailed stratigraphic descriptions of the succession can be found in the reports by Brabb and Churkin already listed, and in reports by Clough and Blodgett (1984), Young (1982), and Laudon and others (1966). The three most prominent thrust repetitions involve two key stratigraphic units: (1) Late Proterozoic and(or) Lower Cambrian strata of the upper part of the Tindir Group, which includes oldhamia-bearing beds in two of the repeated sections and basaltic volcanics and redbeds in all three sections, and (2) the Permian Tahkandit Limestone and Triassic limestone and shale of the lower part of the Glenn Shale, also found in all three structurally repeated sections. The moderate- to low-dip of the bounding thrusts can be observed locally in bedrock exposures, but more commonly, it is interpreted from mapped thrust traces. The older-on-younger pattern of thrust repetition required by the map patterns for the main thrust-bounded sequences in the southeastern part of the map is illustrated in the five structure sections shown in figure 6 . Numerous imbricate fault splays complicate the internal structure of each of the thrust-bounded sequences, but the principal sole thrusts are indicated on both the map and the structure sections. The structure sections are constructed from surface geologic controls using classic fold-and-thrust belt styles and geometric rules (see Dover, in press). However, because of limited stratigraphic control, the sections should be considered conceptual rather than balanced.

Map patterns also demonstrate that at least some of the prominent faults in the western Charley River area are older-on-younger thrusts. The Snowy Peak and Threemile Creek thrusts, for example, bring late Paleozoic or older strata over Lower Cretaceous rocks of the Kandik Group (fig. 4). However, in contrast to the 


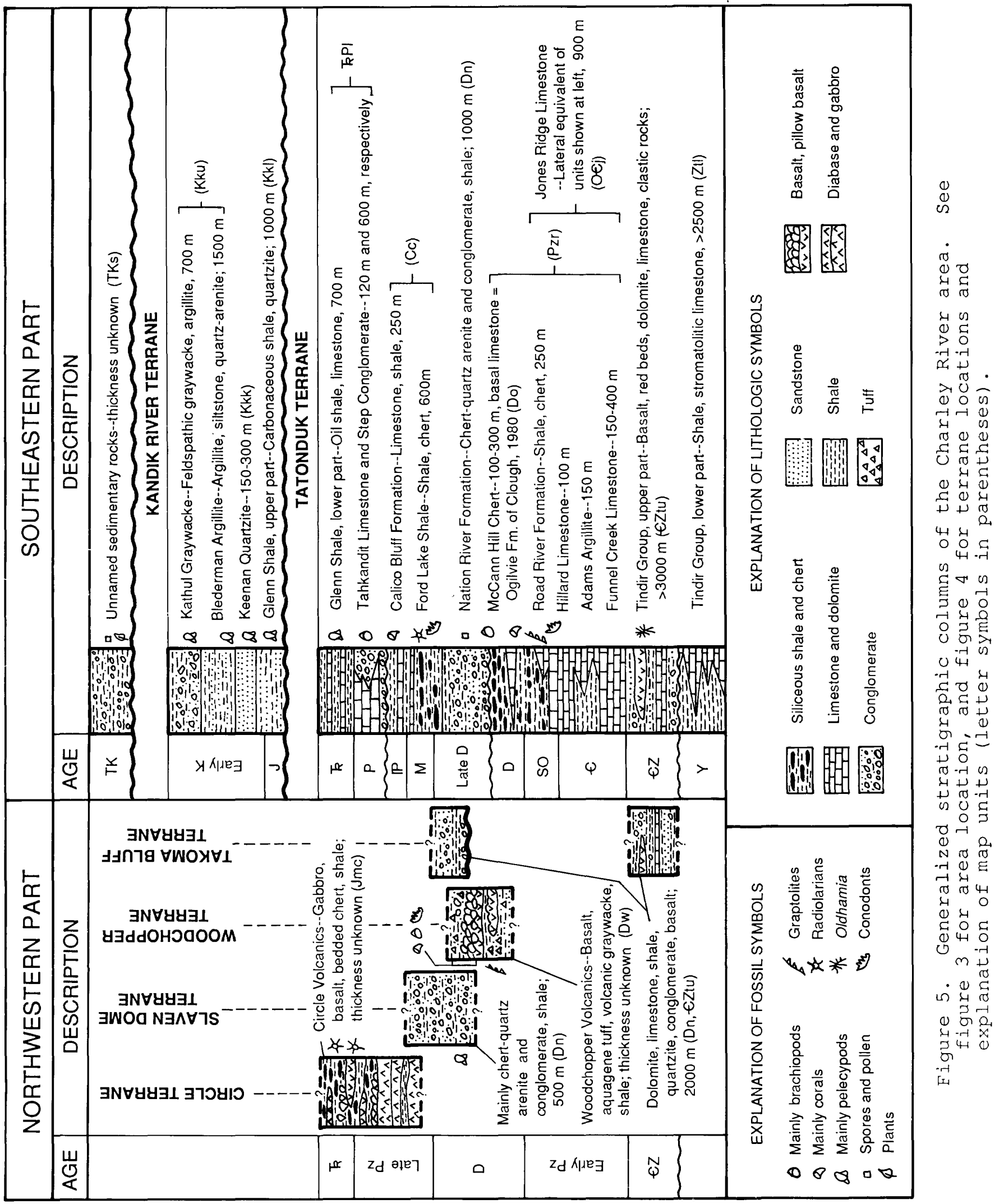




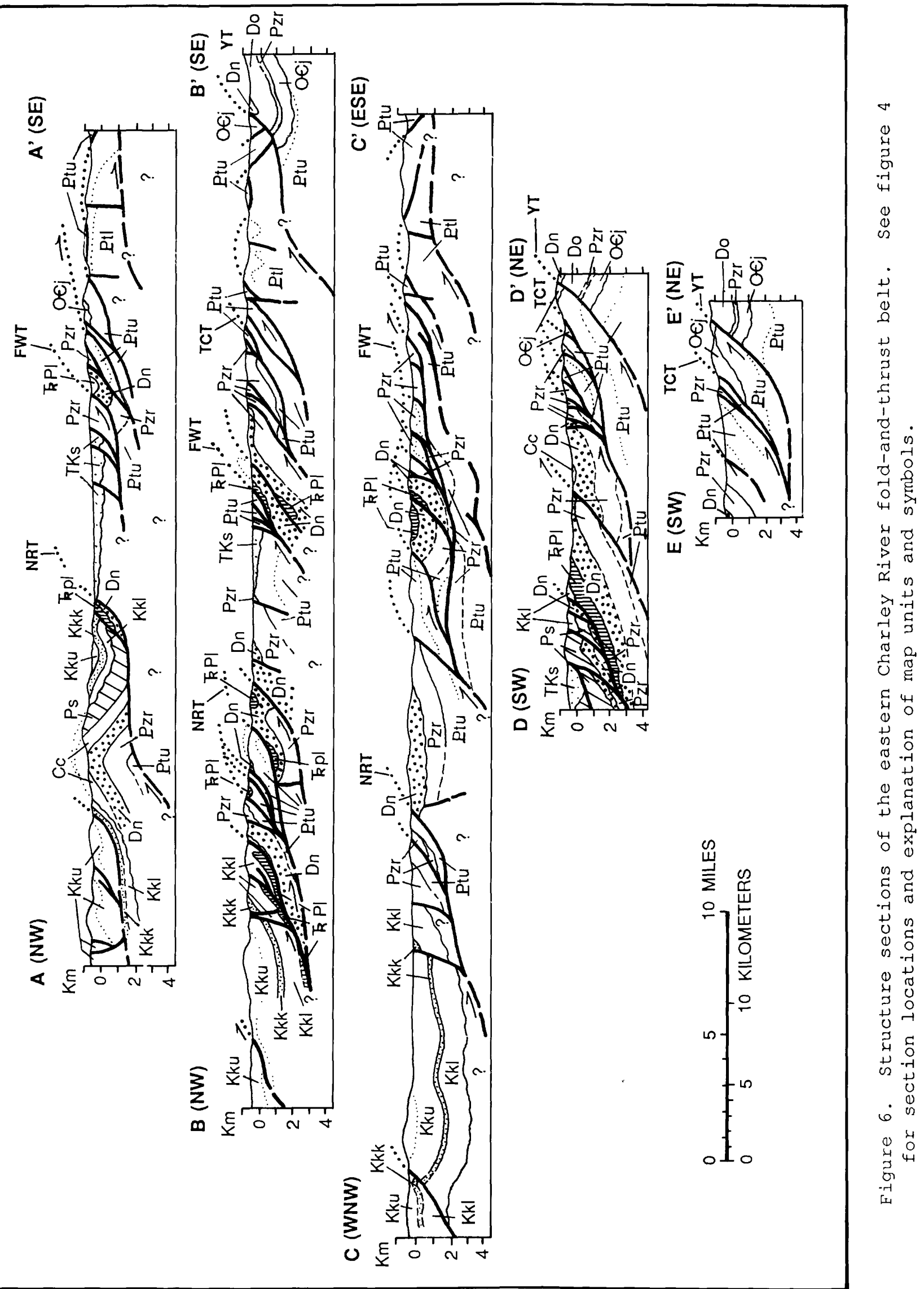


eastern part of the Charley River area, the stratigraphic sequences involved in thrusting in the western part are mainly clastic rocks, bedded chert, and associated mafic igneous rocks of early, middle, and late Paleozoic, and Mesozoic ages (fig. 5). The drastic lithologic differences between these sequences and coeval ones in the eastern part of the Charley River area led to Jones and others (1981) and Churkin and others (1982) designate these western sequences as separate tectonostratigraphic terranes. Although some of these terranes are bounded by thrust faults comparable in style and magnitude to those elsewhere in the foldand-thrust belt of the Charley River area, the character of the bounding structures of the rest of these terranes is equivocal because of poor exposures.

Stratigraphic variations in the Charley River fold-and-thrust belt--Although the stratigraphic succession involved in the eastern part of the Charley River fold-and-thrust belt is generally the one defined by Brabb and Churkin, numerous differences occur in the successions of various thrust plates (fig. 7) as a result of facies variations and several major unconformities (see fig. 5 and discussion by Dover, in press). Variations occur along strike within individual thrust plates as well as between different thrust plates. For example, the predominant carbonate and quartzite-argillite components of the upper part of the Tindir Group, as well as subordinate interlayers of chert-clast conglomerate, diamictite, redbeds, and basaltic volcanic and volcaniclastic rocks, interfinger within the Yukon and Three Castle Mountain thrust plates (figs. 4 and 7). One example of facies telescoped across a thrust boundary involves the Jones Ridge Limestone and coeval but more argillaceous Ordovician to Cambrian strata across the Tatonduk thrust. Another example is the variations in limestone and chert-clast conglomerate components between the Permian Tahkandit Limestone and Step Conglomerate that occur in thrust slices of the Nation River thrust system (figs. 4 and 7). Thrusting also juxtaposed sequences in which different amounts of section are missing beneath at least four major unconformities that punctuate the Middle Proterozoic to Lower Cretaceous succession of the eastern part of the Charley River area (see fig. 5). The unconformities are: (1) between the upper (Lower Cambrian and(or) Late Proterozoic) and lower (Middle Proterozoic) parts of the Tindir Group, (2) below the Nation River Formation (Upper Devonian), (3) below the Tahkandit Limestone and Step Conglomerate (Permian), and (4) between the upper (Lower Cretaceous and Jurassic) and lower (Middle and Upper Triassic) parts of the Glenn Shale. The most drastic and abrupt differences are in the amount of section missing beneath the unconformity at the base of the Permian section, which rests directly on upper Tindir strata in the Nation River thrust complex (figs. 4 and 7). Figure 7 represents a preliminary attempt to reconstruct facies patterns prior to thrusting across the southeastern part of the thrust belt. Little is known about facies variations and unconformities within the stratigraphic sequences of the western part of the Charley River fold-and-thrust belt.

Direction and amount of tectonic transport--Most thrusts in the Charley River quadrangle have northeast trends and underwent tectonic transport toward the southeast, based on the trends of thrust-generated folds, regional dips, and gross map patterns of older-on-younger stratigraphic repetition (see fig. 4). Most major folds are upright, but a few are overturned in the direction of tectonic transport. A few northwest-directed back-thrusts are inferred in places, and some have been mapped by Norris (1982) in adjacent Yukon Territory. On the other hand, thrusts in the southeast corner of the Charley River quadrangle and in the 


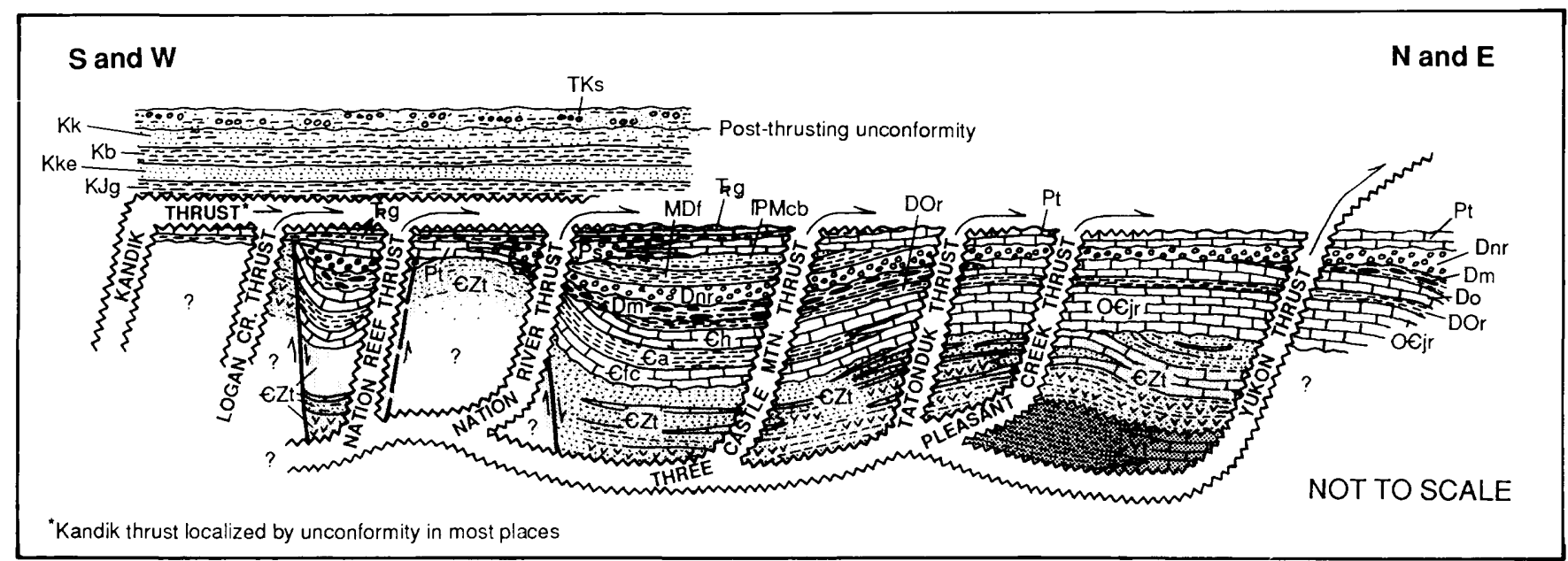

Figure 7. Schematic pre-Jurassic stratigraphic relations interpreted from restored thrust plates, eastern Charley River fold-and-thrust belt. See figure 4 for explanation of map units and figure 5 for explanation of lithologic symbols. 
northeast Eagle quadrangle trend predominantly northwest-southeast parallel to structures in the adjacent Dawson quadrangle of Yukon Territory, where the direction of tectonic transport is toward the northeast, based on the same kinds of map evidence mentioned above. The remarkable change of 90-110 degrees in orientation of the Charley River fold-and-thrust belt involves direction of transport as well as structural trend, and takes place at an abrupt "bend" around which individual structures can be mapped continuously from one trend to the other. The axis of the bend generally coincides with the Michigan Creek and other major anticlines in the Charley River map area, and projects eastward into a narrow zone separating belts of east-west and north-northeast structural trends in adjacent Yukon Territory (fig. 4).

Modest amounts of thrust transport, generally of $5 \mathrm{~km}$ or less, are interpreted for most individual thrust plates from the geometric constraints of cross-section construction; total shortening distributed within some structural duplexes or imbricate thrust zones may be $10 \mathrm{~km}$ or more. Cumulative shortening of $100 \mathrm{~km}$ is estimated for the segment of the Charley River fold-and-thrust belt in the Charley River area.

Numerous listric normal faults are shown on figure 4. These faults generally involve Lower Cretaceous rocks of the Kandik Group and Upper Cretaceous to Tertiary rocks; in places the listric faults involve older rocks as well. The listric faults are interpreted to splay from relatively steep-dipping segments of thrust faults, where the thrusts are inferred to ramp upsection. As a corollary, ramps were suspected in cross-section construction below areas of abundant listric normal faulting (fig. 6).

Timing of fold-and-thrust belt deformation--Lower Cretaceous rocks are involved in folding and thrusting throughout the Charley River region. There is no positive evidence to suggest compressional deformation prior to the Albian (Early Cretaceous) in the Charley River fold-and-thrust belt, but that possibility cannot be eliminated. Less deformed rocks of Late Cretaceous (Maestrichtian?) to mid-Paleocene age (unit TKs) unconformably overlap and post-date folding and thrusting (fig. 4). In the two places where previous mapping suggested that Late Cretaceous to Tertiary were involved in thrusting, new evidence for an Early Cretaceous age of the deformed rocks has been found (Dover, in press; Cushing and others, 1986). Therefore, at least the latest, and probably the main stage of fold-and-thrust belt development occurred after deposition of the Albian Kathul Graywacke and correlative rocks, and before unconformable deposition of unit TKs began in Maestrichtian? time. The same age of deformation is indicated for all parts of the Charley River fold-and-thrust belt, regardless of structural trend and direction of thrust transport.

Listric normal faulting involving Upper Cretaceous and Tertiary strata as young as Eocene(?) post-dates compressional deformation.

Tintina fault zone--The Tintina fault zone cuts northwest-southeast across the southwest corner of the Charley River area. It separates weakly to nonmetamorphosed rocks of the Charley River fold-and-thrust belt, on the north, from igneous and metamorphic rocks of the Yukon-Tanana upland (see Foster and others, 1987, and this volume), to the south. The Tintina zone is expressed 
topographically as a linear trench, which contains Upper Cretaceous to lower Tertiary non-marine clastic sedimentary rocks and(or) Cenozoic sediments. It is a major strike-slip zone along which significant right-lateral strike-separation occurred prior to Late Cretaceous and younger deposition; $450 \mathrm{~km}$ of rightseparation is documented in southern Yukon Territory (Tempelman-Kluit, 1979; Gordey, 1981). Although the magnitude of strike-slip that has occurred along the part of the Tintina fault zone in the Charley River area cannot be demonstrated locally, the Tintina zone's distinctly cross-cutting relation to the Charley River fold-and-thrust belt is evident from map patterns. Locally in the Charley River area, fold-and-thrust belt structures appear to be dextrally dragged as much as a few ten's of kilometers along the Tintina zone.

Tintina trench-fill deposits are cut by an array of mainly dip-slip or oblique-slip faults--some with substantial displacements that accompanied uplift of the Yukon-Tanana block south of the Tintina zone. Some of these faults are still active (Foster and others, 1983). As much as $50 \mathrm{~km}$ of cumulative postEocene strike-separation is inferred for faults cutting Tintina trench-fill in Yukon Territory (see Hughes and Long, 1979,) and in the Eagle quadrangle (Barker, 1986; Cushing and others, 1986), suggesting reactivation or continuation of Tintina strike-slip motion into post-Eocene time.

\section{Livengood area}

As defined here, the Livengood area includes most of the Livengood 1:250,000 quadrangle, as well as the part of the southeast Tanana quadrangle south of the Yukon River, and the Crazy Mountains and adjacent parts of the northern Circle quadrangle (fig. 3). The area excludes the Yukon-Tanana upland, described by Foster and others (this volume).

Previous work. Geologic investigations prior to 1935 in the Livengood area by Prindle, Brooks, and Eakin, are summarized and incorporated by Mertie (1937) in his geologic description of the Yukon-Tanana region. Much of the impetus for those and subsequent geologic studies in the area was the discovery of gold and the development of placer mines, many of which have operated intermittently to the present time. Regional map compilations $(1: 250,000)$ by Chapman and others (1971, 1982) and Foster and others (1983) serve as a basis for current studies in the Livengood area. Reports of particular interest include those by Foster (1968), Brosgè and others (1969), Davies (1972), Chapman and others (1979), Foster and others (1982), Weber and Foster (1982), Albanese (1983), Cady and Weber (1983), Robinson (1983), Smith (1983), Cushing and Foster (1984), Weber and others (1985), Blodgett and others (1987), Wheeler-Crowder and others (1987), and Weber and others (1988).

Stratigraphic and structural framework. The degree of structural segmentation of the Livengood area and the complexity of its disrupted stratigraphy are clear from published geologic maps of the area, and are inherent in its subdivision into numerous tectonostratigraphic (lithotectonic) terranes by Churkin and others (1982), Silberling and Jones (1984), and Silberling and others (this volume). However, the actual character and regional significance of this 
geologic framework are not as obvious. In this summary, the geology of this critically situated area is updated in light of new data and work in progress.

Stratigraphic belts and terranes--The Livengood area contains eleven distinct stratigraphic belts** that are separated structurally from one another (fig. 8 ). The bounding structures of the belts are either strike-slip faults or thrust faults, but which of these types of fault is represented by individual structural boundaries has been in question. The geologic map of figure 8 shows my preferred structural interpretation of the Livengood area. This interpretation differs in some important details from previously published map interpretations, reflecting the uncertainty of some field relations. However, there is general agreement on the character of the fault-bounded stratigraphic belts (fig. 9).

(1) The Wickersham stratigraphic belt, called the Wickersham terrane by Silberling and Jones (1984) and the Beaver terrane by Churkin and others (1982), is the southeasternmost and structurally highest of the stratigraphic belts. It consists of the informally named Wickersham grit unit of Late Proterozoic and Early Cambrian age (Weber and others, 1985). The wickersham grit unit is subdivided by Chapman and others (1971) into a lower part of rhythmically interbedded grit, bimodal quartzite, slaty argillite, and subordinate chert and maroon and green slate, and an upper part of slaty argillite, maroon and green slate, quartzite, black limestone containing floating quartz grains, chert, and subordinate grit. The grit unit is overthrust from the southeast by greenschist facies metamorphic rocks of the Yukon-Tanana upland, thought by weber and others (1985) to be only modestly telescoped and slightly higher grade equivalents of the grit unit.

(2) The White Mountains stratigraphic belt, called the White Mountains terrane by Silberling and Jones (1984) and Churkin and others (1982), is characterized by the Fossil Creek Volcanics (Ordovician) and the disconformably overlying Tolovana Limestone (Silurian). The Fossil Creek Volcanics is agglomeratic and has an alkalic basaltic composition. Recent mapping shows that (1) the sedimentary and volcanic divisions of the Fossil Creek recognized by Chapman and others (1971) are interfingering lateral facies rather than vertically stacked units, and (2) the Fossil Creek volcanics were deposited on a basement of upper Wickersham grit unit that is identical in all respects to the grit unit in the wickersham belt. Moreover, pebbles and cobbles of gritty quartzite resembling the wickersham grit unit occur in the agglomeratic volcanic part of the Fossil Creek, indicating a nearby source of wickersham rocks in Ordovician time. The character and distribution of Fossil Creek lithologies and their basaltic

\footnotetext{
** The term "stratigraphic belt" is used here to denote a typically elongate belt of rocks having characteristic stratigraphy or lithologic content that differs in some way from that of adjacent belts. This term is used in order to avoid any genetic connotation of "suspect" or accretionary origin that may be associated with the terms "tectonostratigraphic terrane" and "lithotectonic terrane", either by intent or by implication of common usage (for example, see usage in silberling and Jones, 1984, P. A-2; and AGI Glossary, Bates and Jackson, 1987).
} 


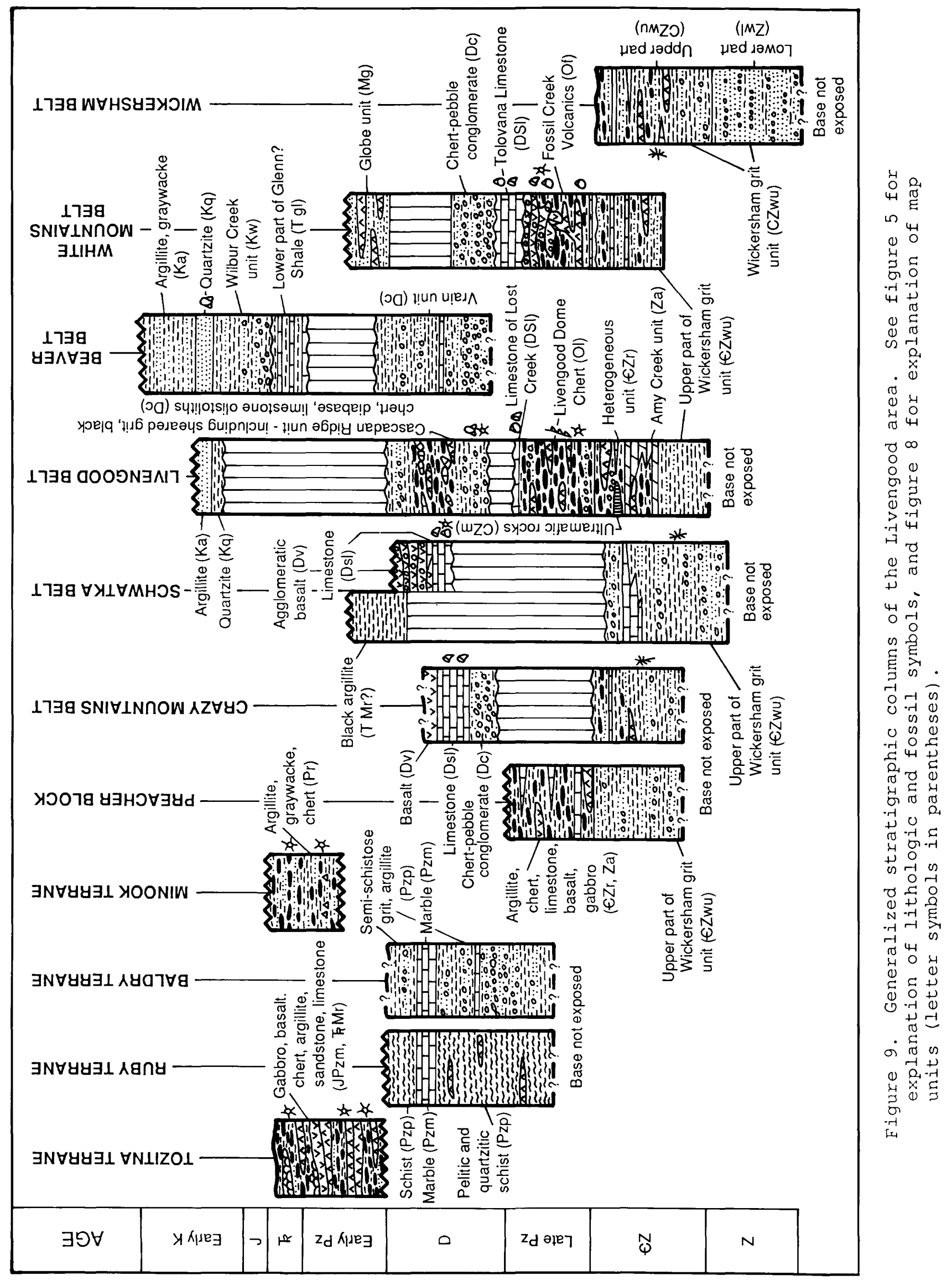


composition suggest a local volcanic center within an intracontinental depositional basin with locally steep, perhaps fault-controlled topography. From these lithologic relations and from map evidence for structural overturning and discordance, the boundary between the white Mountains and Wickersham/Beaver terranes is interpreted to be a thrusted unconformity of relatively small displacement.

Locally, chert- and quartzite-clast conglomerate and associated clastic rocks unconformably overlie the Fossil Creek-Tolovana section. The conglomerate is undated but is lithologically similar to that in the Nation River Formation (Devonian) and the Step Conglomerate (Permian) of the Charley River area.

Also included here in the White Mountains stratigraphic belt, but detached from the Fossil Creek-Tolovana section by another thrust fault, is a distinctive unit of gray, commonly bimodal, vitreous quartzite referred to as the Globe unit by Weber and others (1985). The Globe unit typically contains sheared argillite interbeds and abundant sills of hornblende-bearing quartz diorite or quartz gabbro. The age of this quartzite is unknown, and so far, the mafic intrusive rocks have proved too altered to date. However, the vitreous and bimodal character of the Globe unit, and its association with mafic sills, serve to distinguish it from other quartzites of the Livengood area. The Globe unit at the base of the White Mountains belt is in steep- to moderate-angle thrust contact on the Beaver Creek stratigraphic belt to the north.

(3) The Beaver Creek stratigraphic belt corresponds to the Manley terrane of Silberling and Jones (1984) and part of the Kandik terrane of Churkin and others (1982). The Beaver Creek belt contains mainly flyschoid rocks and chert-rich, locally derived polymictic conglomerate. There are three distinct flysch sequences in the Beaver Creek belt. The Vrain unit of Foster and others (1983) occurs in the eastern part of the belt, the wilber Creek unit of Weber and others (1985) has been mapped mainly in the central and western parts of the belt, and the Cascaden Ridge unit of Weber and others (1985) occurs in the central part of the belt along its north edge.

The Vrain unit, which is undated, consists mainly of carbonaceous, commonly iron-stained, rhythmically interlayered fine-grained to gritty clastic rocks, as well as tuff, and a prominent unit of typically stretched chert- and quartzitepebble conglomerate. Minor amounts of chert and basalt also occur in rocks questionably assigned to the Vrain.

The Middle Devonian (Eifelian) Cascaden Ridge unit consists mainly of turbiditic shale, quartzite, and conglomerate. It has a locally developed basal conglomerate containing up to cobble- or boulder-sized clasts of mafic/ultramafic rocks, chert, dolomite, shale, and other locally occurring rock types (Weber and others, 1985). The similarity of some characteristic lithic components of the Cascaden Ridge and Vrain units, and their comparable stratigraphic position between the Wilber Creek unit and a persistent mafic/ultramafic band at the top of the underlying Livengood stratigraphic belt, raises the possibility that the Cascaden Ridge and Vrain units may be correlative, at least in part. 
The Wilber Creek unit is Late Jurassic and Early Cretaceous in age, and contains shale, graywacke, quartzite, and polymictic conglomerate. It probably lies unconformably on both the Vrain and Cascaden Ridge units, but its basal contact is poorly constrained and questionably located on figure 8 because of the difficulty in distinguishing between these three flysch units.

Polymictic conglomerates tentatively assigned to the Cascaden Ridge, Vrain, and Wilber Creek units of the Beaver Creek stratigraphic belt contain locally derived chert, argillite, quartzite, carbonate, mafic volcanic, and low-grade metamorphic clasts, and flat shale chips, as well as quartz, plagioclase, muscovite, chlorite, epidote, and opaque grains. All of these constituents are present in the various rock sequences of the Livengood area, suggesting that these polymictic conglomerates were derived from local sources as early as Middle Devonian time. All three of the flysch units appear to be in faulted or faulted unconformable contact on the Livengood stratigraphic belt to the north.

Some of the clastic rocks formerly mapped as wilber Creek unit in the Serpentine Ridge and Manley areas of the southeastern Tanana quadrangle (labeled $\mathrm{SR}$ and $\mathrm{M}$, respectively, on figure 8 ) are inferred here to be pre-Cretaceous based on lithologic associations and degree of induration.

An undated sequence of dark-gray calcareous shale, silty limestone, and subordinate quartzite, tentatively correlated with the lithologically similar lower part of the Glenn Shale (Triassic) in the Charley River area, also occurs locally in the Beaver Creek stratigraphic belt.

(4) The Livengood stratigraphic belt generally corresponds with the Livengood terrane of Silberling and Jones (1984) and Churkin and others (1982). The Livengood belt is characterized by the Livengood Dome Chert (Ordovician), which in its type area consists mainly of intensely deformed black to varicolored chert and subordinate interbeds of graptolitic shale, tuffaceous rocks, and limestone. In some places, mafic sills or basalt interbeds occur in the Livengood Dome Chert. The Livengood Dome Chert could be a less volcanic facies of the Ordovician Fossil Creek Volcanics, which contains dark chert interbeds in the white Mountains stratigraphic belt.

Many questions have arisen about the stratigraphic and structural relations of the Livengood Dome Chert with other units of the Livengood stratigraphic belt, because most of the units are poorly dated and contacts are seldom exposed. Uncertain identification of two key units is especially critical to map interpretation in the central and eastern parts of the livengood belt. The two units are a distinctive dolomite, called the Amy Creek unit (Weber and others, 1985), and a clastic unit characterized by chert-pebble conglomerate (mapped as $\mathrm{Za}$ and Dc, respectively, on figure 8 ).

The Amy Creek unit is a silicified, locally stromatolitic dolostone formed largely by dolomitization of pelletoidal lime mud. It contains thick black chert interbeds and lesser amounts of argillite, basalt, and volcaniclastic rocks. The Devonian to Silurian age originally assigned to the Amy Creek unit was based on fossils in a thin, presumably correlative limestone bed at a fossil locality on Lost Creek (locality A, fig. 8). However, that correlation is now discounted, and 
the Amy Creek unit is currently undated (Robert Blodgett, oral commun., 1987). Based on its lithologic and petrologic character, and on its lack of fossils, the Amy Creek unit more closely resembles Late Proterozoic dolomites of the eastcentral Alaska region and Yukon Territory than a middle Paleozoic carbonate. A Late Proterozoic age is therefore tentatively adopted for the Amy Creek unit in this report for map and interpretive stratigraphic purposes. The fossiliferous Lost Creek beds are now designated as a separate unit of Late Silurian age, informally named the limestone of Lost Creek (see figures 8 and 9), that lies stratigraphically between the Livengood Dome Chert and a unit of chert-pebble conglomerate (Blodgett and others, 1988).

Chert-pebble conglomerate commonly occurs as isolated exposures between outcrops of the Livengood Dome Chert and maroon and green slate characteristic of the upper part of the Wickersham grit unit. At locality B, north of Livengood Dome (fig. 8), where the conglomerate contains flat argillite chips and has an amorphous siliceous matrix, it has been interpreted as a basal conglomerate of the Livengood Dome Chert (Weber and others, 1985). At locality C (fig. 8), chertpebble conglomerate occupies a similar position between the Livengood Dome Chert and the maroon and green slate unit, but here the conglomerate also contains granular dolomite clasts, is associated with black argillite, graywacke, and other clastic rocks, and has a mylonitic quartz-chert arenite matrix. In the character of its matrix and associated rocks, this conglomerate more closely resembles conglomerates assigned to middle Paleozoic or younger clastic sequences in the Beaver Creek stratigraphic belt. The tentative interpretation, shown on figure 8 , is that the chert-pebble conglomerate at localities $B$ and $C$ is part of a Devonian clastic sequence lying in angular unconformity on the upper wickersham grit unit and overthrust by the Livengood Dome Chert.

East of locality $C$, the same conglomerate appears to lie in low-angle unconformity across a contact between maroon and green slate assigned to the upper part of the Wickersham grit unit, and a heterogeneous overlying unit of chert, siliceous argillite, greenstone, agglomeratic basalt, dolomite, dolomite-boulder conglomerate, siltite, quartzite, grit, and felsic volcanics?, all injected by abundant, thick mafic sills. The sills range from quartz-bearing diorite and gabbro to sparse serpentinized cumulate ultramafic rocks thought to be differentiates of the sills.

The mafic and ultramafic rocks of the heterogeneous unit are similar in composition and petrologic character to those in a persistent but discontinuous northeast-trending band that marks the structural top of the Livengood stratigraphic belt. The rocks within this band include gabbro and diorite interlayered with serpentinized peridotite and dunite. $\mathrm{K}$-Ar hornblende ages on three diorite or gabbro samples from this band near Amy Dome give Cambrian to Late Proterozoic ages ranging from $518.3 \pm 15.5$ to $633 \pm 19 \mathrm{Ma}$ (D.L. Turner, unpublished data). Modeling of gravity and magnetic data across the mafic/ultramafic band confirms its layered character and the southward-decreasing dip of its structural base (Cady and Morin, in press). The origin of these rocks is uncertain, but they are tentatively interpreted as a differentiated Cambrian or Precambrian sill complex by Cady and Morin (in press). Based on their lithologic associations and the petrologic similarties of their mafic and ultramafic components, the heterogeneous unit, the Amy Creek unit, and the mafic/ultramafic band of the 
Livengood stratigraphic belt may all represent thrust segments of a volcanic/plutonic center correlative with the upper part of the Tindir Group in the Charley River area, and the Mount Harper Volcanic complex in the Dawson area of Yukon Territory.

(5) The Schwatka stratigraphic belt is separated from the Livengood belt by the Victoria Creek strike-slip fault. The Schwatka belt has been included in the Wickersham and White Mountains terranes by Silberling and Jones (1984), and in the corresponding Beaver and White Mountains terranes by Churkin and others (1982). Oldhamia-bearing wickersham grit unit forms the basement of the Schwatka stratigraphic belt, but recent work indicates that overlying clastic, volcanic, and carbonate rocks differ from those of the white Mountains stratigraphic belt. Fossiliferous Lower Devonian (Emsian) and(or) Middle Devonian (Eifelian) limestone in the Schwatka belt is distinctly younger than the Silurian Tolovana Limestone of the White Mountains, with which it was formerly correlated (Weber and others, 1988). If some of the limestone of the Schwatka belt is interbedded with the underlying unit of agglomeratic mafic volcanics, chert, and clastic rocks, as preliminary interpretation of recent mapping suggests, then at least part of the volcanic-bearing sequence may be as young as Early or Middle Devonian. If so, these volcanic rocks would be at least partly correlative with the Woodchopper Volcanics of the Charley River area, rather than with the Fossil Creek Volcanics of the White Mountains. This interpretation supports that originally made by Mertie (1937).

(6) The Crazy Mountains belt is separated from the rest of the Livengood area by strike-slip faults. Most of the rocks in the East and West Crazy Mountains are included in the Crazy Mountains terrane of Silberling and Jones (1984) and Churkin and others (1982). The upper part of the wickersham grit unit forms the basement of the Crazy Mountains belt, where maroon and green slate, grit, and black limestone containing floating quartz grains are distinctive lithic components, and the section contains oldhamia. Lithologies in the structurally? overlying sequence of chert, clastic rocks, mafic igneous rocks, and fossiliferous Lower Devonian limestone resemble those in the Schwatka stratigraphic belt. Overlying chert-pebble conglomerate is indistinguishable from middle to upper Paleozoic conglomerates in the White Mountains, Beaver Creek, and Livengood stratigraphic belts, and in the Charley River area.

(7) The Preacher block of Foster and others (1983) is bounded by splays of the Tintina strike-slip fault system. It contains thrust imbrications of lithologic components found mainly in the Livengood stratigraphic belt south of the Victoria Creek fault, including rocks of the upper part of the Wickersham grit unit, and probable correlatives of the Amy Creek dolomite unit and the heterogeneous mafic-bearing sequence.

Three additional terranes of small size are defined by Silberling and Jones (1984) at the west end of the Livengood area.

(8) The Minook terrane of Silberling and Jones (1984) contains upper Paleozoic flysch and chert-pebble conglomerate and grit, lithologies resembling those in the Beaver Creek stratigraphic belt. 
(9) The Baldry terrane has been described as a "structurally complex and polymetamorphosed assemblage of radiolarian chert, marble, greenschist, and mica schist" derived from probable lower to middle Paleozoic protoliths (Silberling and Jones, 1984). Although the metamorphic rocks of the Baldry terrane were tightly folded, thrusted, and sheared under low-grade ductile conditions, suitable protoliths occur in the White Mountains, Livengood, and Schwatka stratigraphic belts. Metamorphic recrystallization and ductile deformation in the Baldry terrane could be interpreted as a deeper crustal or higher temperature manifestation of the more brittle style of imbricate thrusting that characterizes the likely protoliths.

(10) The Ruby terrane of Silberling and Jones (1984) also contains metamorphic rocks, but generally of higher grade than those in the Baldry terrane. The principal units are staurolite- and garnet-mica schist and marble. The rocks of the Ruby terrane are described more fully in the section on the Ray Mountains area, to follow. However, by analogy with similar rocks in the Ray Mountains area, where metamorphic facies gradations are abrupt and related to granitic intrusives, the rocks of the Ruby terrane are tentatively interpreted as locally higher grade recrystallized equivalents of protoliths similar to those inferred for the Baldry terrane.

(11) The Tozitna stratigraphic belt, found along the north margin of the Livengood area, is included in the Tozitna terrane of Silberling and Jones (1984) and the Tozitna/Circle terranes of Churkin and others (1982). The Tozitna belt contains the Rampart Group (Brosgè and others, 1969) as well as voluminous mafic intrusive rocks and subordinate basaltic volcanics. The Rampart Group consists of intercalated chert, siliceous argillite, tuffaceous and volcaniclastic rocks, siltstone, sandstone, quartzite, and minor limestone. The mafic rocks, which may constitute 75 percent or more of the Tozitna belt, are dominantly diabase and gabbro, but range from diorite to basalt and pillow basalt. Cumulate ultramafic layers and lenses formed locally, most likely in differentiated sills. The gabbro has a $\mathrm{K}-\mathrm{Ar}$ hornblende age of $210 \pm 6 \mathrm{Ma}$ (Triassic) according to Patton and others (1977). Cherts yield Late Mississippian, Pennsylvanian, and Triassic radiolarians (Foster and others, 1983; Jones and others, 1984), and a limestone bed near Rampart contains Permian fossils (Brosgè and others, 1969). The basal contact between the Tozitna belt and various underlying sequences, including those of the Schwatka and Crazy Mountains stratigraphic belts and the Ruby terrane, is interpreted to be a structural detachment. The content and contact relations of the Tozitna stratigraphic belt are considered further in the summary of the Ray Mountains area to follow.

Granitic intrusive rocks--Granitic plutons of mid-Cretaceous and Early Tertiary age occur in the Livengood area. The oldest dated plutons have midCretaceous $\mathrm{K}-\mathrm{Ar}$ biotite and $\mathrm{Pb}-\mathrm{a}$ zircon ages of about $90 \mathrm{Ma}$ (Chapman and others, 1971, 1982). Two of these are the Roughtop and Sawtooth Mountain plutons, near the north edge of the Beaver Creek stratigraphic belt in the western part of the Livengood area. A third is a small syenitic plug that is enriched in thorium and rare earth elements and occurs within the Wickersham stratigraphic belt. All other dated plutons in the Livengood area give early Tertiary $\mathrm{K}-\mathrm{Ar}$ biotite ages between 55 and $65 \mathrm{Ma}$ (Chapman and others, 1971, 1982; Foster and others, 1983). Three of the early Tertiary plutons--the Manley Hot Springs Dome, Tolovana Hot 
Springs Dome, and Victoria Mountains plutons, intrude flyschoid rocks of the Beaver Creek stratigraphic belt. The two largest of the early Tertiary plutons-the Cache Mountain and Lime Peak plutons, are emplaced in grit of the Wickersham stratigraphic belt. The granitic plutons of the Livengood area are discussed in more detail by Weber and others (1988, p. 30-35) and by Burns and others (1987).

Structure--The keys to recognizing demonstrable strike-slip faults in the Livengood area are (1) their curvilinear topographic expression and continuity across diverse geologic belts, and (2) the width, intensity, and character of shearing of the fault zones. Two principal strike-slip faults are identified in the Livengood quadrangle--the Victoria Creek and Tozitna faults. These are the two main splays of the Tintina fault zone, which enters the Livengood area from the east. The Victoria Creek fault connects westward with the Kaltag fault of the Tanana quadrangle.

Exposures of strike-slip zones are rare because their sheared rocks are weak, easily eroded, and form linear topographic trenches containing valley fill materials. However, the Victoria Creek fault zone is well-exposed along the lower reaches of Victoria Creek. Here, the main part of the fault zone is 1 to $1.5 \mathrm{~km}$ wide and contains disconnected tectonic lenses within an intensely and pervasively sheared, mylonitic matrix. Tectonic lenses range from nearly microscopic in size to blocks hundreds of meters long. Axes of crenulations and small folds vary but are usually steep to vertical; slickensides generally plunge at low angles. The continuity and linearity of the Victoria Creek strike-slip fault zone, and its low-angle truncation of fold-and-thrust trends, demonstrate its steep dip and post-thrusting age. Except for possible dextral drag of some pre-existing thrusts, there is no direct evidence in the Livengood area alone for the sense and magnitude of slip on the Victoria Creek fault zone, but its character, its mappable continuity with both the Tintina and Kaltag faults, and its alinement between them, mark the victoria Creek fault as a fundamental link in a Tintinavictoria Creek-Kaltag right-lateral strike-slip fault system.

The Tozitna fault zone, located along the north edge of the Livengood area, is not exposed in the Livengood area, but its physiographic expression and curvilinear trace indicate that it is a splay of the Tintina system. About $55 \mathrm{~km}$ of right-separation is estimated for the Tozitna fault from the offset of the basal contact of the Tozitna stratigraphic belt from point $D$ to $D^{\prime}$ on figure 8 . The basal Tozitna contact also appears to be offset right-laterally $10 \mathrm{~km}$ or less between the East and West Crazy Mountains (locality E, figure 8), and between the East Crazy Mountains and the western Charley River area, possibly indicating two additional but minor splays of the Tintina fault system.

In contrast with the strike-slip zones, thrust contacts are relatively narrow and sharply defined, typically are stratigraphically controlled, are associated with large-scale low-plunging folds, are not expressed by a topographic trench, and form systems of splaying individual thrusts, each of relatively limited extent and displacement. Most thrust faults are also poorly exposed, but they can be clearly identified in most places by stratigraphic truncations and older-onyounger stratigraphic repetition. 
In most of the Livengood area south of the Victoria Creek fault, older-onyounger thrust relations, the mapped traces of thrust faults, rare overturned folds, and geophysical modeling (Cady and Morin, in press; Long and Miyaoka, in press) all indicate that the major northeast-trending thrusts dip to the southeast and had transport directions toward the northwest (fig. 8). Based on preliminary resistivity cross-sections by Long and Miyaoka (in press), the White Mountains stratigraphic belt was thrust about $10 \mathrm{~km}$ across the Beaver Creek belt along the largest of these thrusts, here named the Beaver Creek thrust (fig. 8). Numerous northwest-directed older-on-younger thrusts also imbricate the Wickersham, white Mountains, and Livengood stratigraphic belts. Preliminary interpretation of geologic sections (Dover, 1988, Pl. II-B) suggests most of these thrusts have small displacements of a few kilometers or less.

Near the west edge of the Livengood quadrangle, thrust trends wrap nearly 180 degrees around a major west-plunging anticline or anticlinal duplex, so that north- to northeast-trending thrusts in the western part of the Livengood area dip northwest and have southeast-directed movement (fig. 8). This "bend" is analogous in character to that of the Charley River area. All major thrusts in the Schwatka, Crazy Mountains, and Tozitna stratigraphic belts north of the TintinaVictoria Creek-Kaltag fault, also have southeastward-directed transport, including some with younger-on-older displacements that are interpreted as detached and thrusted stratigraphic contacts.

Structural timing--Dateable thrusting in the Livengood area involves rocks of the Wilber Creek unit as young as Early Cretaceous, and pre-dates strike-slip movement on the Victoria Creek and Tozitna faults. At one locality (labeled $F$ on figure 8 ), dolomite tentatively assigned to the Amy Creek unit is interpreted by Weber and others (1988) as having been thrust over the Victoria Creek fault, but this seems unlikely because the topographic trench representing the Victoria Creek zone appears to persist unbroken across and therefore post-date the alleged thrust. Pre-Cretaceous thrusting is possible but cannot be demonstrated.

Local evidence for the time of the principal strike-slip movement on the Tintina fault and its major splays in the Livengood area is that it cuts obliquely across and therefore post-dates fold and thrust trends involving Wilber Creek rocks as young as Early Cretaceous, and its principal movement pre-dates the deposition of poorly dated Tertiary(?) rocks. The idea that an earlier phase of major strike-slip and accompanying graben formation along an ancestral Tintina system controlled Jurassic to Lower Cretaceous (and possibly older) Wilber Creek deposition in the Beaver Creek stratigraphic belt (Weber (written communs., 1987) is incompatible with the regional distribution of lithologically equivalent rocks. All the rocks of the Beaver Creek belt appear to have lateral equivalents within regionally developed thrust-telescoped sequences of the Charley River and Dawson areas that are cut by the Tintina fault and extend far beyond the limits of the fault zone. The Wilber Creek unit, in particular, is correlated by Weber and others (1988, p. 36) with the Kathul Graywacke of the Kandik Group in the Charley River area. This unit represents a foreland basin sequence traceable into the foothills of the Brooks Range (Young, 1973), rather than a locally developed strike-slip graben deposit. Tertiary reactivation of the Tintina zone is indicated by numerous faults whose dip-slip components of movement are obvious, but which may have lateral-slip components as well. As much as $50 \mathrm{~km}$ of late 
Tertiary or Quaternary right-slip is postulated by Barker (1986) on the basis of geomorphic evidence. Modern fault scarps south of the Crazy Mountains (Foster and others, 1983) indicate that the Tintina fault zone is still active.

Although Tintina fault movement was of a magnitude and scale capable of affecting pre-existing structures in adjacent wallrocks, such effects in the eastcentral Alaska region appear to have been relatively minor readjustments, such as the drag of pre-Tintina thrust faults recognized in the Charley River area, or possibly the tightening up of compressional structures--a process that would require closer control on the timing of thrust movements to demonstrate than is currently available. In this region at least, the interpretation most in accord with observed geologic relations is that Cordilleran fold-and-thrust belt development and Tintina strike-slip are unrelated events separated in time.

The Livengood area as a segment of the Charley River fold-and-thrust belt displaced by the Victoria Creek-Kaltag and Tozitna splays of the Tintina fault system. Right-lateral displacement on the east-central Alaskan segment of the main Tintina fault system was estimated by Chapman and others (1985) to be 160 to $180 \mathrm{~km}$, , based on: (1) estimates of displacement along the Kaltag fault farther west, assuming a Kaltag-Tintina connection, and (2) estimated offset between the Lower Cretaceous Kandik Group in the Charley River area and presumably correlative flyschoid rocks at the east end of the Beaver Creek stratigraphic belt in the Livengood area. This estimate differs considerably from the $450 \mathrm{~km}$ of rightseparation documented for the Tintina system in central Yukon Territory by Tempelman-Kluit (1979) and Gordey (1981). One possible explanation for this discrepancy is transpression, whereby the $270 \mathrm{~km}$ of excess Canadian strike-slip motion was absorbed in the Livengood area by compressive thrusting on splays that bend or horsetail southwestward from the main Tintina fault zone at the leading edge of the northwestward driving upland. However, the geology of the Livengood and adjacent areas does not support a transpressive model because:

(1) The assumptions on which previous estimates of Tintina movement in eastcentral Alaska are based are invalid. Although a Kaltag-Tintina connection has been tracked through the Livengood area via the Victoria Creek fault by current mapping, other major faults with possibly large lateral components of movement by which Tintina strike-slip could have been distributed and dissipated (Dover, 1985b) have now been recognized in southwest Alaska (Patton and Moll, 1982). Thus the discrepancy in amount of movement that the transpressive model was invoked to explain is in doubt.

(2) As presently mapped, the polymictic conglomerate-bearing wilber Creek unit does not reach the easternmost end of the Beaver Creek stratigraphic belt, which has generally been restored against the Kandik basin sequence of the Charley River area in Tintina reconstructions used in support of the $180 \mathrm{~km}$ estimate of separation (Chapman and others, 1985). Even if it did, the conglomeratic rocks of the Beaver Creek belt do not match well with the Biederman Argillite and Keenan Quartzite, which are the units of the lower Kandik Group exposed on the north side of the Tintina zone in the Charley River area. However, a section of folded and thrusted argillite and thick Keenan-like quartzite remarkably similar to that in the Kandik Group does characterize the western part of the wilber Creek belt in the westernmost Livengood quadrangle, and the displacement required to juxtapose 
these western Livengood units with their lithologic counterparts in the Charley River area is about $400 \mathrm{~km}$.

(3) Thrust faulting in the Livengood area appears to be comparable in style and magnitude, and involves some similar stratigraphic sequences as that in the Charley River fold-and-thrust belt, which predates and is clearly cut by the Tintina fault system. Even if all the thrusts were transpressional, the amount of shortening they could accomodate would be at most only a small fraction of the alleged $270 \mathrm{~km}$ discrepancy between previous estimates of Tintina fault displacement in central Yukon Territory and east-central Alaska. Nor is crustal thickening by brittle thrusting or ductile processes in the Yukon-Tanana upland (Foster and others, 1987, and this volume) known to be of appropriate Late Cretaceous to early Tertiary age and of sufficient magnitude to account for such drastic crustal shortening during Tintina time.

The main alternative to transpression is that Tintina fault displacement in east-central Alaska was comparable to that in Yukon Territory (Dover, 1985b). The concept of comparable displacement is supported by the remarkable similarity between the stratigraphic belts of the Livengood area and those of the Dawson area of west-central Yukon Territory, areas now separated by nearly $400 \mathrm{~km}$, whose possible connection was recognized by Tempelman-Kluit (1971, 1984). In the southeast Dawson quadrangle, northeast-trending, northwestward-moving, thrustbounded rock sequences described by Green (1972) and Thompson and Roots (1982) are truncated at a high angle by the Tintina fault zone (fig. 10). These sequences, from structurally highest (on the southeast) to lowest (on the northwest), and their suggested Livengood area equivalents, are:

(a) A belt of internally deformed and weakly metamorphosed Late Proterozoic to Lower Cambrian grit, maroon and green slate, and minor black limestone, overlain by gabbro-bearing Ordovician and Silurian Road River Formation. Corresponding rocks of the Livengood area are the Wickersham grit unit and the Fossil Creek Volcanics in the Wickersham and White Mountains stratigraphic belts.

(b) Strongly folded and imbricately thrusted Keno Hill quartzite of late Paleozoic age and associated gabbro (R. I. Thompson, written communication, 1986). Corresponding rocks of the Livengood area are the undated but petrologically similar Globe quartzite and gabbro unit in the White Mountains stratigraphic belt.

(c) Carbonaceous phyllitic argillite, slate, and quartzite of a "lower schist" unit to which a Jurassic age was assigned by Green (1972), but which in the area remapped by Thompson and Roots (1982) contains at least some chertpebble-rich polymictic conglomerate resembling that in the Lower Mississippian and Devonian Earn Group. Corresponding rocks of the Livengood area are the Vrain unit in the Beaver Creek stratigraphic belt. Also, a discontinuous band of Triassic limestone and limy shale underlying the "lower schist unit" of the Dawson corresponds to locally occurring but undated calcareous rocks tentatively assigned to the lower part of the Glenn Shale (Triassic) in the Beaver Creek belt.

(d) Chert-rich and tuffaceous? rocks in a second belt of the Ordovician and Silurian Road River Formation, which here is locally deposited on mafic sills. 


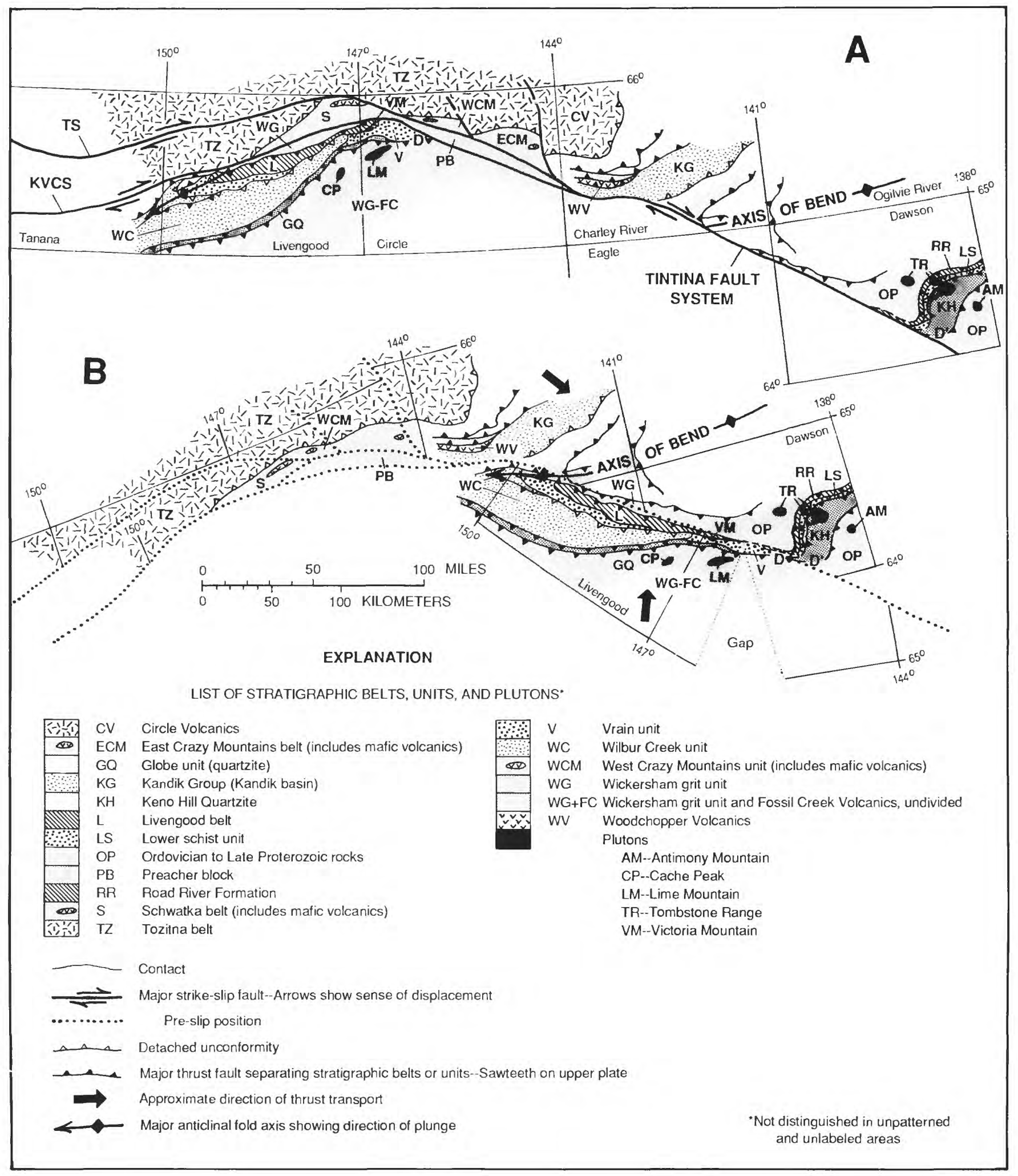

Figure 10. Tintina fault separation. Points $D$ and $D^{\prime}$ are two originally adjacent reference points displaced by Tintina fault movement. A, Present configuration. B, Restored pre-Tintina configuration. 
The corresponding unit of the Livengood area is the Livengood Dome Chert in the Livengood stratigraphic belt.

(e) A heterogeneous, Late Proterozoic to Lower Cambrian unit of chert, clastic rocks, minor limestone, and abundant mafic intrusive and extrusive material marking local volcanic centers. Corresponding rocks of the Livengood area comprise the heterogeneous unit in the Livengood stratigraphic belt; and

(f) Late Proterozoic maroon and green slate, grit, and minor limestone, similar to that in (a). Corresponding rocks of the Livengood area comprise the wickersham grit unit which underlies the heterogeneous unit in the Livengood stratigraphic belt.

Predictably for a fold-and-thrust belt involving abrupt facies transitions, there are some important lithologic variations among the structural plates correlated between the Livengood and Dawson area, especially in the relative abundances of lithic components. Furthermore, the Amy Creek unit of the Livengood stratigraphic belt (e) has no presently known counterpart in its corresponding sequence of the Dawson area. However, similar carbonates are common in the underlying structural plate at Dawson, below the Dawson thrust (Thompson and Roots, 1982). Considering the variability of stratigraphic details within the thrust belt, the remarkably high degree of correspondence of distinctive lithologic units and associations within individual thrust-bounded sequences between the two areas, as well as similarities in structural style and vergence, and in the distribution of low-grade metamorphic effects, all provide strong evidence that the two areas were directly connected before Tintina strike-slip fault movement. I therefore interpret the eastern Livengood area to be a segment of the northern Cordilleran fold-and-thrust belt displaced by the Tintina fault zone from the Dawson and Charley River areas.

Restoring the easternmost Livengood area to an original position opposite the Dawson area has two important consequences for correlations between the Livengood and Charley River areas. First, the Wilbur Creek unit at the west end of the Beaver Creek stratigraphic belt, rather than that at the east end, is alined with the Kandik basin (figs. 8 and 10). This alignment produces a far more satisfactory connection between the lower units of the Kandik Group cut-off by the Tintina fault in the Charley River area, and the part of the wilber Creek unit containing a prominent Keenan-like quartzite unit. Second, the "bend" separating northwest- and southeast-directed thrusts in the Livengood area is alined with the axis along which thrust trends and transport directions change in the same way in the Charley River area (fig. 10).

\section{Ray Mountains area}

The Ray Mountains area, as defined here, includes the Ray Mountains proper, in the north half of the Tanana and southernmost part of the adjacent Bettles $1: 250,000$ quadrangles, and also the area between the Tozitna and Yukon Rivers in the south half of the Tanana quadrangle (fig. 3). The area spans the KokrinesHodzana upland (also known as the Ruby geanticline), from the Koyukuk basin on the northwest (Patton and others, in press) to the Yukon Flats basin. It is separated 
from the Livengood area on the southeast by the Kaltag-Victoria Creek splay of the Tintina fault system (figs. 1 and 2 ).

Previous work. A brief reconnaissance study by Eakin (1916) covers part of the area considered here, but attention was first focused on the Ray Mountains area in a report by Patton and Miller (1970) on the Kanuti ultramafic belt. Preliminary geologic maps at a scale of 1:250,000 of the Bettles (Patton and Miller, 1973), Melozitna (Patton and others, 1978), and Tanana (Chapman and others, 1982) quadrangles now cover the entire Ray Mountains area, and a few preliminary topical reports related to that mapping or earlier work are also available. The most applicable of these to the Ray Mountains area deal with the Kaltag fault (Patton and Hoare, 1968), the age of the Rampart Group (Brosge and others, 1969), and mapping at Sithylemenkat Lake (Herreid, 1969). The main impetus for more recent and on-going work in the Ray Mountains area was a multidisciplinary study along a transect across the Yukon-Koyukuk basin, from its southeast borderland in the Ray Mountains, to the south flank of the Brooks Range. of the many short topical reports and abstracts generated so far by the YukonKoyukuk transect, mostly published since 1985, those of Dover and Miyaoka $(1985 a, b, c)$ in the Ray Mountains area are emphasized in this review, and others are cited where relevant.

Geologic Framework. Dover and Miyaoka (1985a) separated the Ray Mountains segment of the Kokrines-Hodzana upland into three diverse and complex rock packages, and a fourth package is designated here. These are informally named the metamorphic suite of the Ray Mountains, in the central part of the range; the Kanuti assemblage, on the northwest; (3) the Rampart assemblage, on the southeast; and (4) the Devonian metaclastic sequence separating packages 1 and 3 (figs. 11 amd 12). The metamorphic suite of the Ray Mountains is part of the Ruby terrane of Silberling and Jones (1984), and the structurally flanking Kanuti and Rampart assemblages correspond to their Angayucham and Tozitna terranes, respectively. The mid-Cretaceous Ray Mountains granitic batholith was intruded mainly into the metamorphic suite, but it locally cuts all of the other assemblages. The map distribution of these major units is shown on figure 12 .

Metamorphic suite of the Ray Mountains--Five informal units comprise the Ray Mountains metamorphic suite. The structurally lowest two (units 1 and 2) may be autochthonous; the other three (units 3 to 5) are more structurally complex and are probably parautochthonous or possibly allochthonous.

Unit 1 is feldspathic quartzite containing 70 to 85 percent quartz, 10 to 20 percent intermediate plagioclase, and 2 to 10 percent mica. Most samples also contain a few percent of untwinned $\mathrm{K}$-feldspar, and many have as much as 5 percent garnet and(or) cordierite. The protolith was a slightly argillaceous, feldspathic, quartz-rich sediment of continental derivation but uncertain age.

Unit 2 is a mineralogically and texturally distinctive augen orthogneiss containing augen of igneous plagioclase, granulated quartz and plagioclase, or poikilitic simply twinned K-feldspar, in a cataclastic matrix of quartz, feldspar, and synkinematic micas. The augen orthogneiss has a Devonian U-Pb zircon age of $390 \pm 12 \mathrm{Ma}$ (Patton and others, 1987). Similar augen orthogneiss yields Middle Devonian to Early Mississippian $\mathrm{Rb}-\mathrm{Sr}$ whole-rock and $\mathrm{U}-\mathrm{Pb}$ zircon ages elsewhere in 


\section{EXPLANATION}

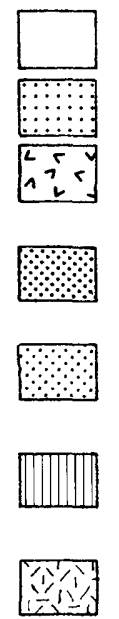

Q

Quaternary deposits, undivided

$T \quad$ Tertiary sedimentary rocks, undivided

TKv Felsic volcanic rocks (lower Tertiary to Upper Cretaceous)

Kqc Quartz-pebble conglomerate (Upper Cretaceous)

Kic Igneous-pebble conglomerate (Upper? and Lower Cretaceous)

$\mathrm{Kg}$ Graywacke and mudstone (Lower Cretaceous)

Granitic intrusive rocks (Cretaceous)-Includes Ray Mountains pluton

\section{Kanuti Assemblage}

Ju Utramafic unit (Jurassic and(or) older)

JMbc Chert and basalt unit (Jurassic? to Mississippian)

\section{Rampart Assemblage}

道: $\mathrm{Jm}$ Mafic igneous rocks (Triassic and older?)

KMr Rampart Group (Triassic? to Mississippian)--Sedimentary rocks

Devonian Metaclastic Sequence

DI Limestone and dolomite (Upper Devonian)

\% Dmw Blastomylonitic bimodal quartz-wacke and associated clastic rocks (Devonian and older?)
Metamorphic Suite of the Ray Mountains

Pzm Unit 5--Quartzite and marble (middle Paleozoic and older?)

MzPzm Unit 4--Metabasite (Mesozoic, middle Paleozoic or older?)

Pzs Unit 3--Pelitic to quartzitic schist (middle Paleozoic and older?)

MDao Unit 2--Augen orthogneiss (Devonian)

$€ Z$ Unit 1--Quartzofeldspathic paragneiss (lower Paleozoic or Late Proterozoic)

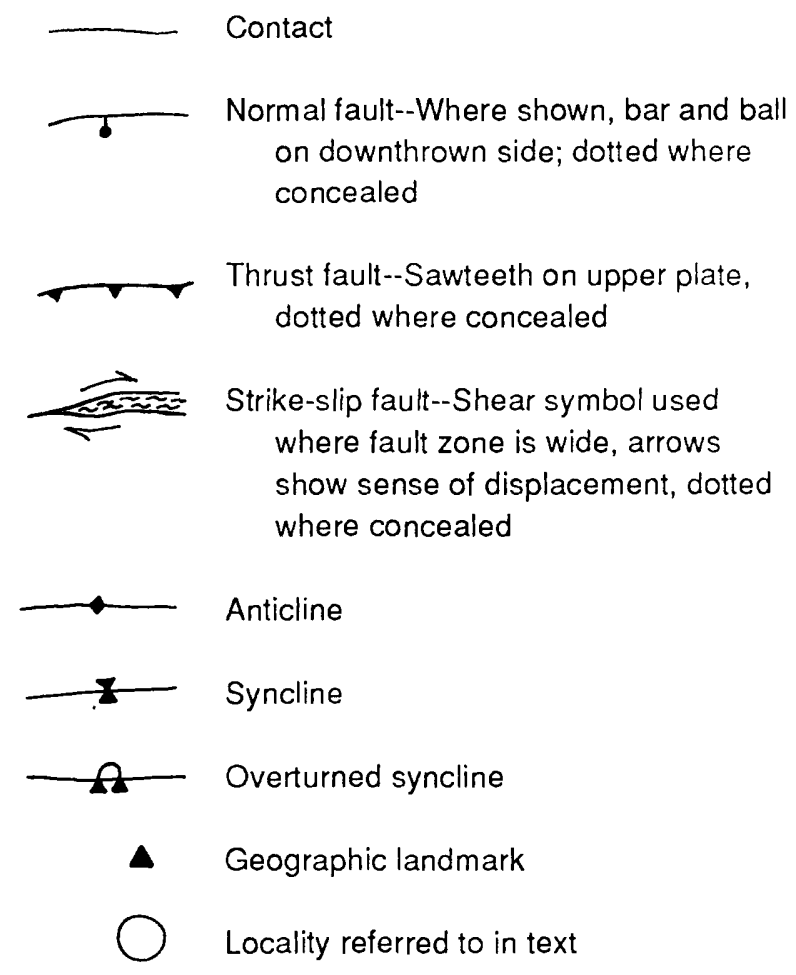

Figure 11.--Geologic map of the Ray Mountains area. See figure 3 for area location 


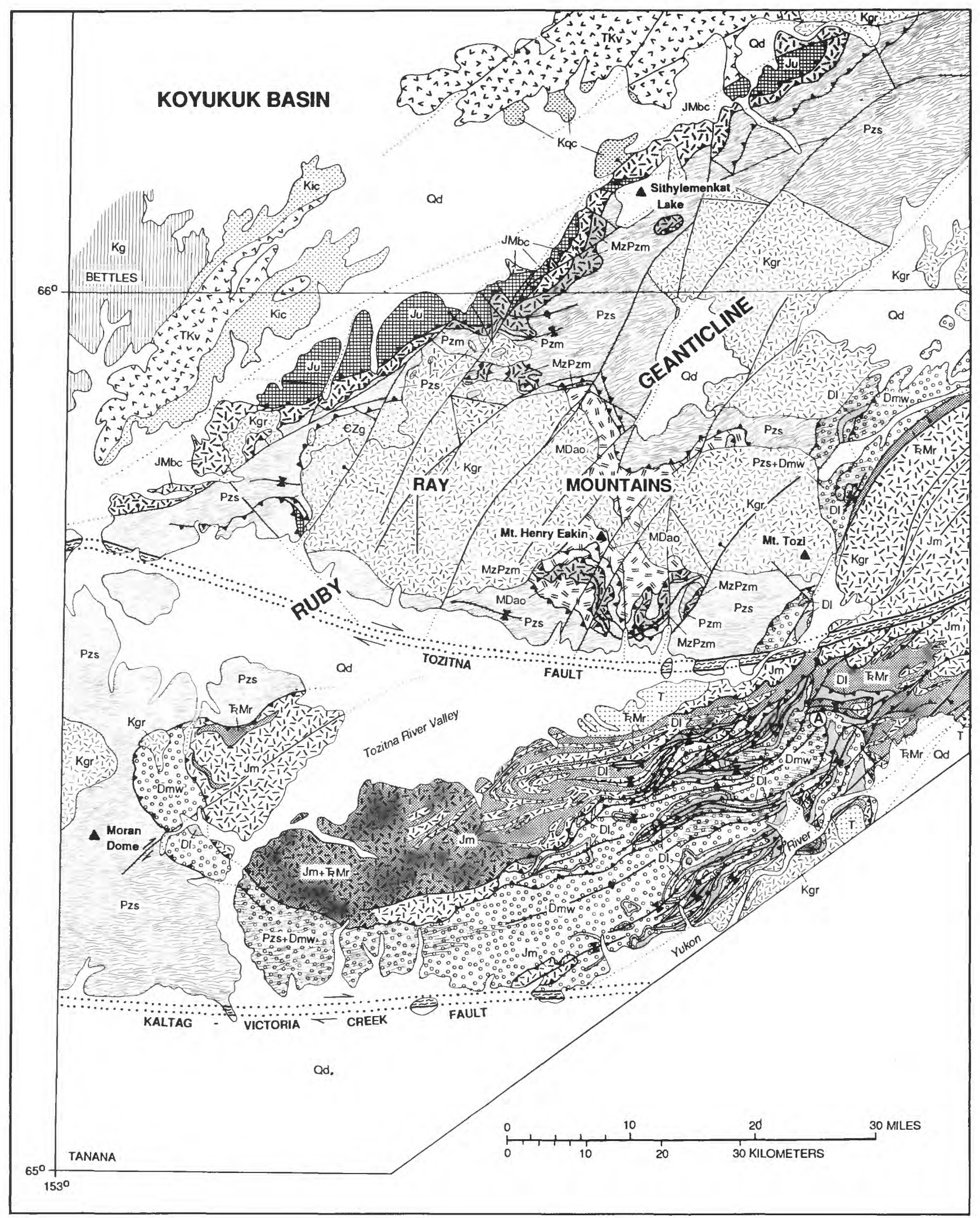




\begin{tabular}{|c|c|c|c|c|}
\hline$A G E$ & \multicolumn{4}{|c|}{ DESCRIPTION } \\
\hline & \multirow{7}{*}{\multicolumn{2}{|c|}{ 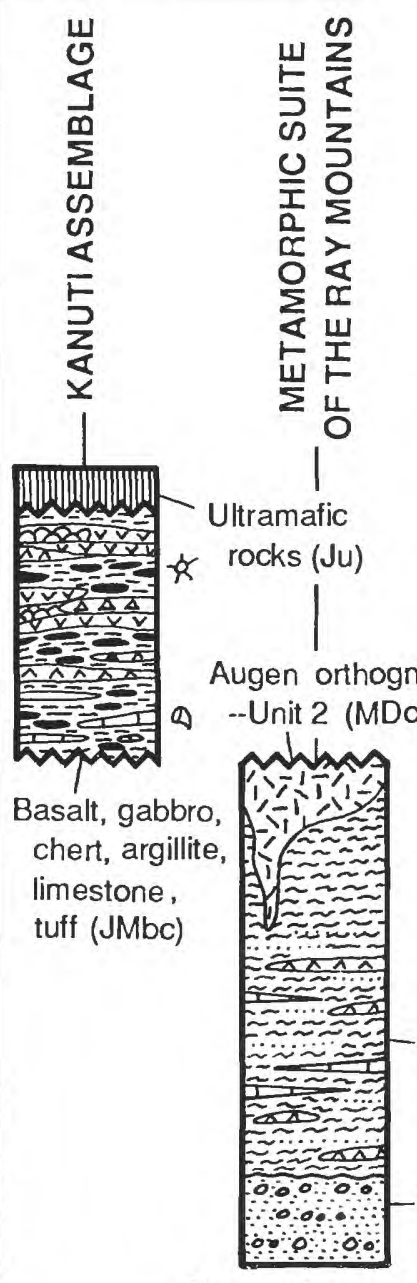 }} & 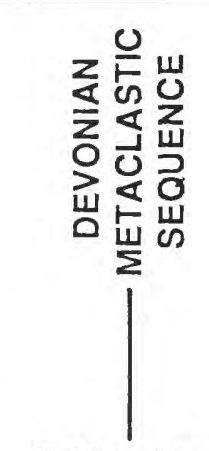 & 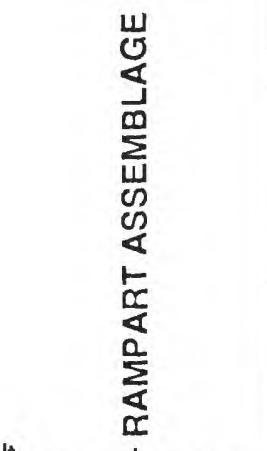 \\
\hline J & & & \multirow{3}{*}{\multicolumn{2}{|c|}{$\begin{array}{l}\text { Gabbro, basalt, } \\
\text { chert, argillite, } \\
\text { limestone } \\
\text { (Jm, KMr) } \\
\text { neiss } \\
\text { o) }\end{array}$}} \\
\hline 下 & & & & \\
\hline$\frac{N}{2}$ & & & & \\
\hline D & & & \multicolumn{2}{|c|}{$\begin{array}{l}\text { quartz-wacke, } \\
\text { phyllite (DI, Dmw) }\end{array}$} \\
\hline $\begin{array}{l}\text { N } \\
\text { o } \\
\text { J }\end{array}$ & & & \multicolumn{2}{|c|}{$\begin{array}{l}\text { Schist with quartz segregations, } \\
\text { phyllite, marble, metabasite } \\
-- \text { Units 3-5 (Pzs, MzPzm, Pzm) }\end{array}$} \\
\hline$€ z$ & & & \multicolumn{2}{|c|}{$\begin{array}{l}\text {-Quartzofeldspathic paragneiss } \\
\text {-- Unit } 1 \text { (€Zgn) }\end{array}$} \\
\hline & \multicolumn{4}{|c|}{ Base not exposed } \\
\hline
\end{tabular}

Figure 12. Generalized stratigraphic columns of the Ray Mountains area. See figure 5 for explanation of lithologic symbols, and figure 11 for explanation of map units. 
the metamorphic borderlands of the Yukon-Koyukuk basin (Dillon and others, 1979, 1980, and 1985). The protolith of the augen orthogneiss was granitic igneous rock that was probably intruded into the other four units.

Unit 3 is the most widely distributed and variable of the metamorphic units and consists mainly of pelitic to quartzitic schist. Subordinate interlayers are micaceous quartzofeldspathic schist, calc-schist or calc-silicate gneiss, amphibolitic schist, quartzite, marble, phyllonite, and, at one locality, metaconglomerate containing metabasite clasts as large as cobble size. Quartzsegregation layering and blastomylonitic fabric are characteristic, and bedding is transposed along the main foliation, which parallels axial surfaces of isoclinal folds. The schist varies widely in mineralogy and texture because of the complex interaction of polyphase deformation and polymetamorphic recrystallization superimposed on its diverse lithologic components. The protolith of most of the schist was siliceous argillite and argillaceous feldspathic to calcareous quartzrich sediment, which possibly originated as a turbidite having primary alternations of quartzofeldspathic and argillaceous layers.

Unit 4 consists of metamorphosed mafic igneous rocks, or metabasite, that occurs as large mappable bodies ranging from metagabbro and metadiabase to amphibolite and garnet-amphibolite. It also occurs as thin interlayers of amphibolitic schist and greenschist within unit 3 . The mappable mafic rock bodies grade in fabric and degree of recrystallization from weakly sheared and incompletely recrystallized in their cores to strongly sheared and extensively recrystallized along their margins.

Unit 5 is composed of relatively pure quartzite and marble. Beds thick enough to map separately on figure 11 are associated with metabasite bodies in the southern part of the Ray Mountains. A few thin interbeds of quartzite and marble also occur in unit 3.

Contacts between units within the metamorphic suite of the Ray Mountains are generally shallow-dipping, somewhat discordant blastomylonite zones in which ductile shear occurred under low-grade metamorphic conditions.

Preliminary analysis suggests that the mesoscopic fabric of the metamorphic suite of the Ray Mountains involves at least three deformational phases and three metamorphic episodes (Dover and Miyaoka, 1985b). The earliest folds (Fl, fig. 13) are isoclines to which the main schistosity (SI) is axial planar. Fl axes commonly parallel the axes of mapped folds. In thin section, Fl isoclines are associated with synkinematic amphibolite-facies minerals (MI). Fl isoclines are overprinted by second generation folds (F2) of variable style that have axial plane cleavage (S2) at a low to moderate angle with SI (fig. 13). Most F2 folds are small chevron folds with tight or even isoclinal forms. Tight F2 folds increase in abundance toward cataclastic zones between major rock units and assemblages, where the cataclastic foliation is the dominant fabric element and appears to coincide with S2. These second-generation structures throughout the metamorphic suite of the Ray Mountains are invariably associated with greenschistor locally glaucophanitic greenschist-facies mineral assemblages (M2). In rocks not strongly affected by the cataclastic event, M2 produced relatively minor retrogression of $\mathrm{Ml}$ minerals. In more strongly cataclastic rocks, many of 


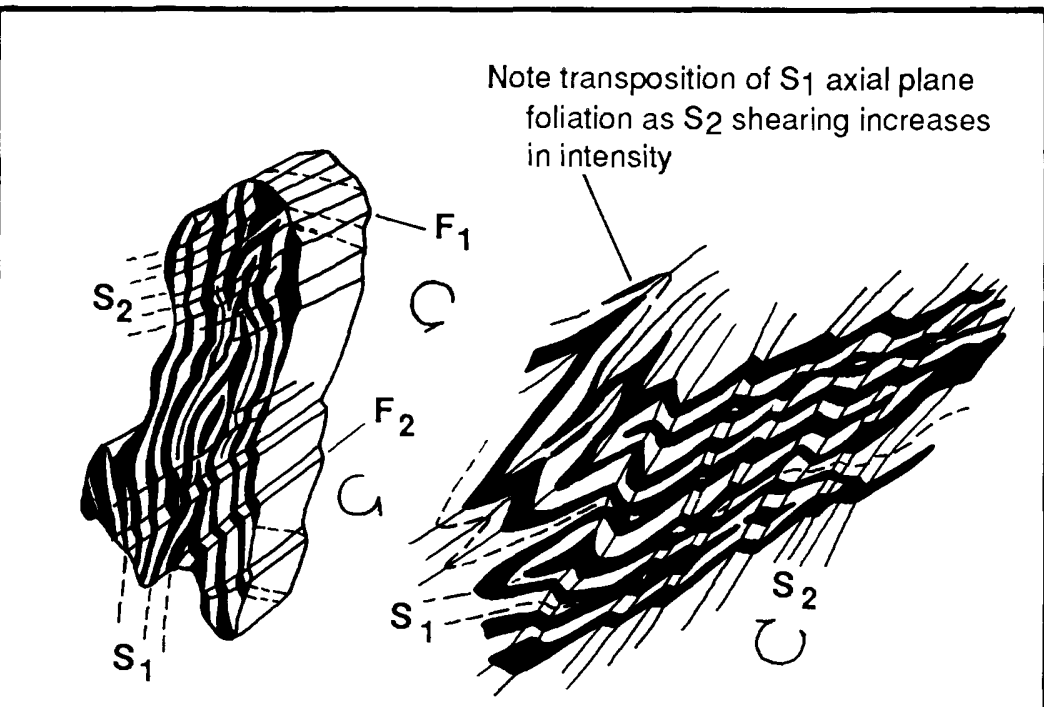

Variable mesoscopic scale

Figure 13. Sketches of superimposed mesoscopic structures. F, fold axis; S, axial plane foliation; subscripts indicate sequence of formation; arrows showing sense of rotation indicate asymmetry of folding.

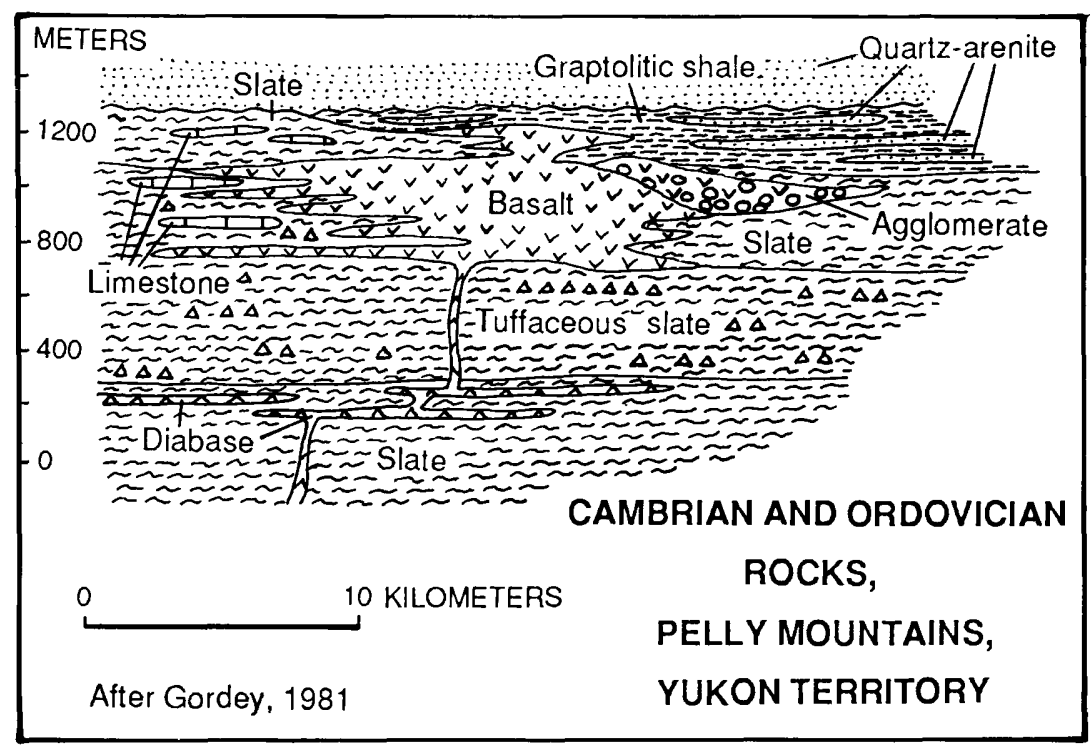

Figure 14. Possible protolith model for the metamorphic suite of the Ray Mountains. 
phyllitic aspect, Ml minerals are locally preserved as granulated or pseudomorphic relics cut by cataclastic S2 foliation with synkinematic M2 mineral assemblages. Such rocks are retrogressive phyllonites. All the graphitic chlorite-muscovitequartz schist of the Ray Mountains metamorphic suite is probably blastomylonite produced or affected by the M2 cataclastic event, and some of these rocks are demonstrably phyllonitic. In parts of the Ray Mountains not strongly affected by the cataclastic event, broad warps (F3) bend earlier structures in individual outcrops; F1 and F3 are coaxial in places. In strongly cataclasized zones, F3 folds are generally small crenulations that fold synkinematic M2 minerals and have only incipiently recrystallized axial-plane cleavage (S3) that cuts the cataclastic 52 foliation. Hornblende-hornfels facies mineral assemblages (M3) occur in a contact metamorphic aureole several kilometers or less wide around the mid-Cretaceous Ray Mountains granitic batholith. M3 is generally post-kinematic relative to F2/S2 and earlier structures, and may represent a late, post-kinematic phase of $\mathrm{M}_{2}$. However, in the easternmost part of the Ray Mountains metamorphic suite, where it is in contact with the Devonian metaclastic unit and the Rampart assemblage, M3 garnet and albitic plagioclase porphyroblasts are rotated within a cataclastic foliation that is probably $\$ 3$ but could possibly be $\$ 2$.

Kanuti assemblage--Two tectonically juxtaposed units form the Kanuti assemblage, which lies on the northwest side of the metamorphic suite of the Ray Mountains. A lower chert-basalt unit contains discontinuous and largely unsheared blocks and lenses of incipiently recrystallized basalt, diabase, gabbro, and serpentinized ultramafic rocks in a mylonitic, melange-like matrix of low-grade metasedimentary rocks that include bedded chert of Triassic age, argillite, slate, Mississippian limestone, and volcaniclastic rocks (W. W. Patton, written commun., 1983). The structurally overriding ultramafic unit contains cryptically deformed, extensively serpentinized layered gabbro, peridotite, harzburgite, and dunite, with garnet-amphibolite possibly derived from eclogite at the base. $\mathrm{K}$-Ar ages on hornblende from the garnet amphibolite are 138, 149, and $161 \mathrm{Ma}$ (W. W. Patton, written commun., 1983). Primary igneous and sedimentary textures and mineralogy are typically preserved in the Kanuti assemblage, which was interpreted to be dismembered ophiolite by Patton and others (1977) and Loney and Himmelberg $(1985 a, b)$.

Although contacts between the Kanuti assemblage and the metamorphic suite of the Ray Mountains are poorly exposed, the Kanuti appears to lie in low- to moderate-angle thrust contact on the metamorphic suite because of the intensity of shearing in the lower, chert-basalt unit, and the regional discordance of its basal contact with deformed units of the underlying metamorphic suite. The Kanuti ophiolite is interpreted to be a slice of the oceanic basement of the koyukuk basin that was obducted southeastward onto the continentally derived metamorphic suite of the Ray Mountains (Patton and Box, 1985; Cady, 1986; Miller, 1985; Arth, 1985; Patton and others, in press, b). If so, obduction appears to have been completed by mid-Cretaceous time, because emplacement of the Ray Mountains batholith locally produced contact metamorphic effects in the Kanuti ophiolite (W. W. Patton, written commun., 1983). Also, at one locality in the chert-basalt unit, bedded chert displays three phases of folding similar in style, orientation, and mutual angular relationships to folds in the adjacent metamorphic suite (Dover and Miyaoka, 1985b). This similarity suggests that the Kanuti assemblage was in place or was close enough to the borderland in pre-mid-Cretaceous time to have 
participated in the same folding history as the metamorphic suite. The amount of obduction represented by the Kanuti belt is controversial and relates to the problem of the origin of the Tozitna terrane (Rampart assemblage) discussed on pages MS p. 76-80, but obduction may not have extended much beyond the present limits of Kanuti exposures.

Rampart assemblage--The term Rampart assemblage, as used informally here, includes the Rampart Group of Mertie (1937), as well as voluminous associated mafic intrusive rocks. So defined, the Rampart assemblage corresponds to the Tozitna stratigraphic belt of the Livengood area. The Rampart Group contains basalt, pillow basalt, phyllite, argillite, slate, arkosic semischist, volcaniclastic rocks, conglomerate, Permian limestone, and radiolarian chert of Mississippian to Triassic(?) ages (Jones and others, 1984). Intrusive rocks included in the Rampart assemblage are mainly diabase and gabbro, but subordinate diorite and minor serpentinized ultramafic rocks occur as well. A $\mathrm{K}-\mathrm{Ar}$ age of $210 \pm 6 \mathrm{Ma}$ (Triassic) is reported by Brosgè and others (1969) on hornblende from gabbro near the town of Rampart.

Devonian metaclastic sequence--Also tentatively included in the Rampart assemblage by Dover and Miyaoka (1985a) were low-grade cataclastic rocks that lie structurally between the Rampart Group and the metamorphic suite of the Ray Mountains in the southeastern Ray Mountains. Blastomylonitic quartz-wacke with bimodal quartz grain-size distribution is the dominant and most distinctive lithology, but associated rocks include contorted phyllite, platy arenaceous limestone, slightly argillaceous quartz-siltstone, poorly sorted limonite-spotted quartzite with limy cement, and pebbly mudstone with clasts as much as $2 \mathrm{~cm}$ in diameter of limestone, quartz, quartzite, chert, argillite, and feldspathic quartz-arenite. No local evidence was found in the southeastern Ray Mountains for the protolithic age of the bimodal quartz-wacke unit, but the Devonian(?) age (Dover and Miyaoka, 1985a) suggested by analogy with lithologically similar rocks of the Beaver quadrangle to the north (Brosgè and others, 1973) is now confirmed by the recovery of latest Devonian (Famennian) conodonts (Anita Harris, written communs., 1985 and 1986) from platy limestone ("limestone and dolomite unit" of Figure 11) associated with the bimodal unit in the area between the Tozitna and Yukon Rivers.

New lithologic, textural, and paleontological data on these cataclastic to blastomylonitic rocks in the Tozitna-Yukon Rivers area makes their designation as a separate Devonian metaclastic sequence lying between the Rampart assemblage and the metamorphic suite of the Ray Mountains more appropriate than assignment to the Rampart. The Devonian metaclastic sequence contains some rock types similar to those in the Rampart assemblage, but it differs in the predominance of quartzrich, commonly bimodal clastic rocks, and in being slightly older than the oldest rocks documented in the Rampart assemblage. It contains some mafic intrusive material, but less than occurs in the Rampart assemblage.

The grade and intensity of metamorphic recrystallization of the metaclastic sequence appear to increase gradually westward (down section) from unequivocal Rampart rocks, toward the metamorphic suite of the Ray Mountains, with which its metamorphic textures merge and become indistinguishable. However, clearly recognizable primary sedimentary textures and clasts are typically preserved in 
the metaclastic sequence, and in this respect it is less thoroughly tectonized and recrystallized in most places than is the Ray Mountains metamorphic suite. Metamorphic gradation was tentatively attributed to metamorphic convergence, caused by retrogressive phyllonitization in the metamorphic suite of the Ray Mountains, and progressive metamorphism in structurally detached rocks now assigned to the Devonian metaclastic sequence (Dover and Miyaoka, 1985b).

Fabric data from the Devonian metaclastic sequence in the southeastern Ray Mountains define broadly folded but generally southeast-dipping blastomylonitic foliation and include mineral lineations interpreted as indicators of northwestsoutheast movement. Two lines of evidence were cited by Miyaoka and Dover (1985) for up-dip movement from southeast to northwest toward the metamorphic core of the Ray Mountains: (1) Five of the six asymmetrical folds observed in the metaclastic sequence verge to the northwest, and a major east-west-trending fold in the underlying metamorphic suite appears to be overturned northwestward. (2) In a preliminary study of shear sense, the preponderance of shear data also suggest northwestward-directed up-dip shear; movement indicators include s-c tectonites, asymmetrical augen, porphyroblast tails, and microfolds. If mylonitization was related to movement of the overlying Rampart assemblage, the microfabrics indicate it moved northwestward toward the crest of the Ruby geanticline. Recent additional fabric data confirm a consistent northwest-directed sense of shear for the southeastern flank of the Ray Mountains, but show numerous variations in trend and inconsistencies in sense of shear for the Ray Mountains area as a whole (Miyaoka and Dover, in press).

Ray Mountains pluton--The Ray Mountains pluton is alined east-west across the northeast-trending Ruby-Hodzana upland. A reconnaissance map by Puchner (1984) shows the Ray Mountains batholith to be a composite of at least four separate intrusive phases ranging from $\mathrm{K}$-feldspar-rich porphyritic granite, biotite granite, and two-mica granite, to granodiorite. Several K-Ar, Rb-Sr whole rock, and U-Pb ages from various phases of the Ray Mountains batholith range from 104 to $111.6 \mathrm{Ma}$ (Puchner, 1984; Silberman and others, 1979a; Patton and others, 1987). The isotope chemistry of the Ray Mountains pluton and other granitic plutons of the Ruby geanticline indicates that they are s-type plutons derived from or contaminated by continental crust (Miller, this volume). Slight contact metamorphic effects are present in the Kanuti assemblage at the west end of the Ray Mountains pluton, and an intrusive contact between a granitic pluton of similar age and the Kanuti assemblage was mapped by Patton and others (1978) in the Melozitna quadrangle, just southwest of the Ray Mountains. These relations establish the mid-Cretaceous as a younger limit for the time of obduction of the Kanuti assemblage. At the east end of the Ray Mountains batholith (Mt. Tozi lobe), contact metamorphic (M3) garnet and albitic plagioclase porphyroblasts in the Devonian clastic sequence were rotated by mylonitization, indicating that at least the latest movement there postdates the mid-Cretaceous.

Brittle fracture and strike-slip faulting--Tozitna fault--A brittle fracture fabric and high-angle fault pattern are superimposed on the more ductile older fabrics of the Ray Mountains area (fig. 11). The brittle structures are expressed mainly by northeast-trending topographic lineaments having generally small downto-the-northwest dip-slip offsets. Geophysical modeling by Cady (1986) suggests that post-thrusting high-angle faults having similar northeast-trend and 
significant down-to-basin displacement cut the obducted northwest margin of the Ray Mountains just west of Kanuti ophiolite exposures.

The Tozitna fault (fig. 11) in the southeastern Ray Mountains area is a strike-slip fault zone about $1 \mathrm{~km}$ wide containing steep kink-fold axes and pervasive low-plunging slickensides (Dover, 1985b). Its curvilinear trace can be followed for more than $250 \mathrm{~km}$ by alined topographic valleys and low drainage divides or saddles across ridges from the margin of the Koyukuk basin, across the Tanana and Livengood quadrangles at the south edge of Yukon Flats basin, and into the Tintina fault system. It displaces the contact between the Rampart assemblage and the Devonian metaclastic sequence from its position in the southeastern Ray Mountains to that south of the Tozitna River about $55 \mathrm{~km}$ in a right-lateral sense, a separation comparable with that determined for the Tozitna fault in the Livengood area.

Implications of new mapping between Tozitna and Yukon Rivers. The best exposures of the contacts between the metamorphic suite of the Ray Mountains, the Devonian metaclastic sequence, and the Rampart assemblage are in the part of the Ray Mountains area lying between the Tozitna River and the Yukon River (fig. 11). But here, as in the Mt. Tozi area of the southeastern Ray Mountains, the distinctions between these sequences are obscure in places. Thick diabase sills and associated sedimentary rocks typical of the Rampart assemblage are underlain by a bimodal quartz-wacke-bearing unit that is similar in most of its associated lithologies and petrologic characteristics to the metaclastic sequence of the southeastern Ray Mountains. The main differences are that in the Tozitna-Yukon Rivers area, (1) the carbonates are mainly dolomite or dolomitized limestone, and (2) low-grade metamorphic recrystallization of the quartz-wacke unit is locally more advanced than in the southeastern Ray Mountains. At locality $A$ on figure 11, an argillaceous part of the blastomylonitic quartz-wacke unit grades into garnetmuscovite schist, and the post-kinematic static growth of contact metamorphic biotite, andalusite, and albite indicates a buried pluton nearby. Even so, primary sedimentary textures persist in most places within the bimodal quartzwacke, and a few conodonts of latest Devonian (Famennian) age (A.G. Harris, written commun., 1984) are preserved in thin platy arenaceous limestone beds associated with the dolomite.

Carbonate marker beds in the dominantly metaclastic sequence define large folds and thrusted folds. Folding and thrusting clearly involved rocks of the overlying Rampart assemblage. Locally, conodont-bearing Famennian limestone similar to but thicker than that typical of the metaclastic sequence appears to be infolded with only incipiently metamorphosed metachert, meta-argillite, and metadiabase tectonite at the base of the Rampart assemblage. Also, metachert that yields Mississippian to Triassic radiolarians (Jones and others, 1984), limestone containing poorly preserved middle to late Paleozoic corals (Chapman, 1974), and thick diabase sills, all belonging to the Rampart assemblage, are structurally imbricated with the metaclastic sequence in places. Thrusts dip north, and where folds are asymmetrical, vergence is to the south or southeast. However, shear indicators in tectonites of the Devonian metaclastic unit generally indicate a top-to-the-north, -northwest, or -west sense of shear, suggesting a complex history of movement for the contact between the Rampart sequence and the Devonian metaclastic unit (Miyaoka and Dover, in press). The imbricated contact has a 
broadly anticlinal northeast-plunging form in the eastern part of the TozitnaYukon Rivers area. The area of highest metamorphic grade and contact-metamorphic effects, near the bend in Canyon Creek (locality A, fig. 11), occurs along the anticlinal axis, suggesting that the buried pluton inferred there occurs in the core of the broad anticline.

Near Moran Dome (fig. 11), at the west end of the Tozitna-Yukon Rivers area, low- to medium-grade schist with quartz segregations resembling schist in the metamorphic suite of the Ray Mountains, is intruded by probable mid-Cretaceous granite. Medium-grade mineral assemblages are restricted to the contact aureole of the pluton. The dominantly low-grade rocks of the Moran Dome area are similar in composition, mineralogy, and texture to the most extensively recrystallized parts of the metaclastic sequence in the Canyon Creek area to the east. However, continuity between the two areas is masked by poor exposures and the intervening occurrence of less completely recrystallized rocks of the metaclastic sequence and diabase of the Rampart assemblage. About $8 \mathrm{~km}$ northeast of Moran Dome, differences in metamorphic grade and degree of recrystallization between the Ray Mountains metamorphic suite and the Devonian metaclastic unit appear to be telescoped by east-dipping thrusts. Sense of shear determined from s-c tectonites in this area is variable, and blastomylonitic lineations participated in broad post-shear folding. However, the best-developed s-c fabrics indicate top-towardthe-west and -northwest up-dip movement (Miyaoka and Dover, in press; Smith and Puchner, 1985), as they do in the southeastern Ray Mountains.

From relations mapped in the Tozitna-Yukon Rivers area, the contact between the Rampart assemblage and the Devonian metaclastic sequence is interpreted as a zone of ductile detachment, complicated by later folding and imbricate thrusting, separating two vertically stacked sequences that may originally have been in stratigraphic continuity. Detachment was probably controlled by fundamental differences in ductility between the two sequences--a more competent, mafic-rich, typically Rampart upper sequence that is latest Devonian and younger in age, and a less competent, quartz-wacke-rich lower sequence that is latest Devonian and older in age. Variable and locally divergent sense-of-movement data indicate a complex history of movement for this contact. The contact between the Devonian metaclastic sequence and the metamorphic suite of the Ray Mountains is also strongly sheared, and is further obscured by metamorphism that increases gradually in grade and degree of recrystallization with depth and toward granitic plutons. An original stratigraphic contact, possibly an unconformity, is possible, but cannot be proved. It is also possible that all of the multiphase deformation and polymetamorphism of the metamorphic suite of the Ray Mountains occurred in one prolonged and intermittently active orogenic event, the ductile and brittle effects of which were largely depth-controlled and overlapping in time. Early ductile fabrics formed moderately deep in the crust may have been overprinted by more brittle fabrics later in the orogenic cycle, as structural thickening of the crust drove uplift of the Ruby terrane.

Protoliths of metamorphic rocks in the Ray Mountains area. The protolith of the main body of the metamorphic suite of the Ray Mountains was quartz-rich, dominantly argillaceous, possibly turbiditic sediment, containing subordinate mafic-igneous intercalations and a few interbeds of quartzite, calcareous sediments, volcaniclastic rocks, and limestone (units 3-5, figs. 11 and 12); 
possible basement rocks are coarse-grained to gritty quartzitic to quartzofeldspathic rocks (unit 1, figs. 11 and 12). The heterogeneous protolith of the Devonian metaclastic sequence (figs. 11 and 12) includes bimodal quartzwacke, siliceous argillite and chert, iron-rich and locally carbonate-cemented quartzite, polymictic conglomerate, mafic sills and dikes, and latest Devonian (Famennian) limestone. In lithologic character, these rock types resemble those in lower to middle Paleozoic assemblages deposited on gritty Wickersham (Late Proterozoic) basement in the Livengood area, and in the outer part of the Cordilleran miogeocline in general. Appropriate protolithic models are the stratigraphic reconstructions described by Gordey (1981) for the Selwyn basin and Cassiar platform of south-central Yukon Territory (fig. 14), which contain all of the lithic elements represented in the metamorphic suite of the Ray Mountains and the Devonian metaclastic unit.

\section{Beaver area}

As defined here, the Beaver area includes parts of the Beaver, Chandalar, Christian, and Arctic $1: 250,000$ quadrangles, and extends from the northeastern part of the Kokrines-Hodzana upland into the southeastern Brooks Range (fig. 3 ).

Previous work. Parts of the Beaver area were included in the pioneering reconnaissance studies of Schrader (1900, 1904), Maddren (1913), and Mertie (1925, 1929). The most recent geologic maps of the Christian, Chandalar, and Arctic quadrangles were completed by Brosgè and Reiser in 1962, 1964, and 1965, respectively; the Beaver quadrangle was mapped by Brosge and others (1973). Topical studies, some of regional scope, include Brosge (1960, 1975), Brosgè and others (1962), Reiser and others (1965), Chipp (1970), Brosgè and Dutro (1973), Holdsworth and Jones (1979), and Dillon and others (1979).

Stratigraphic and structural framework. The Beaver area has map relations that are critical to three major geologic problems: (1) stratigraphic correlation between the southeastern Brooks Range and the east-central Alaska region, (2) the relation of the mafic igneous complexes of the Beaver and Christian quadrangles to adjacent strata of the Ruby geanticline and the southeastern Brooks Range, and (3) the relation between faults inferred to have dominantly strike-slip movement of moderate to large displacement, and faults interpreted as thrusts. The brief summary presented here is based mainly on the maps of Brosge and Reiser cited above. Part of the Beaver area is also discussed by Moore and others (this volume) in the context of the entire Brooks Range orogen.

Three principal rock packages are recognized in the Beaver area: (1) the mafic igneous complexes of the Beaver and Christian quadrangles, (2) low-grade metamorphic rocks of the Ruby geanticline and southeastern Brooks Range, and (3) an intervening belt of dominantly clastic semi-schistose Devonian rocks (figs. 15 and 16).

(1) Mafic igneous complexes of the Beaver and Christian quadrangles--These contain gabbro, diabase, diorite, and basalt of Jurassic and older(?) age (Reiser and others, 1965), intercalated with chert, argillite, tuff, and associated basinal rocks of Mississippian to Permian age (Holdsworth and Jones, 1979). 


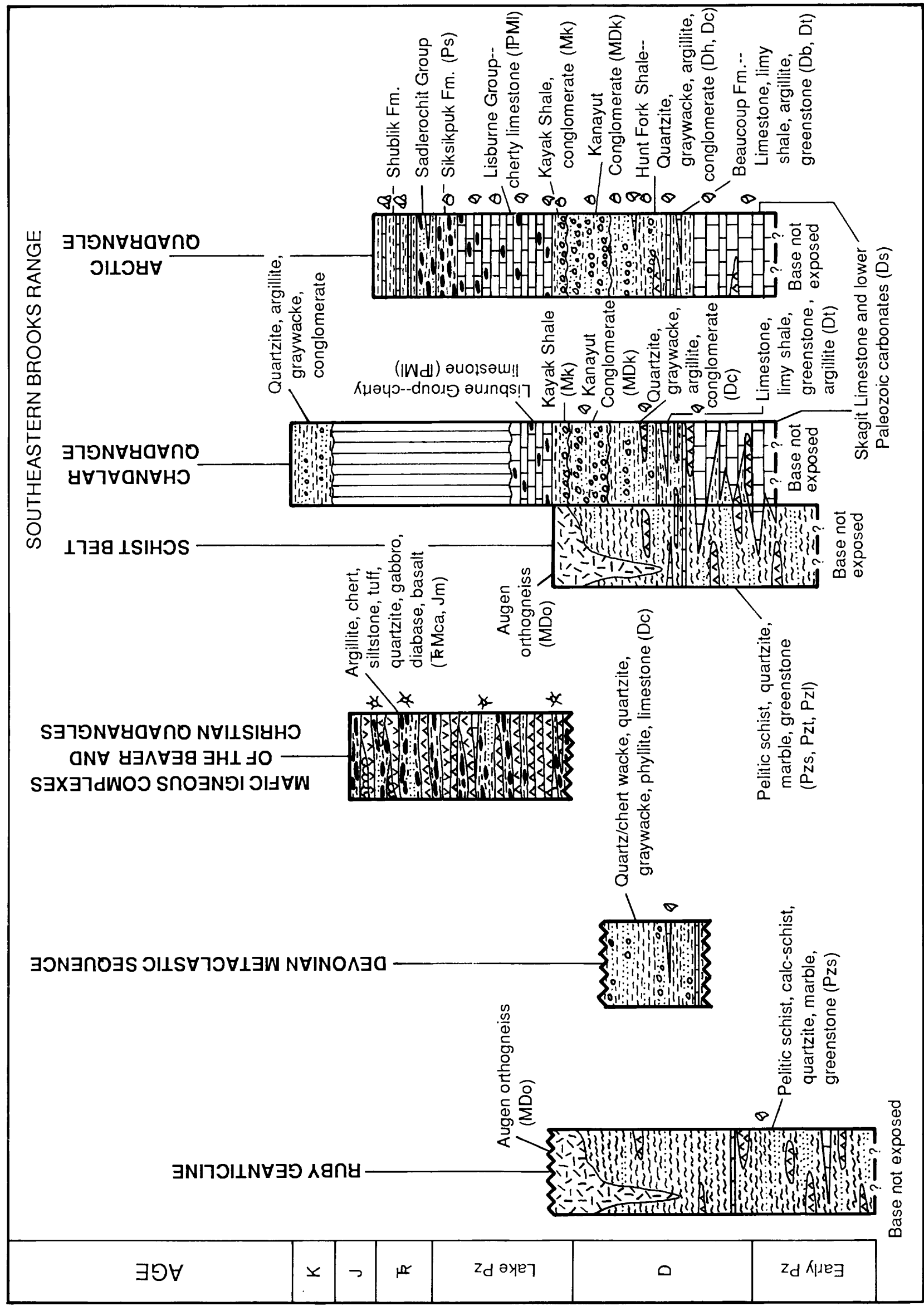


complexes appear from published descriptions to be equivalent in all respects-including lithologic content and age of basinal sedimentary rocks, composition and Mesozoic age of mafic igneous rocks, and stratigraphic and structural position with respect to adjacent rock sequences--to the Rampart assemblage of the Ray Mountains and Livengood areas, and the Circle Volcanics of the Charley River area. Regional correlation of these sequences is implied by the inclusion of all four in the Tozitna terrane of Silberling and Jones (1984).

(2) Low-grade metamorphic rocks of the Ruby geanticline--These rocks, located in the western part of the Beaver quadrangle include pelitic schist, marble, quartzite, calcareous schist, quartzo-feldspathic schist and gneiss, and greenstone; most are low-grade metamorphic rocks of the greenschist facies, but they have medium- to high-grade metamorphic assemblages near the Hodzana and Kanuti batholiths and other granitic plutons (fig. 15). These metamorphic rocks closely resemble those in the metamorphic suite of the Ray Mountains, and they probably formed from the same protoliths. Structural and metamorphic details are not available for this part of the Ruby geanticline. Low-grade metamorphic rocks similar to those of the Ruby genaticline also occur in the "schist belt" along the part of the southern Brooks Range included in the Hammond and Coldfoot subterranes of the Arctic Alaska terrane (fig. 2) of Silberling and Jones (1984). For example, generally low-grade metamorphic and blastomylonitic rocks exhibiting complex fabrics formed by multiple deformation and polyphase metamorphism have been described in the "schist belt" (figs. 15 and 16) by Gottschalk (1987) and Grybeck and Nelson (1981). The Hammond subterrane differs lithologically from the Coldfoot subterrane and the Ruby geanticline in containing locally thick skajit Limestone (Devonian) and lower Paleozoic carbonate rocks. Locally, greenstone and greenschist are abundant and form large mappable masses in both the Hammond and Coldfoot subterranes, just as metabasites do in the Ray Mountains metamorphic suite.

(3) Weakly metamorphosed Devonian clastic rocks--These rocks comprise the Venetie terrane of Silberling and Jones (1984) and occur in a belt that separates the mafic igneous complexes of the Beaver and Christian quadrangles from metamorphic rocks of the Ruby geanticline and the southern Brooks Range. The most characteristic features of these metaclastic rocks are their ferrugenous quartzand chert-rich wacke and lithic graywacke components and their pervasive but incompletely recrystallized blastomylonitic fabric, through which primary sedimentary features and rare invertebrate fossils are preserved. A unit of black phyllitic argillite with subordinate wacke interbeds appears to underlie the coarser clastic rocks. Available thin-sections from rocks of this metaclastic sequence commonly contain more chert clasts than those from rocks of the Devonian metaclastic sequence in the Ray Mountains area, but some sections of quartz-rich siltstone and bimodal quartz-wacke are petrographically indistinguishable from those of the Ray Mountains. The quartz-wacke and graywacke units of the Beaver area (Brosgè and Reiser, 1962, 1964; Brosgè and others, 1973) appear to be mutually gradational and are most likely interbedded; these units are not separated in figure 16. At least partly correlative Hunt Fork shale and Kanayut Conglomerate occur in the Endicott Mountains subterrane of the Arctic Alaska terrane of Silberling and Jones (1984). 
The contacts between the three rock packages described above are shown on figure 15 as thrust faults. In most places, these were mapped as stratigraphic contacts by Brosgè and Reiser (1962, 1964) and Brosgè and others (1973), but structural detachment is interpreted here for most of them, based on map discordances. If correct, analogy with the Ray Mountains area suggests that these detachments may range from thick zones of distributed ductile shear to brittle thrusts, or some complex combination of both. The age of ductile shearing in the Beaver area appears to be bracketed between the Jurassic age of the mafic igneous rocks in the Beaver and Christian complexes, which are locally involved, and the mid-Cretaceous age of the Hodzana pluton (Brosgè and others, 1973), which influenced the crystallization of blastomylonitic fabrics during or just after ductile deformation. If brittle thrusting occurred, it most likely post-dates ductile deformation.

Two zones of right-lateral strike-slip faulting appear to cut east-west across the Beaver area. The southernmost zone, along the north edge of the Beaver quadrangle, contains two main fault strands that displace the east end of the Hodzana pluton, as well as the contacts between the three principal rock assemblages of the Beaver area, right-laterally about $17 \mathrm{~km}$. The eastward continuation of this zone along the north edge of Yukon Flats basin is not exposed, but it may merge with the other major strike-slip zone, which parallels the Chandalar River in the southern Chandalar quadrangle. This zone, here called the Kobuk-Malamute fault zone, is poorly exposed, but it marks a prominent aeromagnetic lineament (Cady, 1978) and a topographic and geologic break between the Ruby geanticline and the schist belt of the southern Brooks Range, along which mafic and associated rocks (Angayucham terrane) at the margin of the Koyukuk basin appear to have been dragged and attenuated. The amount of right-lateral strikeseparation along the Kobuk-Malamute zone is uncertain. However, it could be $80 \mathrm{~km}$ or more if the more eastward position of the mafic igneous complex of the Christian quadrangle compared with that in the Beaver quadrangle represents strike-separation of an originally straighter belt of mafic complexes that was connected.

Discussion. Three observations of Brosgè and Reiser (1973) in their descriptions of map units in the Beaver area suggest that the Devonian metaclastic sequence of the Beaver area shares or overlaps in metamorphic and lithologic characteristics with adjacent metamorphic sequences and with the mafic igneous complexes of the Beaver and Christian quadrangles:

(1) Although most exposures of the Devonian metaclastic sequence are weakly to strongly blastomylonitic, western exposures are more coarsely schistose and appear to grade into schistose rocks typical of the Ruby geanticline and the schist belt. This gradation is especially evident near the Hodzana and Kanuti batholiths in the Ruby geanticline, and west of the Chandalar River in the Chandalar and Christian quadrangles.

(2) The Devonian clastic rocks of the Endicott Mountains and Hammond subterranes and the Venetie terrane in the Chandalar and Christian quadrangles are similar to one another in their lithologic range and content of distinctive rock types. Based on the map distribution of these units, their variably recrystallized fabrics, and sparse fossil evidence, Brosgè and Reiser (1962, 1964) 
considered at least some of the metamorphic rocks of the schist belt to be more thoroughly and coarsely recrystallized low- to medium-grade metamorphic equivalents of the Devonian clastic sequence. If correct, the terrane boundary between the Devonian clastic sequence and rocks of the adjacent schist belt may be primarily a metamorphic transition.

(3) Graywacke and quartzite like that of the Devonian clastic sequence locally intergrade with cherty rocks assigned to the mafic igneous complexes of the Beaver and Christian quadrangles. Brosgè and others (1973) also note places in the Christian quadrangle where these mafic rocks intrude and include Devonian metaclastic rocks.

These three observations heighten the similarity between the Beaver and Ray Mountains areas. They also support the possibility that the three principal rock packages here, as in the Ray Mountains area, may be structurally disrupted sequences that originally had stratigraphic continuity.

\section{Coleen area}

As defined here, the Coleen area includes the Coleen and most of the Table Mountain and Black River 1:250,000 quadrangles, and spans contiguous parts of the southeastern Brooks Range (Moore and others, in press) and the part of the eastcentral Alaska region containing the Porcupine platform (fig. 3 ).

Previous work. The earliest reconnaissance work in the Coleen area was by Kindle (1908), Cairnes (1914), and Maddren and Harrington (1955). Preliminary geologic maps at a scale of $1: 250,000$ were published for the Coleen quadrangle by Brosgè and Reiser (1969), for the Black River quadrangle by Brabb (1970), and for the Table Mountain quadrangle by Brosgè and others (1976). A detailed geologic traverse along the Porcupine River (Brosgè and others, 1966) supplements reconnaissance mapping in the Coleen quadrangle, and the geologic map of the Black River quadrangle (Brabb, 1970) incorporates unpublished mapping by geologists of the British Petroleum Exploration Company and Louisiana Land and Development Corporation. Numerous regional stratigraphic reviews discuss the stratigraphy of the Coleen area, including those by Laudon and others (1966), Churkin and Brabb (1968), Brosgè and others (1962), Brosgè and Dutro (1973), Dutro (1979), and Dutro and Jones (1984).

Stratigraphic framework. The Brooks Range and Porcupine platform parts of the Coleen area have important similarities in their stratigraphic and structural frameworks, as well as the differences emphasized by terrane subdivision. For example, the coleen quadrangle combines critical stratigraphic and structural relationships of the Table Mountain quadrangle, representative of the Brooks Range orogen, with those of the Black River quadrangle, representative of the northern Canadian Cordillera. The stratigraphy of the Coleen quadrangle is divided by Brosgè and Reiser (1969) into four sequences, named the (1) Christian River, (2) Brooks Range, (3) Strangle Woman Creek, and (4) Porcupine River sequences (figs. 17 and 18). 


\section{EXPLANATION}

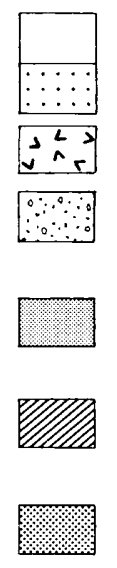

Qd

Ts

Quaternary deposits, undivided

Tertiary sedimentary rocks, undivided

Basalt (Quaternary and Tertiary)

Sandstone and shale (Cretaceous and Jurassic)

JPC Chert, argillite, and sandstone (Jurassic to Permian)

Ks Shublik Formation (Triassic)--Calcareous shale, limestone and sandstone

ЂPs Sadlerochit Group (Triassic to Permian)-Shale, sandstone, and limestone; includes Permian part of the shale unit (PCs) of Brabb (1970)

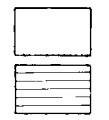

Psc Shale, chert, and sandstone (Permian)

IPMI Lisburne Group (Pennsylvanian and Mississippian)--Cherty limestone

Shale, argillite, quartzite, conglomerate, and limestone (Mississippian)

Mk Kayak Shale and Kekiktuk Conglomerate, undivided

MDk Kanayut Conglomerate (Lower Mississippian? and Upper Devonian)

Dhf Hunt Fork Shale (Upper Devonian)-Mapped only in southwest corner of Table Mountain quadrangle

Semi-schistose metaclastic rocks and phyllite (Devonian and older?)-Includes the informal phyllite (Pzp), quartzite $(\mathrm{Pzq})$, and metamorphic rock $(\mathrm{Pzm})$ units of Brosge and Reiser (1969), and phyllite (Pzp), quartzite (Pzp€q), and schist (Pzp€s) units of Brosge and others (1976)
Dvs Bimodal volcanic rocks and greenstone (Devonian?)

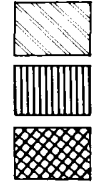

DSI

Limestone (Devonian and Silurian)

o€l Limestone (Ordovician and Cambrian)

OZn Neruokpuk Formation of Norris (1985)

(Late Proterozoic?)--Chert and phyllite

$€ \mathrm{\epsilon Zt}$

Upper part of the Tindir Group (Cambrian and Late Proterozoic)--Argillite, quartzite, limestone, and dolomite

Intrusive and Related Extrusive Rocks

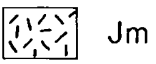

Gabbro, quartz diorite, and basalt (Jurassic)

E\#/ $\mathrm{MDgr}$

Granitic rocks (Mississippian to Devonian, and younger?)--Includes rhyolite

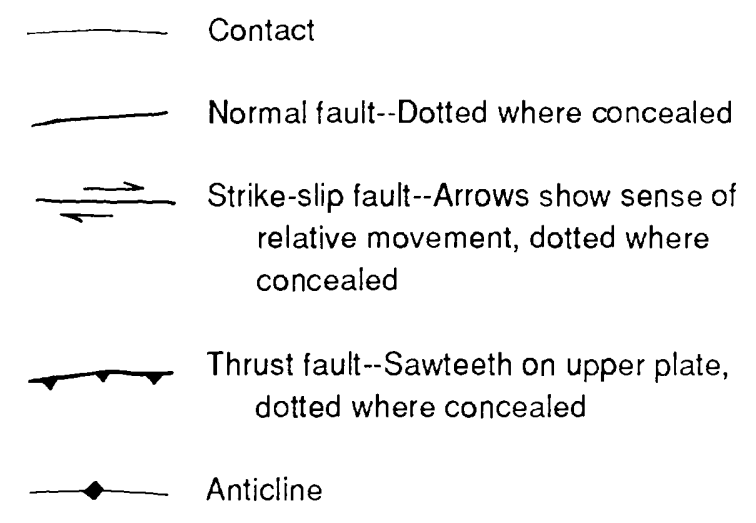

Eigure 17.--Geologic map of the coleen area. See figure 3 for area 


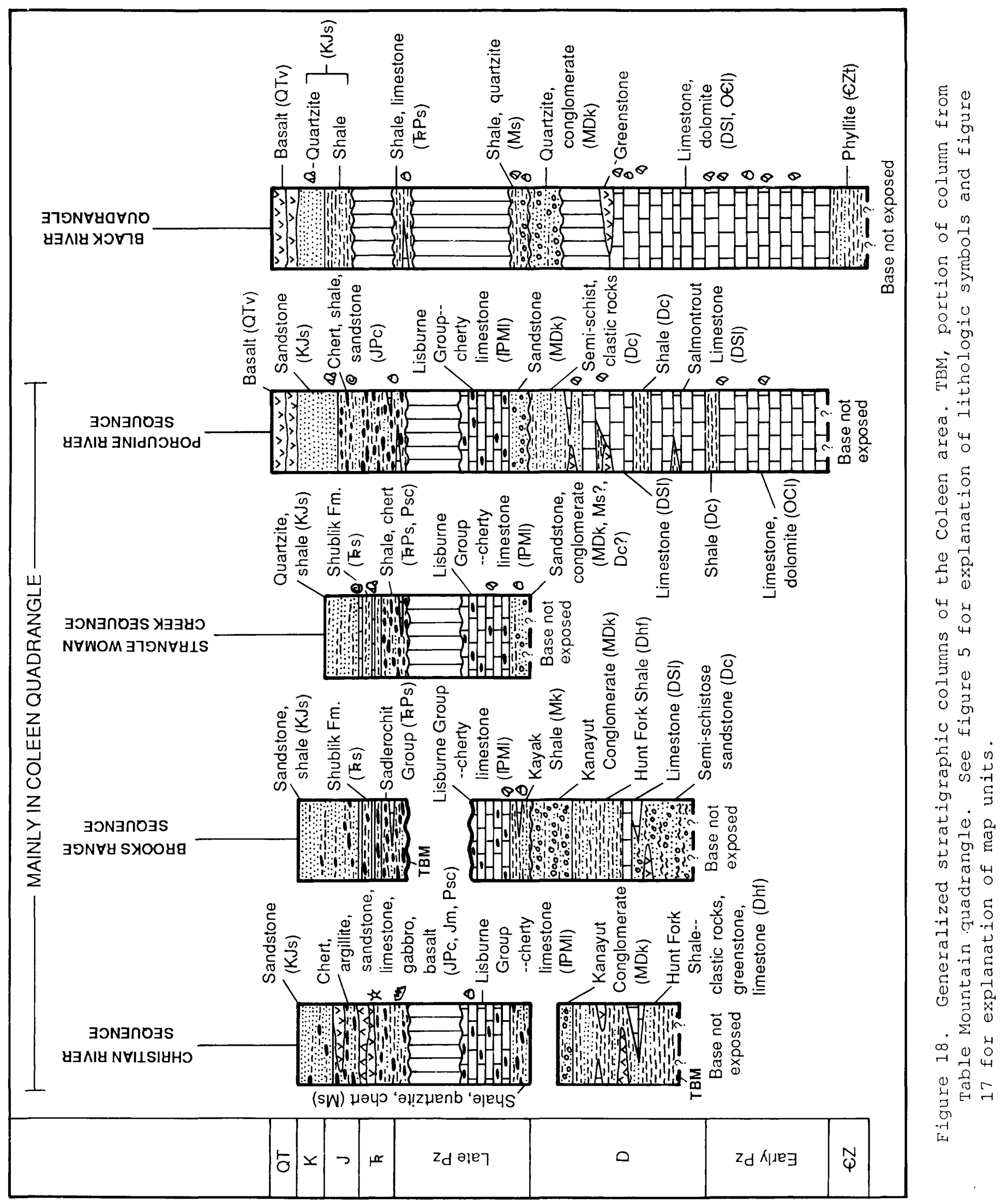


(1) Christian River sequence--This sequence contains a basinal facies of black argillite, sandstone, and varicolored chert of Mississippian to Triassic? age, basalt, and limestone of Mississippian age, all complexly injected by voluminous gabbro, diabase, and quartz diorite sills and dikes (fig. 17). The Christian River sequence is contiguous with, and has a similar range of lithic content and age, as the mafic igneous complexes of the Christian and Beaver quadrangles in the Beaver area, and most of the sequence is assigned by Silberling and Jones (1984) to their Tozitna terrane. The lower part of the Christian River sequence differs from the other mafic igneous complexes in containing interbeds of thin, bioclastic, cherty, Mississippian limestone assigned by Brosgè and Reiser (1969) to the Lisburne Group. The basinal aspect of these limestone interbeds contrasts with the shallow-water platformal facies of the Lisburne that characterizes the adjacent (and underlying?) Brooks Range sequence (Endicott Mountains subterrane of Silberling and Jones, 1984). However, gradations between platformal and basinal facies occur in the Lisburne Group of the Brooks Range (Dutro, 1979; Dutro and Jones, 1984). The occurrence of the Mississippian carbonates appears to have led Silberling and Jones (1984) to designate the lower part of the Christian River sequence as a separate Sheenjek terrane distinct from both the Tozitna terrane and the Endicott subterrane (figs. 17 and 18).

Alternatively, the interbedding of Lisburne limestone at the base of a maficinjected and otherwise Tozitna-like sequence could be interpreted as lithologic intergradation between the Christian River and Brooks Range sequences (and between their equivalent terranes). Unconformably overlying the Mississippian limestone in the lower part of the Christian River sequence are Permian(?) (to Triassic?) calcareous fine- to medium-grained clastic rocks and chert. In lithology and age, these rocks resemble chert-rich rocks in the Tozitna terrane, as well as chertbearing rocks of the Siksikpuk Formation and Sadlerochit Group, which overlie the Lisburne Group in other sequences and terranes of the Coleen area.

(2) Brooks Range sequence--This sequence is equivalent to the Devonian to Mississippian parts of sequences assigned throughout the Brooks Range by Silberling and Jones (1984) to their Endicott subterrane. The Brooks Range sequence consists of, from oldest to youngest, the Upper Devonian Hunt Fork Shale, Upper Devonian and Lower Mississippian Kanayut Conglomerate, Mississippian Ketiktuk Conglomerate, Mississippian Kayak Shale, and Mississippian and Pennsylvanian Lisburne Group (fig. 18). In the northwest corner of the Coleen quadrangle, and in places within the Table Mountain quadrangle to the north, a more heterogeneous succession of Devonian(?) limestone and volcanic rocks, and Paleozoic(?) semi-schistose ferruginous sandstone, conglomerate, and calcareous sandstone either underlies or interfingers with the Hunt Fork-Kanayut interval. In parts of the Table Mountain quadrangle, typically ferruginous and semischistose clastic rocks are assigned to the schist unit (Pzpes) of Brosgè and others (1976). Correlation of these clastic rocks with the Late Proterozoic Neruokpuk Formation of Norris (1985), found in the easternmost Brooks Range northeast of the Coleen area, is possible; however, map descriptions of them in the Table Mountain quadrangle are most similar in lithologic character, petrologic details, and mylonitic to semi-schistose fabric to units assigned by Brosgè and Reiser (1962, 1964) and Brosgè and others (1973) to the Devonian metaclastic sequence in the Beaver area to the west. 
In the Table Mountain quadrangle, the Lisburne Group of the Brooks Range sequence is overlain by calcareous fine- to medium-grained clastic rocks like those of the Permian to Triassic Sadlerochit Group but yielding Pennsylvanian as well as Permian fossils. In parts of the Arctic quadrangle to the west, Permian and Triassic rocks of the Sadlerochit Group and Siksikpuk Formation overlying the Lisburne there contain bedded chert (Brosgè and Reiser, 1965).

(3) Strangle Woman Creek sequence--This sequence, located in the northeastern Coleen quadrangle, is equivalent to the North slope subterrane of Silberling and Jones (1984), and contains Mississippian limestone of the Lisburne Group and underlying conglomeratic sandstone (correlative with the Kekiktuk Conglomerate?) that lie discordantly on semi-schistose ferruginous quartzite and siltstone, and phyllitic argillite (fig. 17); the contact was mapped by Brosge and Reiser (1969) as an unconformity, but it also appears to mark a metamorphic break and may be a zone of structural detachment as well. The semi-schistose clastic rocks can be traced into those of the Brooks Range sequence in the Table Mountain quadrangle, but they are assigned to the Paleozoic here, based on the occurrence of fossil snails in a float block of the quartzite.

Unconformably overlying the Lisburne Group of the Strangle Woman Creek sequence in the Coleen area are questionably identified Jurassic quartzite and shale. Locally, chert and shale of Permian(?) (and Triassic?) age, and at one locality, calcareous shale, sandstone, and limestone assigned to the Triassic Shublik Formation are mapped beneath the Jurassic rocks (Brosgè and Reiser, 1969). In the northern Table Mountain quadrangle, the Lisburne Group is overlain by lithologically similar fine- to medium-grained clastic rocks and limestone of the Sadlerochit Group (Permian and Triassic) and Shublik Formation (Triassic) (Brosgè and others, 1976).

Jurassic(?) mafic rocks like those in the Christian River sequence occur locally within the Strangle Woman Creek sequence. They intrude carbonates of the Lisburne Group in the northeastern part of the Coleen quadrangle, and Permian to Jurassic clastic rocks associated with the Shublik Formation near the contact with the Christian River sequence in the center of the quadrangle.

The Strangle Woman Creek sequence is intruded by the old Crow batholith, which contains Carboniferous granitic rocks yielding $\mathrm{K}-\mathrm{Ar}$ biotite and muscovite ages of $295 \pm 9 \mathrm{Ma}$ to $335+10 \mathrm{Ma}$ (Brosgè and Reiser, 1969), and associated felsic volcanics or metavolcanics. These suggest a middle to late Paleozoic igneous event corresponding to that recognized in the core of the Brooks Range orogen (Dillon and others, 1980), in the Ruby geanticline, and in the Yukon-Tanana upland. However, the Paleozoic age of the old Crow batholith is in question, because the batholith: (a) appears to discordantly cut the Jurassic quartzite and shale unit; (b) cuts off faults that are interpreted from map patterns to be thrusts, which throughout the east-central Alaska and southeastern Brooks Range region are no older than late Mesozoic; and (c) appears to upgrade incompletely recrystallized semi-schistose rocks of the Strangle Woman Creek sequence to biotite and garnet schist near its contact, a relationship reminiscent of the influence of Cretaceous plutons on the Devonian metaclastic sequence of the Beaver area. These contact relations raise the question of whether the old Crow batholith may have been remobilized during regional heating in the Cretaceous, or 
whether the batholith might be a Cretaceous one in which the mid-Paleozoic age is inherited.

(4) Porcupine River sequence--This sequence is equivalent to the Porcupine terrane of Silberling and Jones (1984). It contains a dominantly carbonate succession in its lower and middle Paleozoic parts (fig. 18) that is not present in sequences (1) to (3). This succession represents a carbonate platform that is best and most completely developed in the northeastern Black River quadrangle (Brabb, 1970). Sedimentological and biostratigraphic aspects of the Porcupine platform are discussed by Churkin and Brabb (1968), Brosgè and Dutro (1973), Lane and Ormiston (1979), and Coleman (1985). Abundantly fossiliferous beds of the Lower or Middle Devonian Salmontrout Limestone occur in the lower part of the Porcupine platform sequence. Lower Devonian beds lithologically and biostratigraphically equivalent to part of the Salmontrout Limestone occur in the McCann Hill Chert (Churkin and Carter, 1970) and Ogilvie Formation of Clough (1980) in the Charley River area, and in the Schwatka stratigraphic assemblage of the Livengood area (R.B. Blodgett, written commun., 1987). Carbonate rocks coeval with older and younger parts of the Porcupine platform sequence are represented in the Silurian to Middle Devonian Tolovana Limestone of the White Mountains stratigraphic assemblage in the Livengood area, and in Middle to Upper Devonian and older carbonate beds assigned to the variably metamorphosed Skajit Limestone of the southern Brooks Range (Brosgè and Reiser, 1964; Nelson and Grybeck, 1980).

Above the Upper Ramparts of the Porcupine River, Brosgè and others (1966) traversed a succession of carbonate and clastic rocks originally considered to be Precambrian(?) in age, but which were later assigned to the Paleozoic(?) in the Coleen quadrangle (Brosgè and Reiser, 1969). The pattern of repetition of these units strongly suggests imbricate thrusting of the sequence. The clastic rocks consist of locally blastomylonitic ferruginous quartzite, sandstone, and shale, which track northwestward into a broad area of poor exposures that abuts the Strangle Woman and Christian River sequences. Laterally equivalent clastic rocks in adjacent Yukon Territory are questionably assigned to the Late Proterozoic. However, the wide distribution of similar rocks that are locally fossiliferous in the southeastern Brooks Range raises the alternative possibility that these clastic rocks are part of a regional Devonian metaclastic package that unconformably overlies the Paleozoic carbonates and participated in older-onyounger thrusting in the upper Porcupine River area. Imbricate thrusting is also evident from the pattern of stratigraphic repetition in the western part of the Porcupine River traverse of Brosge and others (1966), where upper Paleozoic units are involved in addition to the middle and lower Paleozoic parts of the section.

Carboniferous and younger strata of the porcupine River sequence resemble those of sequences (1) to (3), except that the Lisburne Group and rocks of Triassic age are not identified. However, cherty limestone and shale like that characteristic of the Lisburne is present in two sections measured by Brosgè and others (1966); in neither case is the top exposed. The Carboniferous to Jurassic clastic rocks overlie Paleozoic strata of the Porcupine River sequence.

Jurassic(?) mafic rocks appear from map patterns to intrude Devonian carbonates and associated clastic rocks of both late and early paleozoic age in 
the Porcupine River sequence. The mafic intrusives are abundant in places, mainly north of the Porcupine River.

Structure. The boundaries of the four stratigraphic sequences of the Coleen area are poorly exposed, but some are shown as faults on existing maps (Brosgè and Reiser, 1969). The map evidence for sequence-bounding faults is equivocal.

The part of the Table Mountain quadrangle containing a thick Lisburne carbonate section and associated shaly units is characterized by a fold-and-thrust belt deformational style that is representative of the central and eastern Brooks Range. Most imbricate thrusts appear to splay from weak shaly zones of structural detachment, the main one being within the Mississippian Kayak Shale. Bundles of generally east-west-trending imbricate thrust faults bend southeastward toward, and apparently merge with, several northeast-trending topographic lineaments in the southern Table Mountain and northern Coleen quadrangles (fig. 17). Neither the lineaments nor the thrust bundles can be traced beyond their points of mutual convergence. The lineaments appear to track southwestward into the Kobuk-Malamute fault zone of the Beaver area.

Faults interpreted as thrusts in the southeastern Coleen and northeastern Black River quadrangles have northeast trends paralleling those mapped by Norris (1984) in adjacent parts of northern Yukon Territory. The thrusts are cut by high-angle faults with more linear or curvilinear northeast trends and for which normal dip-slip (extensional) displacements are inferred. Among the most prominent of these are the Yukon and Kaltag faults of Norris (1984), which have mapped lengths of 100 to $200 \mathrm{~km}$. Some of the high-angle faults may have a strikeslip component of movement, but none appear to be through-going features that produce any significant lateral offset of pre-existing thrusts. They may, however, represent long-lived crustal fractures that intermittently influenced basin formation and sedimentation.

THE GEOLOGY OF EAST-CENTRAL ALASKA IN AN INTERREGIONAL CONTEXT

Most of the geologic features and problems identified in the foregoing summaries either involve the east-central Alaska region as a whole or are interregional in scope. In this section of the report, several key topics are discussed in an interregional context that draws on data and interpretations in adjacent regions of Alaska and Canada, as well as on the descriptive summaries of east-central Alaskan geology.

\section{Terrane subdivisions and paleogeographic setting--a regional stratigraphic perspective}

The geology of east-central Alaska has been subdivided into numerous tectonostratigraphic (lithotectonic) terranes in recent publications (see for example, Coney and others, 1980; Jones and others, 1981, 1983, and 1987; Dutro and Jones, 1984; Howell and others, 1987; Silberling and others, in press). An 


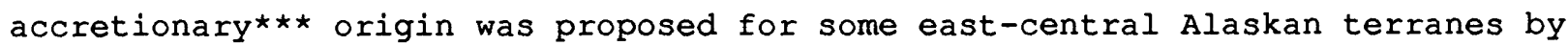
Churkin and others (1982) and accretion is indicated for all Alaskan terranes according to the usage of Silberling and Jones (1984) and Jones and others (1987). There is no question that east-central Alaska has undergone severe structural disruption. Most terrane boundaries here are either thrust faults or strike-slip faults. In evaluating the significance of these terranes, the most important questions are: (1) whether any of the terranes represent accretionary sequences that originated beyond the North American depositional margin, and whether any of the terrane-bounding structures represent fundamental sutures; or alternatively, (2) whether the terranes are compatible within a reasonably reconstructed North American paleostratigraphic framework.

In considering the stratigraphic framework of east-central Alaska, a continuity of generally coeval stratigraphic packages is more apparent for the region as a whole than is obvious from the study of stratigraphic details in local areas. Despite the stratigraphic differences emphasized by tectonostratigraphic terrane subdivisions, many threads of stratigraphic continuity and similarity are apparent from area to area and terrane to terrane in the foregoing geologic summaries. The similarities between many terranes are at least as impressive as the differences, and these similarities are of critical significance in evaluating relations among terranes. Furthermore, it seems clear that stratigraphic differences caused by facies variations and unconformities within some individual terranes are as great as those between terranes (for example, see Dover, in press; Brosgè and Dutro, 1973; Thompson and Roots, 1982; Dutro and Harris, 1987).

Correlation and North American affinity of rocks and terranes in the Charley River and Livengood areas.

Eastern Charley River area--The lithologic content and sequence of stratigraphic units in the eastern part of the Charley River fold-and-thrust belt are remarkably similar to those of the Middle Proterozoic to Triassic North American miogeoclinal succession exposed farther east in Canada. There are some obvious stratigraphic differences between the Charley River area and adjacent Yukon Territory (Jones and others, 1987), and facies variations are locally prominent, as should be expected for any depositional realm as extensive and complex as the Cordilleran miogeocline. Nevertheless, numerous key units of the eastern Charley River fold-and-thrust belt (fig. 5) can be correlated with units in Yukon Territory of unquestioned North American origin (also see TempelmanKluit, 1984). Among these correlations are:

(1) interfingering shale and stromatolitic limestone of the Middle Proterozoic lower part of the Tindir Group (Eberlein and Lanphere, in press), with

\footnotetext{
$\star \star \star$ The term "accretion" as used in this chapter means continental growth by the addition of "exotic" material that originated external to the craton and its pericratonal depositional prism, usually by convergent plate-tectonic processes. This usage excludes the juxtaposition of continental material tectonically dispersed from one part of a continental margin to another, either by strike-slip faulting or by telescoping on thrust faults.
} 
the upper part of the Wernecke Supergroup of east-central Yukon Territory (Delaney, 1981);

(2) basaltic volcanic and volcaniclastic rocks and associated rocks of the Lower Cambrian and(or) Late Proterozoic upper part of the Tindir Group, with the Mount Harper volcanic complex of Thompson and Roots (1982), Roots and Moore (1982), and Roots $(1983,1988)$ in the Dawson quadrangle;

(3) graptolitic shale and chert of the Lower Devonian to Lower Ordovician Road River Formation, with the Road River Formation and correlative rocks of Selwyn basin and northern Yukon Territory (see discussion in Cecile, 1982, p. 1923);

(4) Ogilvie Formation of Clough (1980) and coeval Lower to Middle Devonian limestone in the lower part of the McCann Hill Chert, with the Ogilvie Limestone of the Dawson quadrangle (Clough and Blodgett, 1984);

(5) thick quartzite- and chert-rich coarse clastic rocks of the Nation River Formation (Upper Devonian), with coeval parts of the Earn Group, thought by Gordey and others (1987) to be derived from local uplifts of lower Paleozoic quartziteand chert-bearing rocks within the outer part of the Cordilleran miogeocline, and with the Imperial Formation of northern Yukon Territory (Gordey and others, 1987);

(6) Ford Lake Shale (Upper Mississippian to Upper Devonian), with strata assigned to the same unit in central Yukon Territory (Norris, 1984);

(7) Calico Bluff Formation (Lower Pennsylvanian and Upper Mississippian), with the Hart River Formation (Bamber and Waterhouse, 1971);

(8) Permian Tahkandit Limestone and Step Conglomerate, with the Tahkandit Limestone and Jungle Creek Formation of central Yukon Territory (Norris, 1984); and

(9) Kandik Group (Lower Cretaceous) and upper part of the Glenn Shale (Jurassic), with coeval foreland basin deposits of northern Yukon Territory and the north slope of the Brooks Range (Young, 1973; Norris, 1984).

Western Charley River area--The regional correlation and paleogeographic significance of rocks in the terranes proposed by Silberling and Jones (1984) and Churkin and others (1982) for the western Charley River area (fig. 5) are less obvious. Churkin and others (1982) interpreted the Woodchopper Canyon, Slaven Dome, and Circle terranes as oceanic fragments that were accreted to North America. Their interpretation was based on the basinal character of the middle to upper Paleozoic fine-grained siliciclastic rocks and cherts, and on the abundance of associated mafic volcanic and plutonic rocks. Alternatively, I suggest that all of these rocks originated in rifts or extensional basins within the outer part of the middle to late Paleozoic Cordilleran miogeocline and were imbricated with coeval carbonate and clastic strata by thrusting within the Charley River foldand-thrust belt. 
The stratigraphic evidence supporting a North American intracontinental rift origin for the western Charley River terranes is that all of them, including those with oceanic-like rocks, contain units similar in lithology and age to units of North American miogeoclinal affinity in the eastern part of the Charley River area and in Yukon Territory. The Takoma Bluff terrane of Churkin and others (1982) contains poorly dated Late Proterozoic rocks similar to those in the upper part of the Tindir Group, and clastic rocks resembling the Upper Devonian Nation River Formation of the eastern Charley River sequence. Black carbonaceous to siliceous argillite and chert of late Paleozoic age in the circle terrane of churkin and others (1982) and the corresponding Tozitna terrane of Silberling and Jones (1984) are lithologically similar to parts of the Ford Lake Shale (Upper Mississippian to Upper Devonian) and Calico Bluff Formation (Lower Pennsylvanian and Upper

Mississippian) of the eastern Charley River area, and to fine-grained parts of the Earn Group (Gordey and others, 1987). Additional correlations with rocks of central Yukon Territory suggested by Tempelman-Kluit (1984) are: (1) the Woodchopper Canyon terrane of Churkin and others (1982) with the Marmot Volcanics of Cecile (1982) in the Misty Creek embayment of Selwyn basin, and (2) chertpebble conglomerate and associated clastic deposits of the Slaven Dome terrane of Churkin and others (1982) with the Upper Devonian Nation River Formation in the eastern Charley River fold-and-thrust belt, and with the Earn Group (Gordey and others, 1987). Major differences in the amount of local downcutting by unconformities and the abruptness of facies variations characterizing parts of the eastern Charley River stratigraphic succession, combined with the lack of evidence for contractional deformation of pre-Mesozoic age, indicate that Late Proterozoic to Permian deposition was influenced by intermittently active pre-thrusting highangle faults that controlled basin subsidence and block uplift of local source areas (Gordey and others, 1982 and 1987; Dover, in press). A Late Proterozoic and Paleozoic extensional environment like that envisioned for the Canadian Cordillera by Thompson and Eisbacher (1984), Thompson and others (1987), Gabrielse and Yorath (1987), and Struik (1987) would be expected to produce the kinds of contrasting rock sequences that are structurally juxtaposed in the "terranes" of the western Charley River area. Rocks with oceanic affinity are inferred to have formed in the most dilated of the extensional basins.

The structural evidence against an accretionary origin for any of the terranes of the western Charley River area is that the style of the thrust faults that bound them, and the degree of internal deformation and shortening within them, are comparable to the style and intensity of deformation characterizing thrust-bounded sequences in the eastern part of the Charley River fold-and-thrust belt, where individual thrusts are interpreted to have displacements of $10 \mathrm{~km}$ or less. None of the western Charley River area thrusts, either individually or as a group, appear to be sutures in the the sense required by the accretionary model. Conversely, the existence of the Charley River fold-and-thrust belt provides a ready explanation for facies telescoping without invoking accretionary tectonics.

Livengood area--As the geologic summary of the Livengood area illustrates (figs. 8 and 9), numerous lithologic similarities exist among the stratigraphic belts (and corresponding terranes designated by Silberling and Jones, 1984) recognized there. Six of the eleven stratigraphic belts have a basement composed of the Wickersham grit unit. These are the Wickersham, White Mountains, Livengood, Schwatka, and Crazy Mountains belts, and the Preacher block. At least 
five of the stratigraphic belts contain chert-rich, locally derived polymictic conglomerates of probable middle to late Paleozoic age. These are the White Mountains, Beaver, Livengood, and Crazy Mountains belts, and the Minook terrane. Basaltic volcanic and locally differentiated mafic intrusive rocks, thought to represent volcanic/plutonic centers of at least three distinct ages, occur in several of the stratigraphic belts of the Livengood area. The heterogeneous and mafic/ultramafic unit of the Livengood stratigraphic belt is interpreted as a Late Proterozoic to Cambrian mafic volcanic/plutonic center comparable to those in extensional intracontinental North American settings farther east, such as the upper part of the Tindir Group and the Mount Harper complex (see Roots, 1988). Another center, represented by the Fossil Creek Volcanics of Ordovician age in the White Mountains stratigraphic belt, probably correlates with mafic volcanic rocks in unit II of Thompson and Roots (1982) in the Dawson quadrangle, and with the more sparsely volcanic Livengood Dome Chert in the Livengood stratigraphic belt (fig. 9). The third mafic volcanic/plutonic center consists of the volcanics of probable Early to Middle Devonian age in the Schwatka stratigraphic belt. These most likely correlate, at least in part, with the woodchopper volcanics of the Charley River area.

No tectonic melange, relict accretionary prism, or other evidence of crustal suturing is evident in any of the stratigraphic belts of the Livengood area. On the contrary, the thrusts bounding these belts, and their styles of internal folding and imbrication, resemble fold-and-thrust belt styles in the Charley River area and adjacent Yukon Territory. Most of the stratigraphic belts (and equivalent "terranes") of the Livengood area seem best interpreted as thrustbounded sequences of North American origin, whose lithologic differences resulted from facies telescoping of limited extent, analogous to that in the Charley River fold-and-thrust belt. The thrusted sequences were further segmented and dispersed by later strike-slip faulting. Ductility contrasts and differences in metamorphic character between some stratigraphic belts may have resulted from the juxtaposition of different crustal levels by fold-and-thrust belt telescoping and differential uplift associated with strike-slip movement.

Regional geologic ties between the Ray Mountains and Beaver areas, the southeastern Brooks Range, and adjacent areas.

Metamorphic rocks--The protolithic model for the metasedimentary rocks and metabasites in the metamorphic suite of the Ray Mountains (fig. 14) infers deposition and mafic intrusion in an intermittently extending, distal part of a depositional wedge like that characterizing the Late Proterozoic through middle Paleozoic Cordilleran miogeocline. These metasedimentary rocks appear to be representative of the Ruby terrane of Silberling and Jones (1984) as a whole. Granitic plutons generated from continental crust were emplaced in the sedimentary protolith in Devonian time, prior to the culminating deformational, metamorphic, and plutonic events in Jurassic to mid-Cretaceous time.

The rocks of the Ruby terrane resemble those of the schist belt of the southern Brooks Range (and its terrane equivalents). A direct connection between the two has long been suspected but not proved (Patton and others, 1987). Rocks of the schist belt described by Dillon and others (1980, 1985, 1986), Nelson and Grybeck (1980), Karl and Long (1987), Gottschalk (1987), and Till and others 
(1987) resemble those in the metamorphic suite of the Ray Mountains in lithic content, protolith, fabric and structural sequence, and the occurrence of Upper Devonian to Lower Mississippian augen orthogneiss. An older episode of Precambrian metamorphism is recognized locally in the western Brooks Range (Turner and others, 1979); probable precambrian metamorphic rocks also occur locally in the Ruby terrane southwest of the Ray Mountains (Silberman and others, 1979b). The Ruby terrane and schist belt differ in that the part of the Ruby terrane north of the Kaltag fault has a vastly greater volume of mid-Cretaceous granitic rocks then the schist belt, where Cretaceous plutonism has not been demonstrated (Miller, in press); Cretaceous plutonism is also relatively sparse in the Ruby terrane south of the Kaltag fault.

All of the lithic components of the Ray Mountains metamorphic suite also have close counterparts within the Yukon-Tanana upland (fig. 19; Foster and others, 1987, and this volume). Comparable blastomylonitic fabrics, deformational style and sequence, and paragenetic relations of polymetamorphic mineral assemblages have been described in the Yukon-Tanana upland by Laird and Foster (1984), Cushing (1984), Cushing and Foster (1984), Cushing and others (1982), Dusel-Bacon and Foster (1983), and Foster and others (1987, and this volume). Middle Devonian to Early Mississippian augen orthogneiss (Dusel-Bacon and Aleinikoff, 1985) and midCretaceous granitic rocks of the Yukon-Tanana upland are indistinguishable from those in the Ray Mountains. Some siliciclastic rocks of the Yukon-Tanana upland that are as young as Permian and contain mafic/ultramafic rocks (fig. 19) have no recognized counterparts in the metamorphic suite of the Ray Mountains, but less metamorphosed lithologic equivalents of that age occur in the Rampart assemblage.

Devonian metaclastic sequence--The variably metamorphosed Devonian clastic rocks along the southeast side of the Ruby geanticline represent a particularly important tie between the Ray Mountains area and parts of the southeastern Brooks Range in the Beaver and possibly the Coleen areas. These typically mylonitic to semi-schistose Devonian metaclastic rocks were originally correlated by Brosgè and Reiser (1962, 1964) throughout the area that is now subdivided into the Venetie, Coldfoot, and Hammond subterranes by Silberling and Jones (1984). The lithologic grounds for the original correlations are still valid, and metamorphic variations within the metaclastic unit are gradational in most places, and cross subterrane boundaries. Furthermore, the metaclastic sequence contains all the lithic components, including quartz- and chert-rich conglomerates and black argillaceous rocks, that characterize the middle Paleozoic part of the Brooks Range sequence in the Endicott Mountains subterrane of Silberling and Jones (1984), which contains the Upper Devonian Hunt Fork Shale, Upper Devonian and Lower Mississippian(?) Kanayut Conglomerate, Lower Mississippian Kekiktuk Conglomerate, and Mississippian Kayak Shale. The lithologically similar Eaxn Group of the northern Canadian Cordillera has a range of Devonian to Mississippian age encompassing that of the Devonian metaclastic sequence, as well as that of the Nation River Formation and the Cascaden Ridge unit in several sequences and terranes of the Charley River and Livengood areas. All of these clastic rocks can be considered as parts of a regionally developed but locally variable sequence of Devonian clastic rocks that overlapped the outer part of the Cordilleran miogeocline as it underwent intermittent fault-controlled basin subsidence and block uplift (Gordey and others, 1987). 


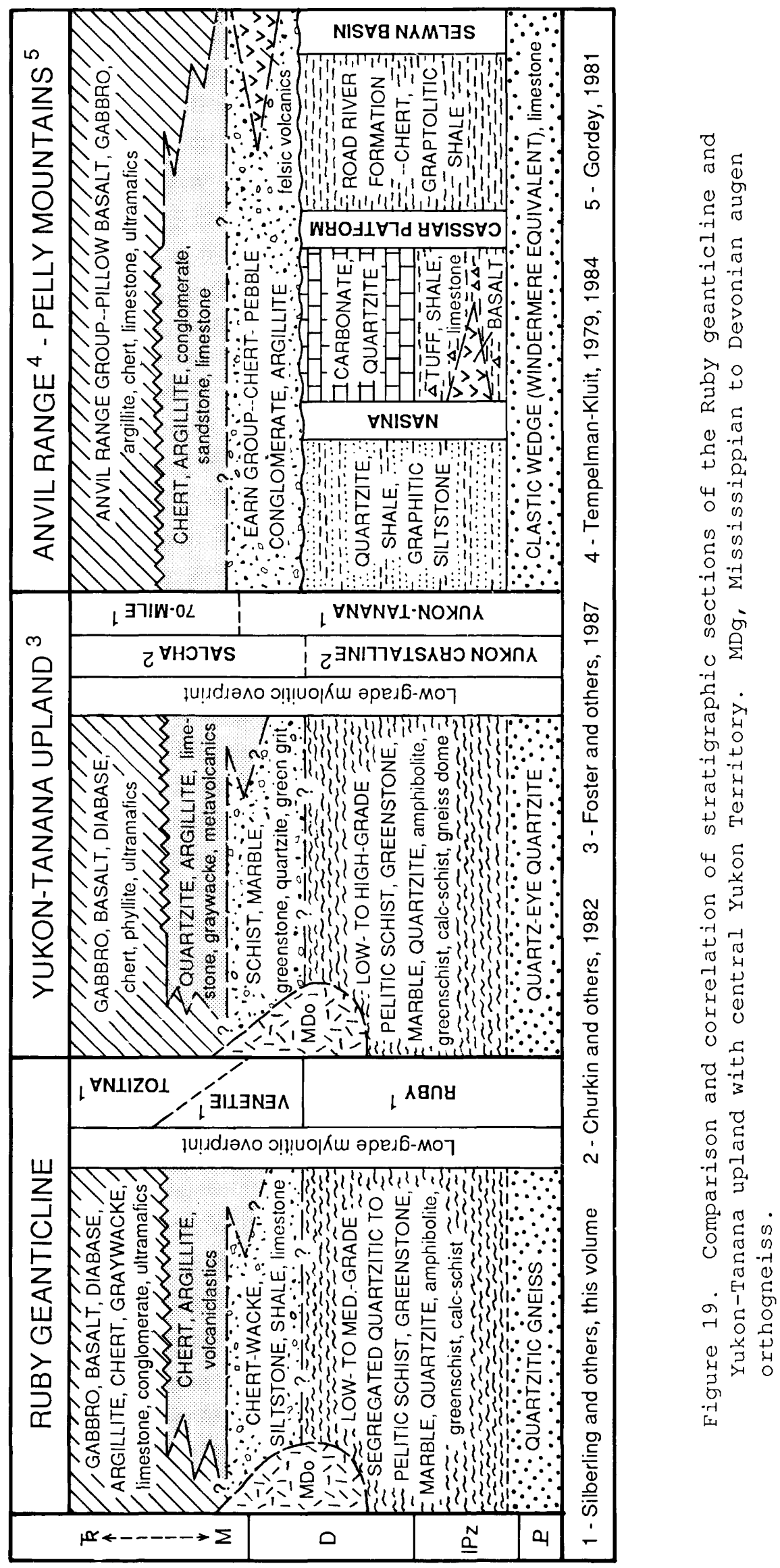


If the semi-schistose clastic rocks of the Coleen area are indeed Devonian, then the stratigraphic similarities between the Brooks Range and Strangle Woman River sequences (and the equivalent terranes of Silberling and Jones, 1984) are compelling, and their differences can be attributed to minor facies variations and unconformities, just as comparable differences have been explained in the eastcentral Alaska region. The likelihood that the Sheenjek terrane of Silberling and Jones (1984) represents lithologic interfingering between basinal sediments of the mafic-rich Christian River sequence and a basinal facies of Lisburne limestone (Mississippian and Pennsylvanian) of the Brooks Range sequence bears on the origin of the Tozitna terrane, discussed below.

Other correlations involving units of the Coleen area--The Porcupine River sequence differs stratigraphically from the Christian River, Brooks Range, and Strangle Woman Creek sequences in some important ways, but it does not appear to be separated from them by a major structural discontinuity. Its boundary is irregular, and available mapping reveals no single through-going structural zone, such as the hypothetical "Porcupine lineament" (Churkin and Trexler, 1980, 1981), separating it from the others. The "Kaltag" fault of adjacent Yukon Territory (Norris, 1984) projects into the porcupine sequence, and is not a bounding megastructure along its north edge. Significantly, semi-schistose clastic rocks like those elsewhere in the Coleen area appear to overlie the lower Paleozoic carbonate section of the Porcupine sequence. If so, and if all of these clastic rocks are Devonian, then lower Paleozoic platform carbonates equivalent to those of the Porcupine sequence could be present in the subsurface under the clastic unit in the other sequences of the Coleen area.

Heterogeneous volcanic-bearing Devonian rocks in the Brooks Range sequence of the Coleen area appear to have lithologic equivalents in volcanic-bearing parts of the schist belt farther west, in the southern Wiseman and Chandalar quadrangles (Dillon and others, 1986; Brosgè and Reiser, 1964). These not only resemble rocks of the Ambler sequence of the southwestern Brooks Range, for which a rift origin is inferred (Hitzman and others, 1982 and 1986), but also have lithologic counterparts farther north in the Brooks Range (Dutro and others, 1977), in the Woodchopper Volcanics and the Schwatka belt of the Charley River and Livengood areas, and in parts of the northern Cordilleran miogeocline in southern Yukon Territory (Mortensen and Godwin, 1982). The age and character of sediment-hosted volcanogenic mineral deposits in rift-controlled sequences of the the Ambler district of the southwestern Brooks Range are also similar to deposits in comparable settings of the Selwyn basin in southern Yukon Territory (Einaudi and Hitzman, 1986).

Skajit carbonate rocks in the southern Brooks Range contain a few fossils, mainly of Devonian age, but rocks mapped as the skajit Limestone locally contain fossils as old as Middle Ordovician (Nelson and Grybeck, 1980; Tom Dutro, written commun., 1987). The thickness and distribution of the skajit along the $600 \mathrm{~km}$ length of the southern Brooks Range suggest that it formed a regionally extensive but relatively narrow carbonate platform. Tectonic and erosional remnants of at least partly coeval and biostratigraphically similar carbonate platforms are represented in east-central Alaska by the Porcupine platform of the Coleen area, the Tatonduk sequence of the Charley River area, and the Nixon Fork platform (Blodgett, 1983) in southwestern Alaska. The Cassiar platform (Tempelman-Kluit, 
1977) in southern Yukon Territory is analogous. Biostratigraphic similarities demonstrate the close paleogeographic ties among most of these terranes, and with the North American miogeocline (Blodgett, 1983; Savage and others, 1985).

Furthermore, some much thinner Lower to Middle Devonian carbonate and calcareous shale horizons containing similar faunas occur within more heterogeneous, clastic to volcanic-bearing, probably rift-controlled assemblages of east-central Alaska, suggesting that the platform carbonates may have interfingered with the rift assemblages (Brosgè and others, 1979). The best examples are the Cascaden Ridge unit and the Schwatka sequence of the Livengood area, and the Woodchopper Volcanics of the Charley River area (Lane and Ormiston, 1976; Blodgett, 1987).

The Mississippian Kekiktuk Conglomerate lies in regional unconformity on Devonian and older rocks. The unconformity is profoundly angular in some places, and a discontinuity elsewhere, suggesting an environment of localized Devonian and Mississippian tectonism comparable to that interpreted for the Earn Group in central Yukon Territory (Gordey and others, 1982, 1987). The Kekiktuk and the Kayak Shale are included within the Endicott Group, which is mapped within the northern Yukon extension of the the Cordilleran fold-and-thrust belt.

Skeletal, micritic, and cherty limestone and dolomite of Lisburne age and character continue southeastward into the northern Yukon segment of the Cordilleran fold-and-thrust belt, where they are mapped as the Hart River and Ettrain Formations (Norris, 1984). Correlation of the Lisburne Group with the Hart River and Ettrain Formations would imply that late Paleozoic depositional environments were similar if not continuous between the eastern Brooks Range and the northern Cordilleran miogeocline. Subtle unconformities within the Lisburne have been related by Schoennagel (1977) to unconformities recording Antler orogenic pulses in the western United States.

Permian clastic lithologies of the Siksikpuk Formation and Sadlerochit Group resemble those of the Step Conglomerate and Tahkandit Limestone of the Charley River area, and the Jungle Creek Formation of northern Yukon Territory (Norris, 1984). The Triassic Shublik Formation is similar in lithology, age, and petroleum source bed potential to the lower part of the Glenn shale in the Charley River region (D. Morgridge, oral commun., 1987).

Origin of the Tozitna terrane. Mississippian to Triassic (or Jurassic) argillite, chert, and other sedimentary rocks in the Tozitna terrane of silberling and Jones (1984) differ both in their basinal character and in their association with voluminous mafic igneous rocks from most of the coeval sequences in adjacent terranes of east-central Alaska (fig. 20). Two fundamentally different interpretations have been proposed for the origin of the Tozitna terrane.

One interpretation is that the Tozitna originated as oceanic crust beyond the North American depositional margin, and was then transported and obducted onto its present substrate (Churkin and others, 1982; Patton and others, 1977; Coney, 1983; Coney and Jones, 1985). Opinions differ as to the direction of transport and the location of the root zone. Patton and others (1977) suggest that the terrane originated in the Koyukuk basin (fig. 20) and was transported southeastward from a root zone now represented by the dismembered Kanuti ophiolite. Coney (1983) and Coney and Jones (1985) suggest an origin from south of the Yukon-Tanana upland 
(fig. 20) involving generally northward transport. In either case, this accretionary model requires hundreds of kilometers of semi-coherent unidirectional tectonic transport of a relatively thin and regionally extensive sheet across continental crust.

The other interpretation is that the Tozitna terrane originated locally as a parautochthonous intracratonic rift assemblage in which oceanic crust was generated (Gemuts and others, 1983). In this parautochthonous rift interpretation, collapse of the rift sequence and facies-telescoping at its margins during subsequent Mesozoic convergence produced ductilely sheared, bedding-controlled detachments and conventional fold-and-thrust belt structures that require much smaller distances of transport than does the accretionary model.

Geophysical data for the Tozitna terrane discussed by Cady (1987) are not diagnostic for either of these models, and paleomagnetic evidence bearing on the origin and amount of tectonic transport of the Tozitna terrane is sparse and inconclusive because of alteration, regional reheating, and complex structural relations.

The Tozitna problem is not a provincial one unique to east-central Alaska, but is interregional in scope. Rock sequences similar in lithic content, range of age, and deformational character to the Tozitna terrane are recognized the length of the Cordilleran orogen from Alaska to Nevada. Those sequences in east-central Alaska and the northern Canadian Cordillera for which accretionary origins have previously been suggested are the seventymile (Foster and others, in press); the Sylvester, Nina Creek, and Slide Mountain (Monger, 1977); and the Anvil allochthons (Tempelman-Kluit, 1979 and 1984; Gordey, 1981). The equivalence of these sequences emphasizes the vast extent and continuity on an interregional scale of the transported sheet that would be required by any model of obductive accretion, and compounds the mechanical difficulty of transporting more or less coherently so extensive a sheet across hundreds of kilometers of continental crust.

Aside from the mechanical problem presented by such large-scale obduction, the geologic framework of east-central Alaska, as summarized in this report, best supports the collapsed intracratonic rift model to explain the origin of the Tozitna terrane. Evidence leading to this interpretation is:

(1) The interregional occurrence of Tozitna rocks no older than Early Mississippian to latest Devonian on a substrate no younger than Late Devonian. Although the rocks of the Tozitna terrane and its substrate are typically imbricated with one another near their contact, the interregional extent and consistency of the stratigraphic stacking order of the Tozitna and its substrate is difficult to reconcile with any model of far-traveled accretion, and argues strongly for an originally depositional contact between the two (see Monger and Ross, 1979).

(2) Inconsistencies in the direction of tectonic transport indicated by shear fabrics in mylonites at the base of the Tozitna terrane that are difficult to reconcile with unidirectional allochthonous transport of the magnitude required (Miyaoka and Dover, in press). Preliminary fabric studies in the Ray Mountains 
and southern Tanana quadrangle suggest movement generally upward and outward over crystalline terranes lying outboard from the Tozitna terrane (fig.20).

(3) Local stratigraphic ties between the Tozitna terrane and adjacent or underlying rock sequences. Possible stratigraphic interfingering is present in the Christian River sequence of the Coleen area, in the Yukon-Tozitna Rivers part of the Ray Mountains area, and in the western Charley River area. The interfingering is analogous to that already proposed between platform and riftcontrolled sequences of the outer Cordilleran miogeocline that were active intermittently from Late Proterozoic through Paleozoic time.

(4) Similarities in mafic igneous associations with other suspected riftsequences in the outer part of the Cordilleran miogeocline. The petrologic similarities of all of these occurrences suggest similar modes of origin. The volcanic rocks of Late Proterozoic to Early Cambrian(?) age in the upper part of the Tindir Group, the Devonian Woodchopper Volcanics, and the Tozitna terrane are lithologically indistinguishable from the Ordovician Fossil Creek Volcanics (Wheeler-Crowder and others, 1987), and from those in the Mount Harper complex (Roots, 1988), whose highly alkalic tholeitic composition suggests an extensional, continental rift origin. The abundance of intrusive rocks in the Tozitna terrane may be a function of the degree of basin opening and tensional spreading (see Struik, 1987). Occurrences of mafic intrusive rocks resembling those of the Tozitna terrane are also mapped locally in adjacent rock sequences within the Ray Mountains, Beaver, and Coleen areas, suggesting that the mafic rocks are not "rootless" within a gigantic Tozitna allochthon, but also penetrated its substrate near the Tozitna basin margins (see Monger and Price, 1979).

(5) The possible North American affinity of faunas. The paleogeographic affinities of radiolarians and the sparse conodont and shelly faunas characterizing the Tozitna terrane are not well known. However, in the northern Canadian Cordillera, terranes analogous to the Tozitna in lithic content and geologic setting contain a fusulinid assemblage comparable to that in the southwestern United States (Monger and Ross, 1971; Struik, 1981). This suggests fragmentation and dispersion of North American rocks by major strike-slip, but not an origin external to North America.

In combination, these factors lead me to the conclusion that the Tozitna terrane does not require a far-traveled, exotic, accretionary origin. On the contrary, the interregional continuity, consistency, and relative simplicity of the paleogeographic and paleotectonic framework inherent in the intracratonic rift model supports the conclusion that the Tozitna terrane represents the culmination of an extensional rift- or basin-forming process that operated intermittently from Proterozoic to early Mesozoic time within the outer part of the Cordilleran miogeocline. Struik (1987) reached the same conclusion for the equivalent terranes of the northern Canadian Cordillera.

I conclude that all the terranes of east-central Alaska, including the Tozitna terrane, are fragments of North American continental crust and intracontinental basins that were telescoped and dispersed by classical nonaccretionary processes. Plate convergence is inferred to have been concentrated at the outboard edge of the Brooks Range-Ruby-Yukon/Tanana crystalline belt (fig. 
20), which most likely represents the outer limit of North American continental crust, and the inboard limit of terrane accretion.

Mesozoic flysch sequence. The Lower Cretaceous Kandik Group, Upper Jurassic and Lower Cretaceous Wilbur Creek unit, and upper part of the Glenn Shale in the southern part of the east-central Alaska region, and laterally equivalent rocks preserved locally in central Yukon Territory, all form part of a foreland depositional basin that can be traced continuously through northern Yukon Territory (fig. 20) to the Blow trough north of the Brooks Range (Dixon, 1986; Young, 1973). The basin evolved from a shallow epicontinental marine basin to a deeper flysch trough. The continuity of the foreland basin and the similarity of its detritus on an interregional scale seem to preclude the possibility of diverse origins for local segments of the flysch sequence. The flysch was derived primarily from uplifted, orogenically active source areas containing mainly crystalline rocks and variably metamorphosed distal deposits of the Paleozoic Cordilleran miogeocline. The source areas were located outboard of the epicontinental basin, in what are now the hinterland portions of the northern Cordilleran and Brooks Range fold-and-thrust belts, and in the southern Brooks Range, Ruby, Yukon-Tanana, and Yukon crystalline terranes.

\section{Crystalline terranes of interior Alaska--continental arc origin}

The similarities in protoliths, structural and metamorphic histories, and granitic plutonism that lead to the correlation of the crystalline terranes of interior Alaska with one another, together with their regional distribution and relations to major tectonic features, suggest that all these terranes originally comprised a more continuous crystalline belt that was tectonically segmented into the southern Brooks Range, Ruby, and Yukon-Tanana crustal blocks (fig. 20). The crystalline belt is here interpreted to be a continental or Andean-type arc that formed along the outermost part of the Cordilleran miogeocline (Burchfiel and others, 1987). The arc underwent crustally contaminated granitic plutonism in mid-Paleozoic time (Dusel-Bacon and Aleinikoff, 1985), possibly generated in an ancestral continental arc- or aborted arc-forming event (Smith and Rubin, 1987). However, the mid-Paleozoic effects are largely masked by far more intense and widespread tectonic, metamorphic, and igneous arc-forming processes resulting from plate convergence in Jurassic to mid-Cretaceous time.

The stratigraphic framework on which the proposed Mesozoic arc was built included: (1) quartz-rich, continentally derived gritty sediments of Late Proterozoic and Early Cambrian age similar to those of the Windermere Supergroup in Yukon Territory, through which older Precambrian blocks interpreted to be rifted fragments of the North American craton are locally preserved; (2) dominantly argillaceous distal deposits of the intermittently extending early and middle Paleozoic Cordilleran miogeocline, in which mafic intrusive materials and diverse sedimentary facies as well as some regionally important carbonate platform deposits had rift-controlled distributions; (3) quartz- and chert-rich conglomerates and related clastic deposits, with locally interfingering mafic igneous and carbonate buildups, derived mainly from locally active block uplifts during Devonian and Early Mississippian time; and (4) upper Paleozoic and lower Mesozoic rocks of the Tozitna terrane. As interpreted here, the Tozitna terrane 
developed mainly in a broad and regionally subsiding basin inboard of the axis of later Mesozoic arc development (fig. 20), but Tozitna deposition may have overlapped the future site of the arc, as well, possibly in smaller faultcontrolled basins like those influencing earlier deposition. The position of the main Tozitna basin inboard from the axis of the Devonian and Mississippian arc also suggests an origin as an intracontinental backarc basin (see Monger and Price, 1979).

A Canadian counterpart of the Alaska segment of the continental arc is the Yukon crystalline terrane of southern Yukon Territory, for which a displaced North American origin is suspected (Mortensen and Jilson, 1985; LeCouteur and TempelmanKluit, 1976; Gabrielse, 1985).

\section{Distribution and significance of fold-and-thrust belts}

Recognition of the Charley River fold-and-thrust belt, and of a displaced segment of it in the Livengood area, provides a critical link in Alaska between the fold-and-thrust belts of the northern Canadian Cordillera and the eastern Brooks Range (fig. 20). This regionally continuous belt, as represented on numerous regional geologic and tectonic maps (King, 1969; Norris, 1984), forms the Alaskan arm of the bifurcated foreland fold-and-thrust belt described by Norris (1987). The most prominent aspect of the belt is its z-shaped configuration, consisting of a broad salient in northern Yukon Territory (called the old Crow salient on fig. 20) and a much tighter recess in the Charley River area (called the Charley River recess on figure 20). Equally striking is the systematic change in direction of tectonic transport around the "bends" of the fold-and-thrust belt so as to maintain a consistent "inboard" or forelandward direction of transport, toward the North American craton, or in the case of the Brooks Range, toward an inferred former position of the craton (fig. 20).

In east-central Alaska, dateable fold-and-thrust belt deformation is bracketed between the Albian age of the youngest rocks involved and the Maestrichtian(?) age of the oldest unconformably overlapping rocks, and is therefore restricted to a relatively short span of about $20 \mathrm{~m} . \mathrm{y}$. in the midCretaceous. If earlier compression occurred, its deformational effects cannot be identified from data currently available. However, flysch deposits of the Upper part of the Glenn Shale and the Kandik Group, and their correlatives along the length of the fold-and-thrust belt, record uplift presumably associated with orogenesis in the more outboard or hinterland crystalline parts of the orogen in Jurassic and Early Cretaceous time. Farther east, toward the foreland, the Upper Cretaceous Eagle plain Formation is involved in minor thrusting and broad folding, indicating that contractional deformation there is either younger or lasted longer than in the Charley River fold-and-thrust belt. Moreover, major folds of the Eagle plain Formation are truncated by high-angle faults that bound the southern part of the old Crow salient of the fold-and-thrust belt ( $\mathrm{fig} .20$ ). If, as map patterns suggest, these faults merge with fold-and-thrust belt structures within the salient (Norris, 1984), then at least some thrust faults within that part of the salient must have had post-Late Cretaceous movement. 
Jurassic to Lower Cretaceous foredeep deposits record the earlier pulses of uplift and orogeny in the Brooks Range, but major thrusting (Brookian) in the central Brooks Range also occurred in the mid-Cretaceous (Tailleur and Brosgè, 1970). Progressively younger thrusting occurred northward toward the foothills and the Arctic slope, where Tertiary thrusting predominates and compressive stresses remain active today (Kelley and Foland, 1987; Grantz and others, 1987). In the southeastern Brooks Range, several bundles of imbricate thrust faults appear to merge to the southeast with lineaments splaying northeastward from the Kobuk-Malamute fault zone (fig. 20), suggesting that the thrust bundles are structures on which the predominantly right-slip motion of the lineaments is accommodated by imbricate thrusting. If, as map patterns suggest, the major strike-slip movement on the Kobuk-Malamute system post-dates the main pulse of mid-Cretaceous Brookian thrusting, then concurrent movement on the imbricate thrust bundles of the southeastern Brooks Range would be of comparable late- to post-Brookian age.

Besides strengthening the structural link between the northern Cordilleran and Brooks Range orogens, recognition of the classical fold-and-thrust belt framework of much of the east-central Alaska region demonstrates a far greater degree of disruption of already complex stratigraphic patterns by typical foldand-thrust belt processes than was previously suspected. Telescoping on conventional fold-and-thrust belt structures of small to moderate displacement provides a reasonable explanation for the juxtaposition of apparently disparate rock facies and sequences in east-central Alaska.

\section{Major strike-slip fault systems--pattern, timing, significance, and restoration of offset}

The two principal strike-slip fault systems of the east-central Alaska region are the Tintina and Kobuk-Malamute systems (fig. 20). The continuity of the Tintina fault zone with its two main splays, the Kaltag-Victoria Creek and Tozitna faults, and the case for right-lateral separation in Alaska comparable to the 450 $\mathrm{km}$ recognized in central Yukon Territory, were discussed in the summary of the Livengood area.

There is no general agreement on the amount, timing, or even the existence of significant right-slip on the Kobuk-Malamute fault zone (Grantz, 1966). However, it follows a major aeromagnetic lineament (Cady, 1978) and is considered here to have produced at least 50 to $75 \mathrm{~km}$ of apparent right-separation of the Tozitna terrane and underlying rock sequences in the Beaver area. It cuts Upper Cretaceous conglomerate (Patton and Miller, 1973) derived from post-Brookian uplift of the Ruby-Hodzana upland and the Brooks Range, and appears to laterally displace the east contact of the mid-Cretaceous Hodzana pluton (Brosgè and others, 1973). The possible genetic relation between the Kobuk-Malamute fault zone and imbricate thrust bundles in the eastern Brooks Range is based on the interpretation of prominent topographic lineaments and high-angle faults mapped discontinuously on published maps as predominently right-slip splays of the KobukMalamute system. 
Other presumably fracture- or fault-controlled lineaments of the east-central Alaska region may also have a significant strike-slip component, judging from the extent of their linear or curvilinear topographic expression. Lineaments with lengths of $150 \mathrm{~km}$ or more cross the Ruby geanticline and the Koyukuk basin margin (figs. 12 and 20). Though poorly documented and not systematically studied, these features locally coincide with mapped high-angle faults and the contacts of some large east-west-trending granitic plutons of mid-Cretaceous age.

Northeast-trending high-angle faults of comparable length are mapped in northern Yukon Territory near the south margin of the old crow salient of the northern Cordilleran fold-and-thrust belt (fig. 20). A major component of rightlateral strike-slip has been inferred for these faults by Norris (1972a), but where they are inferred to cross the old Crow salient and to cut and disrupt foldand-thrust belt structures, none of them, including the "Kaltag" fault (Norris, 1984), displaces fold-and-thrust belt structures laterally to any significant degree. After crossing the old Crow salient of the Cordilleran fold-and-thrust belt, some of the northeast-trending faults swing northward and merge with northsouth-trending extensional faults (Norris, 1984) and(or) thrust faults (Lane, 1988) of the Rapid depression. The limited and discontinuous extent of exposure in the critical area of structural intersection, combined with the sinuosity of some faults within the northeast-trending system, also seem to allow for the interpretation that at least some of the northeast-trending faults merge with fold-and-thrust belt structures of the old Crow salient. If so, these could be additional examples of right-lateral slip transformed into thrusting within the old Crow salient, like that inferred for the eastern Brooks Range.

The northeast-trending faults of northern Yukon Territory do not significantly displace middle to late Mesozoic stratigraphic and structural belts of the old Crow salient, and available data indicate that they do not mark any fundamental pre-Cretaceous stratigraphic boundaries. Although they may have influenced pre-Cretaceous deposition to some extent, examples of apparent stratigraphic continuity across the zone of northeast-trending faults were summarized above for the Coleen area and northern Yukon Territory. These indicate at least intermittent stratigraphic continuity across this zone of faults. Furthermore, there is no geological, geophysical, or physiographic evidence to suggest that any of the northeast-trending faults in northern Yukon Territory is a major through-going feature connected across the Yukons Flat basin with the strike-slip faults of the Livengood or Ray Mountains areas (fig. 20). A connection between the "Kaltag" fault of northern Yukon Territory (Norris, 1984; Norris and Yorath, 1981, p.85-7) and the Kaltag fault of west-central Alaska (Patton and Hoare, 1968) is denied not only by its lack of expression in the Coleen area and by the lack of supporting evidence across the intervening Yukon Flats basin, but also by the mapped connection between the kaltag fault and the Tintina fault system in the Livengood area. The "Kaltag" fault of Yukon Territory appears to be of no more individual importance than several other faults within the southern part of the old Crow salient. Based on all the foregoing local and regional map interpretations, no major, through-going "Porcupine lineament" (Churkin and Trexler, 1980, 1981), "Kaltag" megashear, or other fundamental discontinuity required by various megatectonic models (for example, see Nilson, 1981, and Jones, 1982) is recognized in east-central Alaska. 
Paleogeographic and paleotectonic reconstruction of the complex stratigraphic and structural framework of east-central Alaska first requires the restoration of movement on the major strike-slip fault systems. All of the strike-slip motion documented or interpreted on these systems in east-central Alaska is rightlateral. Restoration of the $450 \mathrm{~km}$ of right-separation inferred for the Tintina fault system in the Livengood, Charley River, and Dawson areas is illustrated in figure 10. Motion on the Kobuk-Malamute system and its possible splays in the old Crow salient is more conjectural, but a maximum of about $100 \mathrm{~km}$ of rightseparation seems reasonable and is arbitrarily used here for palinspastic restoration. The restoration shown in figure 21 for the east-central Alaska region and some adjacent areas is discussed by Dover (1985b).

The areal disposition of major dextral strike-slip fault systems with respect to the two "bends" in the $\mathrm{z}$-shaped configuration of the northern CordilleranBrooks Range fold-and-thrust belt suggests a genetic relation between the two-possibly a relation in map view analogous to duplex formation above a structural ramp in cross-section (fig. 22). However, the palinspastic restoration illustrated in figure 21 shows that the Cordilleran-Brooks Range fold-and-thrust belt had a subdued but still pronounced z-shaped configuration prior to strikeslip motion on the Tintina and Kobuk-Malamute fault systems. Therefore, although strike-slip attenuated and accentuated the "bends," it did not cause them.

Coincidence of the Tintina fault system along much of its length with the northwest trend of fault-controlled facies belts in the outer part of the Late Proterozoic and Paleozoic northern Cordilleran miogeocline suggests that the Tintina trend may have been controlled by Paleozoic and older crustal rifting. The suggestion that the Tintina fault zone reactivates a Mesozoic suture zone (Churkin and others, 1982) is not supported by current interpretations based on the most recent mapping.

\section{oroclinal bending and crustal rotation}

The z-shaped pattern of stratigraphic and structural trends in east-centrtal Alaska has significant implications for paleotectonic and paleographic reconstruction. The $\mathrm{z}$-shape is defined not only by the Cordilleran-Brooks Range fold-and-thrust belt, but also by all the major stratigraphic belts of eastcentral Alaska (fig. 20), including (1) the crystalline terranes, (2) Proterozoic and Paleozoic chert- and mafic volcanic-bearing outer miogeoclinal sequences, carbonate platform sequences, (4) the Devonian and Mississippian metaclastic sequence, (5) the Tozitna terrane, and (6) Jurassic to Lower Cretaceous flysch (fig. 21). This pattern is consistent for a strip of mainly continental crust with a minimum width of $250 \mathrm{~km}$ and a strike length of at least $2000 \mathrm{~km}$. The fact that the change of nearly 100 degrees in tectonic trend around the Charley River recess coincides with a comparable change in the direction of thrust transport, led Dover (1985a, and in press) to suggest that the recess might represent an oroclinal bend. If so, the means by which space is accomodated within the oroclinal core is not clear. Interpretation of the old Crow salient as a second, complimentary orocline is inherent in the models of Canada basin opening and Brooks Range rotation proposed by Carey (1958), Tailleur and Brosgè (1970), Tailleur (1972), and Grantz and others (1982), and Milazzo and others (1987). The 


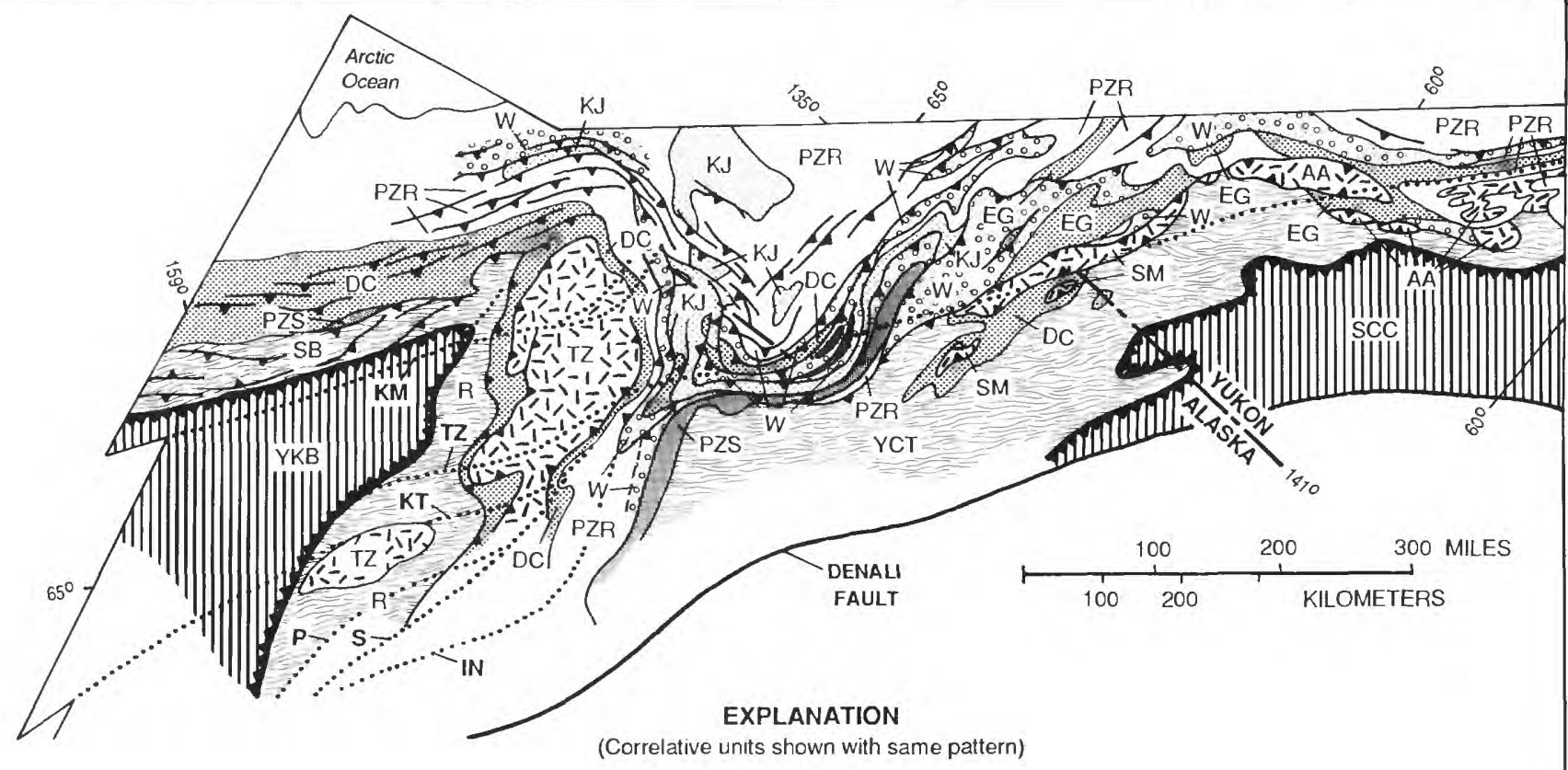

ROCKS OF NORTH AMERICA AND INTRACONTINENTAL RIFT BASINS

$\mathrm{KJ}$-Cretaceous and Jurassic foreland basin deposits

Lower Mesozoic to upper Paleozoic mafic volcanic and intrusive rocks, chert, and clastic rocks

AA--Anvil allochthons of Tempelman-Kluit (1979)

SM--Seventy Mile terrane of Silberling and Jones (1987)

TZ--Tozitna terrane of Silberling and Jones (1987) Mississippian and(or) Devonian clastic rocks DC--Devonian clastic rocks of this report EG--Earn Group of Gordey and others (1982) PZR--Paleozoic rocks, mainly carbonate facies PZS--Paleozoic rocks, mainly shaly facies W--Cambrian and Upper Proterozoic Wickersham grit unit and rocks of Windermere Group, undivided
NORTH AMERICAN CONTINENTAL ARC ROCKS
ACCRETED OCEANIC OR VOLCANIC ARC ROCKS

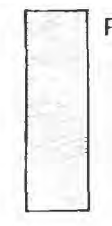

Paleozoic and Upper Proterozoic metamorphic rocks

R--Ruby terrane of Silberling and Jones (1987)

SB--South flank schist belt

YCT--Yukon crystalline terrane of Churkin and others (1982)

Contac: Thrust fault or sheared unconformity --Sawteeth on upper plate

Major accretionary boundary--Sawteeth on accreted block

-- Alaska-Yukon boundary

Figure 21. Pre-Tintina geologic configuration. Restoration removes 40 degrees of post-Tintina counter-clockwise bending of the Tintina fault system, and $425 \mathrm{~km}$ of cumulative right-slip from the Tintina fault system. Restoration of Tintina fault movement based on removal of slip from constituent splays, including $130 \mathrm{~km}$ from the Kaltag fault (KT), $20 \mathrm{~km}$ from unnamed faults inferred to cross yukon Flats basin, $75 \mathrm{~km}$ from the Tozitna fault (TZ), $125 \mathrm{~km}$ on the Susulitna (S) and Poorman (P) faults, combined, and $75 \mathrm{~km}$ on the Iditarod-Nixon Fork fault (IN). Also, $100 \mathrm{~km}$ removed from the Kobuk-Malamute fault (KM) . 


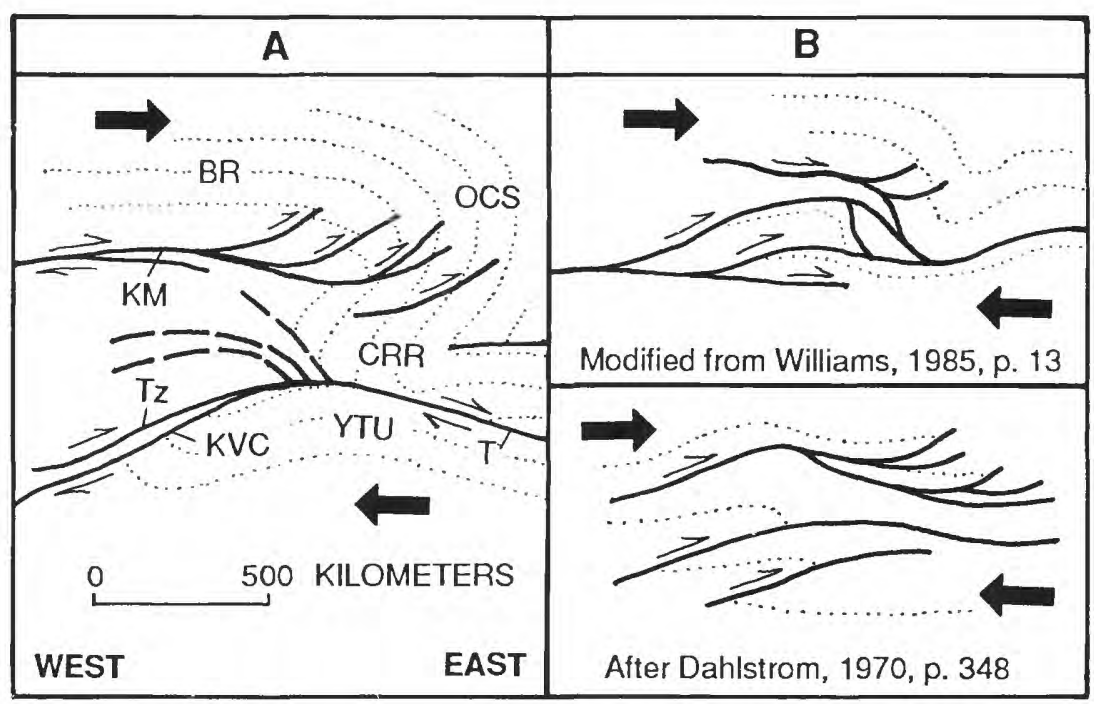

Figure 22. Comparison of fault patterns in map and cross-section views. A, Generalized strike-slip fault pattern of east-central Alaska in map view. B, Examples of thrust fault patterns in crosssection view. Explanation of symbols: BR, Brooks Range; OCS, Old Crow salient; KM, Kobuk-Malamute fault; CRR, Charley River recess; Tz, Tozitna fault; KVC, Kaltag-Victoria Creek fault; T, Tintina fault; YTU, Yukon-Tanana upland. 
model of Norris (1972b) relating paired en-echelon belts of oppositely verging structures to continental margin irregularities does not explain the fundamental $\mathrm{z}$-shaped pattern considered here.

If the displacement history postulated here for the Tintina fault system is valid, then the abrupt 40 degree bend in the Tintina system in the Livengood area must have occurred after most of the strike-slip was completed. Otherwise, transpression would have been required on the part of the system now trending to the southwest. Counterclockwise bending of the Tintina system and its splays in southwest Alaska is tentatively attributed by Dover (1985b) to a major Tertiary crustal rotation event now being documented in west-central Alaska (Coe and others, 1985; Thrupp and Coe, 1986; Coe and Thrupp, 1987).

\section{Extensional origin of Yukon Flats basin}

The position of the Yukon Flats basin (Kirschner, in press, a) between the Tintina and Kobuk-Malamute strike-slip systems suggests that it could have originated as a pull-apart basin in a region of secondary tension generated by dextral shear between the Tintina and Kobuk-Malamute fault systems (fig. 23A). Intermittent Tertiary and Quaternary movement accompanied by synorogenic deposition and local mafic volcanism, and continuing extension which maintains the low topography of the basin, would require that at least one of the bounding strike-slip systems is still active. Alternatively, because the Yukon Flats basin is on the convex side of the bend in the Tintina fault system, as are other extensional basins in south-central Alaska relative to bends in the Denali and Border Ranges fault systems (fig. 23B), all of these basins may be caused by tension induced by the Tertiary crustal rotation event, and localized within strike-slip-bounded crustal layers at the apices of the bends. If so, crustal rotation must still be active.

\section{PALEOGEOGRAPHIC AND GEOTECTONIC MODEL}

The paleogeographic and geotectonic model presented here is offered as a testable alternative to accretionary tectonic models implied in the tectonostratigraphic terrane subdivision of east-central and Arctic Alaska, and also as an alternative to geotectonic models requiring thousands of kilometers of lateral movement on megashears passing through east-central Alaska. The model that best fits the geologic framework of east-central Alaska, as presently understood and summarized in this chapter (fig. 24), incorporates (1) a passive and intermittently extending Late Proterozoic to Triassic depositional prism that wrapped continuously from the Cordilleran miogeocline into the Innuitian miogeocline (Franklinian and Ellesmerian sequences) of the Canadian Arctic islands, along the ancient North American margin; (2) two periods of continental arc development generated by plate convergence along the outer edge of this margin, with possible back-arc spreading associated with the first, and a major fold-and-thrust belt developed during the second; (3) the bifurcating fold-andthrust belt model of Norris (1987); and (4) concepts of rotational Canada basin 


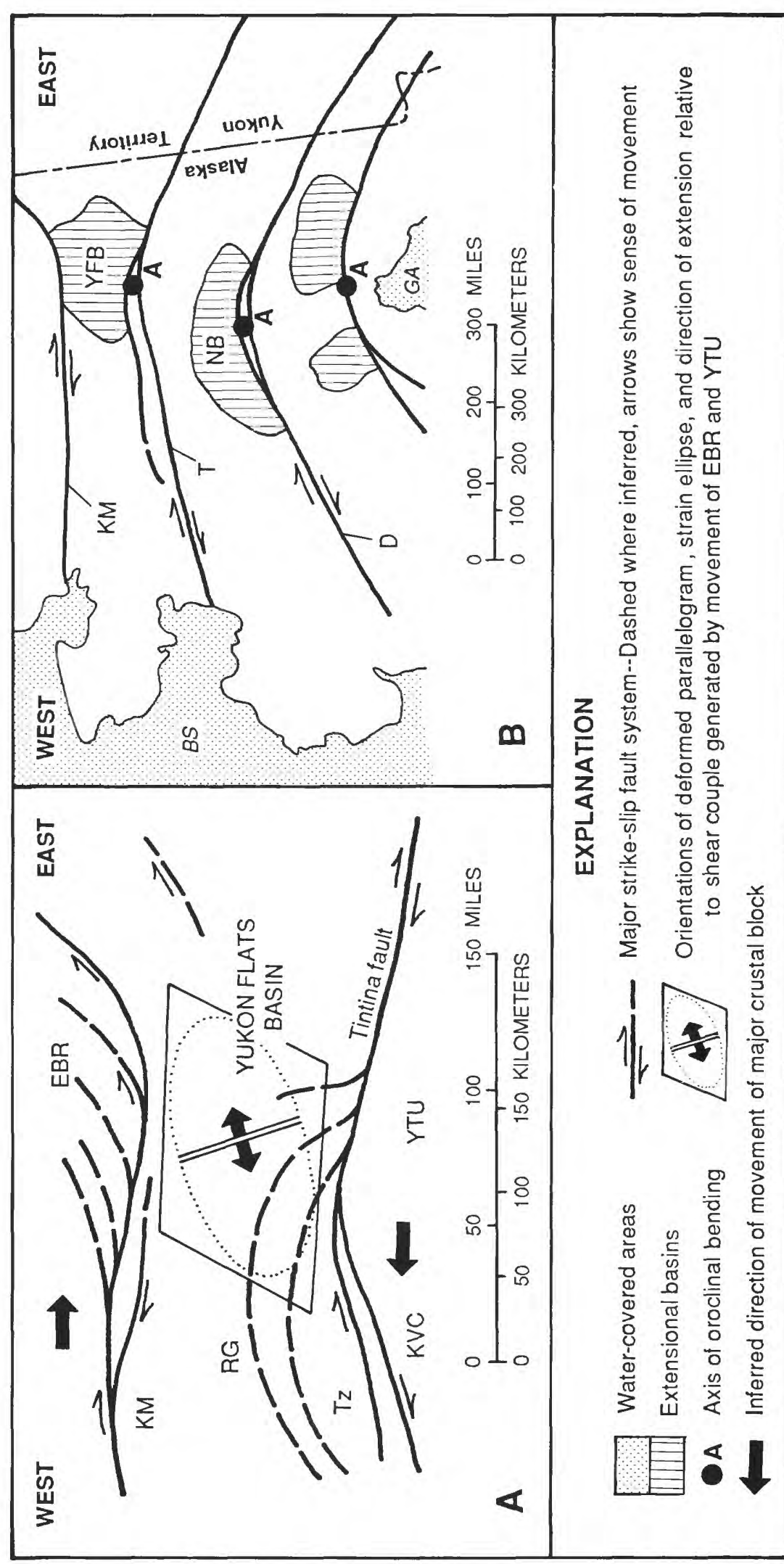

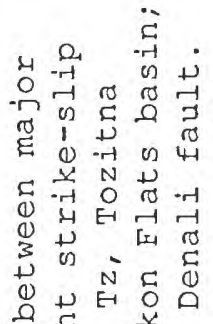

द

- $\rightarrow$ E

पत्न ल

+0 व

मी

حِ 0 O

E मु

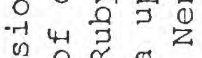

(1) 0 至

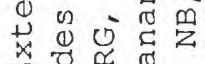

प्र व

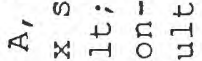

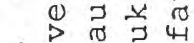

- 党先

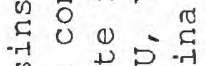

尓

ह

당 न

है थ 1 ह

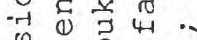

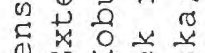

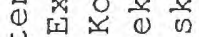

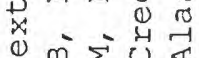

H.

ص

ᄃ

न

- $\lambda_{1}>$

莒 की

1) +000

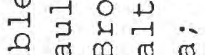

ने

记品 ن

म $\begin{array}{ll}\text { D } \\ \text { e }\end{array}$

ले 0 i

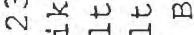

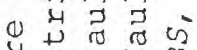

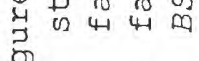

on
-1
-1 


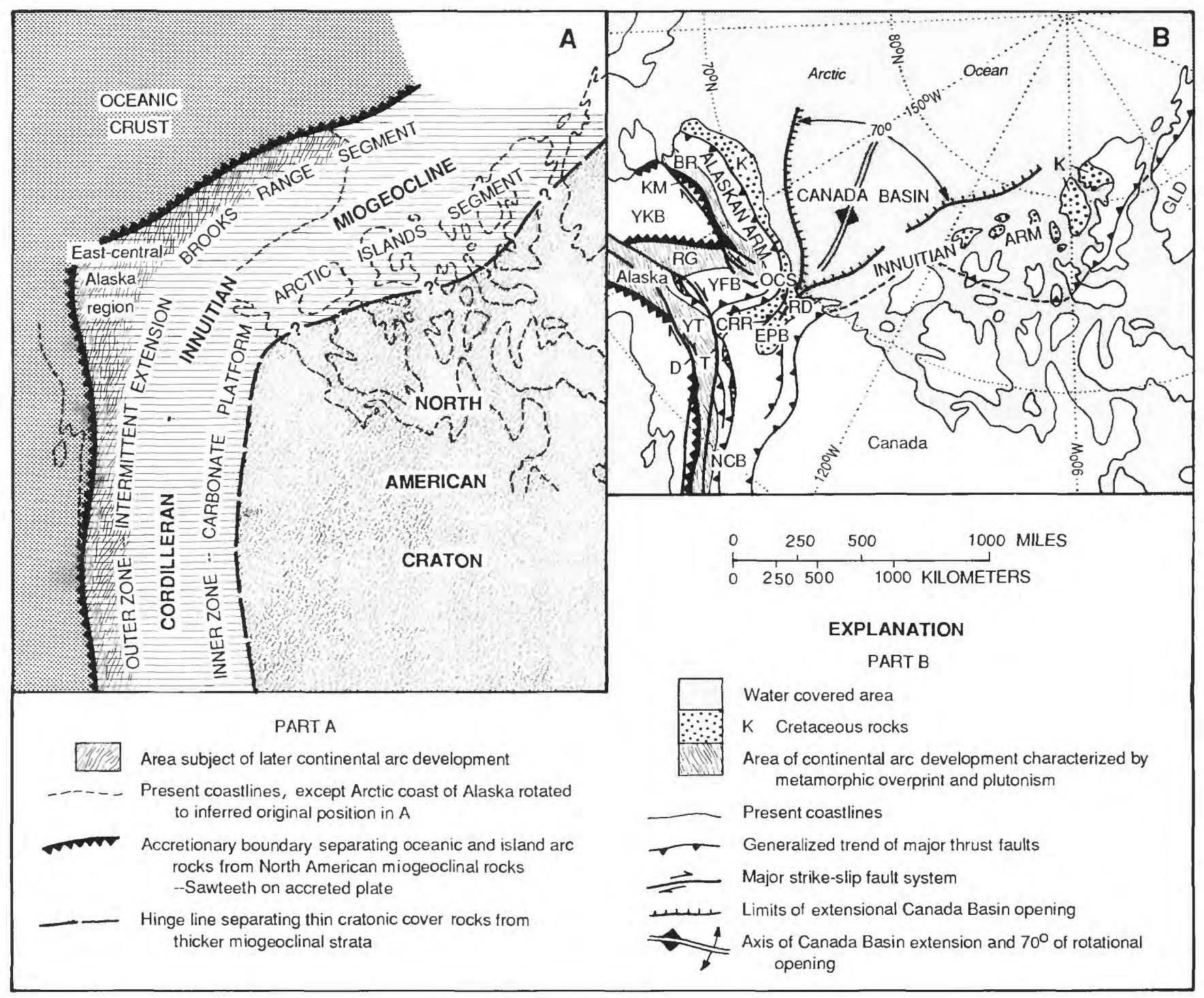

Figure 24. Regional geotectonic model. A, Inferred configuration of Cordilleran-Innuitan miogeocline prior to Canada basin opening. B, Present tectonic configuration, after Canada basin opening and associated oroclinal bending, and major strike-slip faulting (also, see Norris, 1987). GLD, Greenland; AK, Alaska; KM, Kobuk-Malamute fault; BR, Brooks Range; YKB, Yukon-Koyukuk basin; YFB, Yukon Flats basin; RD, Rapid depression; OCS, Old Crow salient; CRR, Charley River recess; EPB, Eagle Plain basin; YT, Yukon-Tanana upland; D, Denali fault; T, Tintina fault; RG, Ruby geanticline; NCB, Northern Cordilleran fold-and-thrust belt. 
opening held by Carey (1958), Tailleur and Brosgè (1970), Tailleur (1972), Freeland and Dietz (1973), and Grantz and others (1982), and recently supported by paleomagnetic evidence from Arctic Alaska (Halgedfahl and Jarrard, 1987). In this model, the "bends" in the $\mathrm{z}$-pattern of stratigraphic and structural trends have two different origins (fig. 24):

(1) The Charley River recess reflects an original swing in the trend of the ancient North American margin from predominantly northwest-southeast in the Canadian Cordillera to northeast-southwest in the Innuitian belt of Arctic Canada (represented by Norris's Innuitian arm of the bifurcated Cordilleran fold-andthrust belt). The miogeoclinal prism flanking this originally curved continental margin had an intermittent history of extension from Proterozoic through early Mesozoic time, interrupted in the Devonian and Early Mississippian by an incipient continental arc-forming event that produced uplift and granitic plutonism along its outer edge but little documented metamorphism or contractional deformation. Rift basins within the miogeoclinal prism contain siliceous and siliciclastic rocks, and mafic igneous material; coarse clastic rocks were derived from accompanying block uplifts. Carbonate rocks like those of the Mackenzie, Cassiar, Nixon Fork, Porcupine, and skajit platforms rimmed the basins, including the early Paleozoic Selwyn basin and Richardson trough, or capped intervening block uplifts. More advanced extension of the late Paleozoic to Triassic Tozitna basin, accompanied by regional subsidence, produced the most mafic-rich of the extensional basins. The Tozitna is regarded as an aborted ocean-forming rift that may have originated as an intra-cratonic back-arc basin inboard of the aborted mid-Paleozoic continental arc. Beginning with metamorphism and plutonism in Jurassic time and continuing with major supracrustal fold-and-thrust belt development in the mid-Cretaceous, a full-fledged continental arc generated by plate convergence was superimposed along the outer edge of the North American miogeocline over the site of the aborted mid-Paleozoic one, and a foreland flysch basin developed along the length of the orogen. The outboard edge of the crystalline terranes of east-central Alaska which formed the continental arc is considered to be the inboard limit of accretionary terranes in Alaska.

(2) The Old Crow Salient, represented by Norris's Alaskan arm of the foldand-thrust belt, is a true Cordilleran-Brooks Range orocline produced by rotation of Arctic Alaska from the Canadian Arctic islands during opening of the Canada basin (fig. 24). The Rapid depression and probably the Eagle plain depression to the south, which together separate the unrotated Innuitian and rotated Alaskan arms of the bifurcated Cordilleran fold-and-thrust belt, would be on-land intracratonic rift-basins representing the apex of Canada basin opening. Some rotation of Arctic Alaska may have been coeval with compressional development of the Cordilleran-Brooks Range fold-and-thrust belt.

The opposing "bends" of the $\mathrm{z}$-pattern were later attenuated by dextral strikeslip fault systems, possibly reflecting a change in plate motions at about $80 \mathrm{Ma}$ along the Alaskan segment of the North American continental margin from direct to more oblique convergence. Alternatively, the period of major strike-slip may have coincided with east-west compression generated by convergence between North America and Eurasia. 


\section{ACKNOWLEDGMENTS}

Many colleagues contributed expertise as consultants, critics, or editors that significantly improved this presentation of the geology of east-central Alaska. The principal contributors and their main areas of interest are: Michael Churkin--stratigraphy of the Charley River area; Thomas Dutro--Paleozoic stratigraphy of Porcupine platform and southeastern Brooks Range; Florence Weber-geology of the Circle/Livengood area; John Cady--geophysics of east-central Alaska; Robert Chapman--geology of the Livengood/Tanana area; Steven Gordey-geology of southern Yukon Territory and the mid-Paleozoic Earn Group; and Bob Thompson--geology of the Dawson area. However, the author accepts full responsibility for the interpretations and conclusions presented here, which may not necessarily represent the views of the contributors.

\section{REFERENCES CITED}

Arth, J.G., 1985, Neodymium and strontium isotopic composition of Cretaceous plutons of the Yukon-Koyukuk basin, Ruby geanticline, and Seward Peninsula, Alaska [Abs.]: Eos (American Geopysical Union Transactions) v. 66, p. 1102.

Albanese, M.D., 1983, Bedrock geologic map of the Livengood B-4 quadrangle, Alaska: Alaska Division of Geological and Geophysical Surveys Report of Investigations $83-3$, scale $1: 40,000$.

Bamber, E.W., and waterhouse, J.B., 1971, Carboniferous and Permian stratigraphy and paleontology, northern Yukon Territory, Canada: Bulletin of Canadian Petroleum Geology v.19, no. 1, p. 29-250.

Barker, J.C., 1986, Placer gold deposits of the Eagle trough, upper Yukon River region, Alaska: Bureau of Mines Information Circular 9123, 20 p.

Blodgett, R.B., 1983, Paleobiogeographic affinities of Devonian fossils from the Nixon Fork terrane, southwestern Alaska, in Stevens, C.H., ed., Pre-Jurassic rocks in western North American suspect terranes: Society of Economic Paleontologists and Mineralogists, p. 125-130.

----1987, Taxonomy and paleobiogeographic affinities of an early Middle Devonian (Eifelian) gastropod faunule from the Livengood quadrangle, east-central Alaska [Unpublished Ph.D. thesis]: Oregon State University (Corvallis, Oregon).

Blodgett, R.B., Wheeler-Crowder, K.L., Rohr, D.M., Harris, A.G., and Weber, F.R., 1987, Late Ordovician fossils from the Fossil Creek volcanics of the Livengood quadrangle--significance for Late Ordovician glacio-eustasy: U.S. Geological Survey Circular 998, p. 54-58. 
Blodgett, R.B., zhang, Ning, Ormiston, A.R., and Weber, F.R., 1988, A Late Silurian age determination for the limestone of the "Lost Creek unit,", Livengood C-4 quadrangle, east-central Alaska: U.S. Geological Survey Circular 1016, p. 56-58.

Brabb, E.E., 1967, Stratigraphy of the Cambrian and ordovician rocks of eastcentral Alaska: U.S. Geological Survey Professional Paper 559-A, 30 p.

----1969, Six new Paleozoic and Mesozoic formations in east-central Alaska: U.S. Geological Survey Bulletin 1274-I, $26 \mathrm{p}$.

----1970, Preliminary geologic map of the Black River quadrangle, east-central Alaska: U.S. Geological Survey Miscellaneous Geologic Investigations Map I601 , scale $1: 250,000$.

Brabb, E.E., and Churkin, Michael, Jr., 1967, Stratigraphic evidence of the Late Devonian age of the Nation River formation, east-central Alaska, in Geological Survey research 1967: U.S. Geological Survey Professional Paper 575-D, P. D4-D15.

---1969, Geologic map of the Charley River quadrangle, east-central Alaska: U.S. Geological Survey Miscellaneous Geologic Investigations Map I-573, scale $1: 250,000$.

Brooks, A.H., and Kindle, E.M., 1908, Paleozoic and associated rocks of the upper Yukon, Alaska: Geological Society of America Bulletin, vol. 19, p. 255-314.

Brosgè, W.P., 1960, Metasedimentary rocks in the south-central Brooks Range, Alaska: U.S. Geological Survey Professional Paper 400-B, p. B351-B352.

---1975, Metamorphic belts in the southern Brooks Range: U.S. Geological Survey Circular 722, p. 40 .

Brosgè, W.P., and Dutro, J.T., Jr., 1973, Paleozoic rocks of northern and central Alaska: American Association of Petroleum Geologists Memoir 19, p. 361-375.

Brosgè, W.P., Dutro, J.T., Jr., Mangus, M.D., and Reiser, H.N., 1962, Paleozoic sequence in eastern Brooks Range, Alaska: American Association of Petroleum Geologists Bulletin, v. 46, no. 12, p. 2174-2198.

Brosgè, W.P., Lanphere, M.A., Reiser, H.N., and Chapman, R.M., 1969, Probable Permian age of the Rampart Group, central Alaska: U.S. Geological Survey Bulletin 1294-B, 18 p.

Brosgè, W.P., and Reiser, H.N., 1962, Preliminary geologic map of the Christian quadrangle, Alaska: U.S. Geological Survey Open-File Map 62-15, scale $1: 250,000$. 
---1964, Geologic map and section of the Chandalar quadrangle, Alaska: U.S. Geological Survey Miscellaneous Geologic Investigations Map I-375, scale $1: 250,000$.

---1965, Preliminary geologic map of the Arctic quadrangle, Alaska: U.S. Geological Survey Open-File Report 65-22, scale $1: 250,000$.

---1969, Preliminary geologic map of the Coleen quadrangle, Alaska: U.S. Geological Survey Open-File Map 69-25, scale 1:250,000.

Brosgè, W.P., Reiser, H.N., and Dutro, J.T., Jr., 1979, Significance of Middle Devonian clastic rocks in the eastern Brooks Range, Alaska: U.S. Geological Survey Circular 823-B, p. B24-B25.

Brosgè, W.P., Reiser, H.N., Dutro, J.T., Jr., and Churkin, Michael, Jr., 1966, Geologic map and stratigraphic sections, Porcupine River Canyon, Alaska: U.S. Geological Survey Open-File Report 66-10, 4 sheets, scale 1:63,360.

Brosgè, W.P., Reiser, H.N., Dutro, J.T., Jr., and Detterman, R.L., 1976: Reconnaissance geologic map of the Table Mountain quadrangle, Alaska, U.S. Geological Survey Open-File Map 76-546.

Brosgè, W.P., Reiser, H.N., and Yeend, Warren, 1973, Reconnaissance geologic map of the Beaver quadrangle, Alaska: U.S. Geological Survey Miscellaneous Field Studies Map MF-525, scale 1:250,000.

Burchfiel, B.C., Eaton, G.P., Lipman, P.W., and Smith, R.B., 1987, The Cordilleran orogen: Conterminous U.S. sector, in Palmer, A.R., ed., Perspectives in regional geological synthesis: Geological Society of America DNAG Special Publication 1, p. 91-98.

Burns, L.E., Newberry, R.J., and Reifenstuhl, R.R.,1987, Intrusive rocks of the Lime Peak-Mt. Prindle area, in Smith, T.E., Pessell, G.H., and Wiltse, 1987, Mineral assessment of the Lime Peak-Mt. Prindle area, Alaska: Alaska Division of Geological and Geophysical Surveys, p. 3-1 to 3-78.

Cady, J.W., 1978, Aeromagnetic map and interpretation, Chandalar quadrangle, Alaska: U.S. Geological Survey Miscellaneous Field Studies Map MF-878C, scale $1: 250,000$.

---1986, Geophysics of the Yukon-Koyukuk province: U.S. Geological Survey Circular 978, p. 21-25.

----1987, Preliminary geophysical interpretation of the oceanic terranes of interior and western Alaska--evidence of thick crust of intermediate density: American Geophysical Union Geodynamic Series v. 19, p. 301-305.

Cady, J.W., and Morin, R.L., Aeromagnetic and gravity data, in Weber, F.R., McCammon, R.B., Rinehart, C.D., and Light, T.D., Mineral resources of the White Mountain National Recreation Area, east-central Alaska: U.S. Geological Survey Open-File Report 88-284, p 55. 
Cady, J.W., and Weber, F.R., 1983, Aeromagnetic map and interpretation of magnetic and gravity data, Circle quadrangle, Alaska: U.S. Geological Survey OpenFile Report 83-170C, 29 p., scale 1:250,000.

Cairnes, D.D., 1914, The Yukon-Alaska international boundary, between Porcupine and Yukon Rivers: Geological Survey of Canada Memoir 67, $161 \mathrm{p}$.

Carey, S.W., 1958, A tectonic approach to continental drift, in Carey, S.W., ed., Continental drift, a symposium: Tasmania University, p. 177-355.

Cecile, M.P., 1982, The lower Paleozoic Misty Creek embayment, Selwyn Basin, Yukon and Northwest Territories, with a paleontologic index by W.H. Fritz, B.S. Norford and R.S. Tipnis: Geological Survey of Canada Bulletin 335, 78 p., 1 map, scale $1 ; 500,000$.

Chapman, R.M., 1974, Metamorphic rock sequence between Rampart and Tanana dated: U.S. Geological Survey Circular 700, p. 42.

Chapman, R.M., Trexler, J.H., Jr., Churkin, Michael, Jr., and Weber, F.R., 1985, New concepts of the Mesozoic flysch belt in east-central Alaska: U.S. Geological Survey Circular 945, p. 29-32.

Chapman, R.M., Weber, F.R., Churkin, Michael, Jr., and Carter, Claire, 1979, The Livengood Dome chert, a new Ordovician formation in central Alaska, and its relevance to displacement on the Tintina fault: U.S. Geological Survey Professional Paper 1126-F, P. F1-F13.

Chapman, R.M., Weber, F.R., and Taber, Bond, 1971, Preliminary geologic map of the Livengood quadrangle, Alaska: U.S. Geological Survey Open-File Report 7166 , scale $1: 250,000$.

Chapman, R.M., Yeend, Warren, Brosgè, W.P., and Reiser, H.N., 1982, Reconnaissance geologic map of the Tanana quadrangle, Alaska: U.S. Geological Survey OpenFile Report $82-734,20$ p., scale $1: 250,000$.

Chipp, E.R., 1970, Geology and Geochemistry of the Chandalar area, Brooks Range, Alaska: Alaska Department of Natural Resources, Division of Mines and Geology, Geologic Report no. 42, $39 \mathrm{p}$.

Churkin, Michael, Jr., and Brabb, E.E., 1965a, Ordovician, Silurian, and Devonian biostratigraphy of east-central Alaska: American Association of Petroleum Geologists Bulletin, v. 49, no. 2, p. 172-185.

----1965b, Occurrence and stratigraphic significance of Oldhamia, a Cambrian trace fossil, in east-central Alaska: U.S. Geological Survey Professional Paper 525-D, P. D120-D124.

---1968, Devonian rocks of the Yukon-Porcupine Rivers area and their tectonic relation to other Devonian sequences in Alaska, in Proceedings of the International Symposium on the Devonian System, vol. 2: Alberta Society of Petroleum Geologists (Calgary, Alberta), p. 227-258. 
Churkin, Michael, Jr., and Carter, Claire, 1970, Devonian tentaculitids of eastcentral Alaska; systematics and biostratigraphic significance: Journal of Paleontology, v. 44, no. 1, p. 51-68.

Churkin, Michael, Jr., Foster, H.L., Chapman, R.M., and Weber, F.R., 1982, Terranes and suture zones in east-central Alaska: Journal of Geophysical Research, v. 87, no. B5, p. 3718-3730.

Churkin, Michael, Jr., and Trexler, J.H., 1980, Circum-Arctic plate accretion-isolating part of a Pacific plate to form the nucleus of the Arctic basin: Earth Platetary Science Letters v. 48, p. 356-362.

----1981, Continental plates and accreted oceanic terranes in the Arctic, in Nairn, A.E., Churkin, Michael, Jr., and Stehli, F.G., eds., The ocean basins and margins, volume 5: The Arctic ocean: Plenum Press, New York, p. 1-20.

Clough, J.G., 1980, Fossil alage in Lower Devonian limestones, east-central Alaska, in Short notes on Alaskan geology, 1979-80: Alaska Division of Geological and Geophysical Surveys Geologic Report 63, p. 19-21.

Clough, J.G., and Blodgett, R.B., 1984, Lower Devonian basin to shelf carbonates in outcrop from the western Ogilvie Mountains, Alaska and Yukon Territory, in Eliuk, L.S., ed., Carbonates in subsurface and outcrop, 1984 Canadian Society of Petroleum Geologists Core Conference Manual: Calgary, Alberta, Canada, Canadian Society of Petroleum Geologists, p. 57-81.

Coe, R.S., Globerman, B.R., Plumley, P.W., and Thrupp, G.A., 1985, Paleomagnetic results from Alaska and their tectonic implications, in Howell, D.G., ed., Tectonostratigraphic terranes of the circum-Pacific region: Circum-Pacific Council for Energy and Mineral Resources, Houston, Texas, p. 85-108.

Coe, R.S., and Thrupp, G.A., 1987, Tectonic implications of rotated paleo-magnetic declinations in west-central Alaska: Geological Society of America Abstracts with Programs v. 19, no. 6, p. 367.

Coleman, D.A., 1985, Shelf to basin transition of Silurian-Devonian rocks, Porcupine River area, east-central Alaska: American Association of Petroleum Geologists Bulletin, v. 69, no. 4, p. 659.

Coney, P.J., 1983, Structural and tectonic aspects of accretion in Alaska, in Howell, D.G., Jones, D.I., Cox, Allan, and Nur, Amos, Proceedings of the circum-Pacific terrane conference: Stanford University Publications, p. 6870 .

Coney, P.J., and Jones, D.L., 1985, Accretion tectonics and crustal structure in Alaska: Tectonophysics v. 119, p. 265-283.

Coney, P.J., Jones, D.L., and Monger, J.W.H., 1980, Cordilleran suspect terranes: Nature, v. 288, p. 329-333. 
Cushing, G.W., 1984, Early Mesozoic tectonic history of the eastern Yukon-Tanana upland [Unpublished Masters thesis]: State University of New York (Albany, New York).

Cushing, G.W., and Foster, H.L., 1984, Structural observations in the Circle quadrangle, Yukon-Tanana upland, Alaska: U.S. Geological Survey Circular 868 , p. $64-65$.

Cushing, G.W., Foster, H.L., Laird, J., and Burack, A.C., 1982, Description and preliminary interpretation of folds and faults in a small area in the Circle B-4 and B-5 quadrangles, Alaska: U.S. Geological Survey Circular 844, p. 56-58.

Cushing, G.W., Meisling, K.E., Christopher, R.A., and Carr, T.R., 1986, The Cretaceous to Tertiary evolution of the Tintina fault zone, east-central Alaska: Geological Society of America Abstracts with Programs v. 18, no. 2, p. 98 .

Dahlstrom, C.D.A., 1970, Structural geology in the eastern margin of the Canadian Rocky Mountains: Bulletin of Canadian Petroleum Geology, v. 18, no. 3, p. 332-406.

Davies, W.E., 1972, The Tintina trench and its reflection in the structure of the Circle area, Yukon-Tanana upland, Alaska: Twenty-fourth International Geological Congress, Section 3--Tectonics (Montreal, Canada), p. 211-216.

Delaney, G.D., 1981, The mid-Proterozoic Wernecke Supergroup, Wernecke Mountains, Yukon Territory, in Campbell, F.H.A., ed., Proterozoic basins of Canada: Geological Survey of Canada Paper 81-10, p. 1-23.

Dillon, J.T., Brosgè, W.P., and Dutro, J.T., 1986, Generalized geologic map of the Wiseman quadrangle, Alaska: U.S. Geological Survey Open-File Report 86-219, scale $1: 250,000$.

Dillon, J.T., Patton, W.W., Jr., Mukasa, S.B., Tilton, G.R., Blum, J., and Moll, E.R., 1985, New radiometric evidence for the age and thermal history of the metamorphic rocks of the Ruby and Nixon Fork terranes, west-central Alaska: U.S. Geological Survey Circular 945, p. 13-18.

Dillon, J.T., Pessel, G.H., Chen, J.H., and Veach, N.C., 1979, Tectonic and economic significance of Late Devonian and Late Proterozoic U-Pb zircon ages from the Brooks Range, Alaska: Alaska Division of Geology and Geophysical Surveys Geologic Report, no. 61, p. 36-4.

----1980, Middle Paleozoic magmatism and orogenesis in the Brooks Range, Alaska: Geology, v. 8, p. 338-343.

Dixon, J., 1986, Comments on the stratigraphy, sedimentology and distribution of the Albian Sharp Mountain Formation, northern Yukon, in Current research, Part B: Geological Survey of Canada Paper 86-1B, p. 375-381. 
Dover, J.H., 1985a, Possible oroclinal bend in northern Cordilleran fold and thrust belt, east-central Alaska: Geological Society of America, Abstracts with Programs v. 17 , no. 6, p. 352.

----1985b, Dispersion of Tintina fault displacement in interior Alaska: Geological Society of America, Abstracts with Programs v. 17, no. 6, p. 352 .

----1988, Geologic cross sections, in Weber, F.R., McCammon, R.B., Rinehart, C.D., Light, T.D., and Wheeler, K.L., Geology and mineral resources of the White Mountains National Recreation Area, east-central Alaska: U.S. Geological Survey Open-file Report 88-284, Plate II-B.

----in press, Geologic map and fold-and-thrust-belt interpretation of the southeastern part of the Charley River quadrangle, east-central Alaska: U.S. Geological Survey Miscellaneous Investigations Map I-1942, scale $1: 100,000$.

Dover, J.H., and Miyaoka, R.T., 1985a, Major rock packages of the Ray Mountains, Tanana and Bettles quadrangles: U.S. Geological Survey Circular 945, p. 3236 .

----1985b, Metamorphic rocks of the Ray Mountains; preliminary structural analysis and regional tectonic implications: U.S. Geological Survey Circular 945, p. 36-38.

1985c, Metamorphic rocks and structure of the Ray Mountains, southeast borderland of Koyukuk basin, Alaska: Eos (American Geophysical Union Transactions) v. 66, no. 46, p. 1101-1102.

---1988, Reinterpreted geologic map and fossil data, Charley River quadrangle, east-central Alaska: U.S. Geological Survey Miscellaneous Field Studies Map MF-2004, scale $1: 250,000$.

Dusel-Bacon, Cynthia, and Aleinikoff, J.N., 1985, Petrology and tectonic significance of augen gneiss from a belt of Mississippian granitoids in the Yukon-Tanana terrane, east-central Alaska: Geological Society of America Bulletin, v. 96 , p. 411-425.

Dusel-Bacon, Cynthia, and Foster, H.L., 1983, A sillimanite gneiss dome in the Yukon crystalline terrane, east-central Alaska: Petrography and garnetbiotite geothermometry: U.S. Geological Survey Professional Paper 1170-E, p. E1-E25.

Dutro, J.T., Jr., 1979, Alaska, in The Mississippian and Pennsylvanian (Carboniferous) systems in the United States: U.S. Geological Survey Professional Paper 1110 M-DD, p. DD1-DD16.

Dutro, J.T., Jr., Brosgè, W.P., and Reiser, H.N., 1977, Upper Devonian depositional history, central Brooks Range, Alaska: U.S. Geological Survey Circular 751-B, p. B16-B18. 
Dutro, J.T., Jr., and Harris, A.G., 1987, Some stratigraphic and paleontologic constraints on tectonic modelling of the Brooks Range, Alaska: Geological Society of America Abstracts with Programs v.19, no. 6, p. 374.

Dutro, J.T., Jr., and Jones, D.L., 1984, Paleotectonic setting of the Carboniferous of Alaska: International Congress on Carboniferous stratigraphy and geology, v. 9, no. 3, p. 229-234.

Eakin, H.M., 1916, The Yukon-Koyukuk region, Alaska: U.S. Geological Survey Bulletin $631,88 \mathrm{p}$.

Eberlein, D.E., and Lanphere, M.A., in press, Precambrian rocks of Alaska--a review, in Harrison, J.E., and Peterman, Z.E., eds., Introduction to the correlation of Precambrian rock sequences: U.S. Geological Survey Professional Paper 1241B.

Einaudi, M.T., and Hitzman, M.W., 1986, Mineral deposits in northern Alaska: Introduction: Economic Geology and the Bulletin of the Society of Economic Geologists v. 81, no. 7, p. 1583-1591.

Foster, H.L., Cushing, G.W., Weber, F.R., Laird, J., Jones, D.L., Murchey, B.L., and Blome, C.D., 1982, Radiolaria indicate Carboniferous and Triassic ages for chert in the Circle Volcanics, Circle quadrangle: U.S. Geological Survey Professional Paper, p. 78.

Foster, H.L., Keith, T.E.C., and Menzie, W.D., 1987, Geology of east-central Alaska: U.S. Geological Survey Open-File Report 87-188, 59 p.

this volume, Geology of the Yukon-Tanana area of east-central Alaska, in Plafker, G., Jones, D.L., and Berg, H.C., eds., Geology of Alaska: Geological Society of America (Boulder, Colorado), The Geology of North America.

Foster, H.L., Laird, J., Keith, T.E.C., Cushing, G.W., and Menzie, W.D., 1983, Preliminary geologic map of the Circle quadrangle, Alaska: U.S. Geological Survey Open-File Report 83-170A, 32 p., 1 map, scale 1:250,000.

Foster, R.L., 1968, Potential for lode deposits in the Livengood gold placer district, east-central Alaska: U.S. Geological Survey Circular 590, 18 p.

----1969, Nickeliferous serpentinite near Beaver Creek, east-central Alaska: U.S. Geological Survey Circular 615, p. 2-4.

Freeland, G.L., and Dietz, R.S., 1973, Rotation history of Alaskan tectonic belts: Tectonophysics v. 18, p. 379-389.

Gabrielse, Hubert, 1985, Major dextral transcurrent displacements along the northern Rocky Mountain Trench and related lineaments in north-central British Columbia: Geological Society of America Bulletin v. 96, no. 1, p. $1-14$. 
Gabrielse, H., and Yorath, C.J., 1987, The Cordilleran orogen: Canadian sector, in Palmer, A.J., ed., Perspectives in regional geological synthesis: Geological Society of America DNAG Special Publication 1, p. 81-89.

Gardner, M.C., Jarrard, R.D., and Mount, V., 1984, Style and origin of structures, Paleozoic and Precambrian sedimentary rocks of southern Tatonduk Terrane, Alaska: Geological Society of America Abstracts with Programs v. 16, no. 5, p. 285 .

Gemuts, I., Puchner, C.C., and Steffel, C.I., 1983, Regional geology and tectonic history of western Alaska: Journal of the Alaska Geological Society v. 3, p. 67-85.

Gordey, S.P., 1981, Stratigraphy, structure, and tectonic evolution of southern Pelly Mountains in the Indigo Lake area, Yukon Territory: Geological Survey of Canada Bulletin 318, $44 \mathrm{p} ., 1$ map, scale 1:60,000.

Gordey, S.P., Abbott, J.G., and Orchard, M.J., 1982, Devono-Mississippian (Earn Group) and younger strata in east-central Yukon, in Current Research, Part B: Geological Survey of Canada Paper 82-1B, p. 93-100.

Gordey, S.P., Abbott, J.G., Tempelman-Kluit, D.J., and Gabrielse, Hubert, 1987, "Antler" clastics in the Canadian cordillera: Geology, v. 15, p. 103-107.

Gottschalk, R.R., 1987, Tectonics of the schist belt metamorphic terrane near Wiseman, Alaska: Geological Society of America Abstracts with Programs v.19, no. 6, p. 383 .

Grantz, Arthur, 1966, Strike-slip faults in Alaska: U.S. Geological Survey OpenFile Report 66-53, $82 \mathrm{p}$.

Grantz, Authur, Dinter, D.A., and Culotta, R.C., 1987, Structure of the continental shelf north of the Arctic National Wildlife Refuge, in Bird, K.J., and Magoon, L.B., eds., Petroleum geology of the northern part of the Arctic National Wildlife Refuge, northeastern Alaska: U.S. Geological Survey Bulletin 1778, p. 271-276.

Grantz, Arthur, Johnson, Leonard, Sweeney, J.F., Clark, D.L., Edholm, Olav, Falconer, R.K.H., Hopkins, D.M., Kristoffersen, Yngve, Larsen, H.C., and Thiede, Jorn, 1982, The Arctic region, in Palmer, A.R., ed., Perspectives in regional geological synthesis: planning for the geology of North America: Geological Society of America DNAG Special Publication 1, p. 105-115.

Green, L.H., 1972, Geology of Nash Creek, Larsen Creek, and Dawson map-areas, Yukon Territory: Geological Survey of Canada Memoir 364, 157 p., 3 maps, scale $1: 250,000$.

Grybeck, Donald, and Nelson, S.W., 1981, Structure of the Survey Pass quadrangle, Brooks Range, Alaska: U.S. Geological Survey Miscellaneous Field Studies Map MF-1176-B, 7 p., 1 map, scale $1: 250,000$. 
Halgedahl, S.L., and Jarrard, R.D., 1987, Paleomagnetism of the Kuparuk River Formation from oriented drill core: evidence for rotation of the Arctic Alaska plate, in Tailleur, I., and Weimer, P., eds., Alaskan North Slope geology: Society of Economic Paleontologists and Mineralogists (Pacific Section) and Alaska Geological Society, p. 581-617.

Herreid, Gordon, 1969, Geology and geochemistry Sithylemenkat Lake area, Bettles quadrangle, Alaska: Alaska Department of Natural Resources, Division of Mines and Geology, Geologic Report no. 35, 22 p.

Hitzman, M.W., Proffett, J.M., Jr., Schmidt, J.M., and Smith, T.E., 1986, Geology and mineralization of the Ambler district, north-western Alaska: Economic Geology, v. 81, p. 1592-1618.

Hitzman, M.W., Smith, T.E., and Proffett, J.M., Jr., 1982, Bedrock geology of the Ambler district, southwestern Brooks Range, Alaska: Alaska Division of Geological and Geophysical Surveys Geologic Report 75, scale 1:125,000.

Holdsworth, Brian, and Jones, D.L., 1979, Late Paleozoic fossils in ophiolite, northeastern Alaska: U.S. Geological Survey Professional Paper 1150, p. 95.

Howell, D.G., Murray, R.W., Wiley, T.J., Boundy-Sanders, Susan, and KauffmanLinam, Linden, 1987, Sedimentology and tectonics of the Devonian Nation River formation, Alaska, part of yet another allocthonous terrane: American Association of Petroleum Geologists Abstracts with Programs v.71, no. 5, p. 569 .

Hughes, J.D., and Long, D.G.F., 1979, Geology and coal resource potential of Early Tertiary strata along Tintina trench, Yukon Territory: Geological survey of Canada Paper 79-32, 21 p.

Jones, D.L., Bounday-Sanders, Susan, Murray, R.L., Howell, D.G., and Wiley, T.J., 1987, Tectonic contacts of miogeoclinal strata in east-central Alaska: American Association of Petroleum Geologists Abstracts with Programs v. 71, no. 5, p. 573 .

Jones, D.L., Howell, D.G., Coney, P.J., and Monger, J.W.H., 1983, Recognition, character, and analysis of tectono-stratigraphic terranes in western North America, in Hashimoto, M., and Uyeda, S., eds., Accretion tectonics in the Circum-Pacific regions: Terra Scientific Publishing Company (Tokyo), p. 2135 .

Jones, D.L., Silberling, N.J., Berg, H.C., and Plafker, George, 1981, Tectonostratigraphic terrane map of Alaska: U.S. Geological Survey OpenFile Report 81-792, scale 1:250,000.

Jones, D.L., Silberling, N.J., Chapman, R.M., and Coney, Peter, 1984, New ages of radiolarian chert from the Rampart district, east-central Alaska: U.S. Geological Survey Circular 868, p. 39-43. 
Jones, D.L., Silberling, N.J., Coney, P.J., and Plafker, George, 1987, Lithotectonic terrane map of Alaska (west of the 141st Meridian): U.S. Geological Survey Miscellaneous Field Studies Map MF-1874A one sheet, scale $1: 2,500,000$.

Jones, P.B., 1982, Mesozoic rifting in the western Arctic ocean basin and its relationship to Pacific seafloor spreading, in Embry, A.F., and Balkwill, H.R., eds., Arctic Geology and Geophysics--Proceedings of the Third International Symposium on Arctic Geology: Canadian Society of Petroleum Geologists Memoir 8, p. 83-99.

Karl, Susan, and Long, C.I., 1987, Evidence for tectonic truncation of regional east-west trending structures in the central Baird Mountains quadrangle, western Brooks Range, Alaska: Geological Society of America Abstracts with Programs v. 19, no. 6, p. 392 .

Kelley, J.S., and Foland, R.L., 1987, Structural style and framework geology of the coastal plain and adjacent Brooks Range, in Bird, K.J., and Magoon, L.B., eds., Petroleum geology of the northern part of the Arctic National Wildlife Refuge, northeastern Alaska: U.S. Geological Survey Bulletin 1778, p. $255-270$.

Kindle, E.M., 1908, Geologic reconnaissance of the Porcupine Valley, Alaska: Geological Society of America Bulletin 19, p. 315-338.

King, P.B., compiler, 1969, Tectonic map of North America: U.S. Geological Survey Map, scale 1:5,000,000.

Kirschner, C.E., this volume, Interior basins of Alaska, in Plafker, G., Jones, D.L., and Berg, H.C., eds., Geology of Alaska: Geological Society of America (Boulder, Colorado), The Geology of North America.

Laird, Jo, and Foster, H.L., 1984, Description and interpretation of a mylonitic foliated quartzite unit and feldspathic quartz wacke (grit) unit in the Circle quadrangle, Alaska: U.S. Geological Survey Circular 939, p. 29-33.

Lane, L.S., 1988, The Rapid fault array: a foldbelt in Arctic Yukon, in Current Research, Part D: Geological Survey of Canada Paper 88-1D, p. 95-98.

Lane, H.R., and Ormiston, A.R., 1976, The age of the Woodchopper Limestone (Lower Devonian), Alaska: Geologica et Palaeontologica v. 10, p. 101-108.

----1979, Siluro-Devonian biostratigraphy of the Salmontrout River area, eastcentral Alaska: Geologica et Pelaeontologica v. 13, p. 39-96.

Laudon, L.R., Hartwig, A.E., Morgridge, D.L., Omernik, J.B., 1966, Middle and Late Paleozoic stratigraphy, Alaska-Yukon border area between Yukon and Porcupine Rivers: American Association of Petroleum Geologists Bulletin, v. 50, no. 9, p. $1868-1889$. 
LeCouteur, P.C., and Tempelman-Kluit, D.J., 1976, Rb/Sr ages and a profile of initial $\mathrm{Sr}^{87} / \mathrm{Sr}^{86}$ ratios for plutonic rocks across the Yukon crystalline terrane: Canadian Journal of Earth Sciences v. 13, p. 319-30.

Loney, R.A., and Himmelberg, G.R., 1985a, Distribution and character of the peridotite-layered gabbro complex of the southeastern Yukon-Koyukuk ophiolite belt: U.S. Geological Survey Circular 945, p. 46-48.

----1985b, Ophiolitic ultramafic rocks of the Jade Mountains-Cosmos Hills area, southwestern Brooks Range: U.S. Geological Survey Circular 967, p. 13-15.

Long, C.C., and Miyakoa, R., 1988, Resistivity cross-section, in Weber, F.R., McCammon, R.B., Rinehart, C.D., and Light, T.D., in press, Mineral resources of the White Mountain National Recreation Area, east-central Alaska: U.S. Geological Survey Open File Report 88-284, p 73-76.

Maddren, A.G., 1913, The Koyukuk-Chandalar region, Alaska: U.S. Geological Survey Bulletin 532, $119 \mathrm{p}$.

Maddren, A.G., and Harrington, G.L., 1955, Geologic maps of the area along the Alaska-Canada boundary between the Porcupine River and Arctic Ocean: U.S. Geological Survey Open-File Report 55-105.

Mertie, J.B., 1925, Geology and gold placers of the Chandalar district, Alaska: U.S. Geological Survey Bulletin 773-E, p. 215-263.

----1929, The Chandalar-Sheenjek district Alaska: U.S. Geological Survey Bulletin 810-B, p. 87-139.

----1930, Geology of the Eagle-Circle district, Alaska: U.S. Geological Survey Bulletin $816,168 \mathrm{p}$.

1932, The Tatonduk-Nation district, Alaska: U.S. Geological Survey Bulletin 836-E, $109 \mathrm{p}$.

----1937, The Yukon-Tanana region, Alaska: U.S. Geological Survey Bulletin 872, $276 \mathrm{p}$.

Miller, T.P., 1985, Petrologic character of the plutonic rocks of the YukonKoyukuk basin and its borderland (abs.): Eos (American Geophysical Union Transactions) v. 66 , no. 46, p. 1102 .

Miller, T.P., this volume, Pre-Cenozoic plutons of Alaska, in Plafker, G., Jones, D.I., and Berg, H.C., eds., Geology of Alaska: Geological Society of America (Boulder, Colorado), The Geology of North America, .

Milazzo, Giulio, Plumley, P.W., and Whalen, M.T., 1987, Tertiary tectonics of the Porcupine terrane, NE Alaska: Eos (American Geophysical Union) v.68, no. 16, p.292. 
Miyaoka, R.T., and Dover, J.H., 1985, Preliminary study of shear sense in mylonites, eastern Ray Mountains, Tanana quadrangle: U.S. Geological Survey Circular 967, p. 29-32.

-----in press, Shear sense in mylonites, and implications for transport of the Rampart assemblage (Tozitna terrane), Tanana quadrangle, east-central Alaska, in Dover, J.H., and Galloway, J.P., eds., Geologic studies in Alaska by the U.S. Geological Survey, 1989: U.S. Geological Survey Bulletin.

Monger, J.W.H., 1977, Upper Paleozoic rocks of the western Canadian Cordillera and their bearing on Cordilleran evolution: Canadian Journal of Earth Sciences v. 14 , p. $1832-1859$.

Monger, J.W.H., and Price, R.A., 1979, Geodynamic evolution of the Canadian Cordillera--progress and problems: Canadian Journal of Earth Science v. 16, p. 770-791.

Monger, J.W.H., and Ross, C.A., 1971, Distribution of fusulinaceans in the western Canadian Cordillera: Canadian Journal of Earth Sciences, v. 8, p. 259-278.

----1979, Upper Paleozoic volcanosedimentary assemblages of the western North American Cordillera: Neuvieme Congres International de Stratigraphie et de geologie du Carbonifere v. 3 (Southern Illinois University Press), p. 219228.

Moore, T.E., Wallace, W.K., Karl, S.M., Mull, C.G., Bird, K.J., and Dillon, J.T., this volume, Geology of northern Alaska, in Plafker, G., Jones, D.L., and Berg, H.C., eds., Geology of Alaska: Geological Society of America (Boulder, Colorado), The geology of North America, v.

Mortensen, J.K., and Godwin, C.I., 1982, Volcanogenic massive sulfide deposits associated with highly alkaline rift volcanics in the south-eastern Yukon Territory: Economic Geology and the Bulletin of the Society of Economic Geologists, v. 77, no. 5, p. 1225-1230.

Mortensen, J.K., and Jilson, G.A., 1985, Evolution of the Yukon-Tanana terrane: evidence from southeastern Yukon Territory: Geology v. 13, no. 11, p. 806810 .

Nelson, S.W., and Grybeck, Donald, 1980, Geologic map of the Survey Pass quadrangle, Brooks Range, Alaska: U.S. Geological Survey Miscellaneous Field Studies Map MF-1176A, scale 1:250,000.

Nilsen, T.H., 1981, Upper Devonian and lower Mississippian redbeds, Brooks Range, Alaska, in Miall, A.D., ed., Sedimentation and tectonics in alluvial basins: Geological Association of Canada Special Paper 23, p. 187-219.

Norris, D.K., 1972a, Structural and stratigraphic studies in the tectonic complex of northern Yukon Territory, north of Porcupine River, in Report of Activites, Part B: Geological Survey of Canada Paper 72-1, p. 91-99. 
---1972b, En echelon folding in the northern Cordillera of Canada: Bulletin of Canadian Petroleum Geology v. 20, no. 3, p. 634-642.

----1982, Geology of the Ogilvie River (116G and 116F) map area: Geological Survey of Canada Map 1526A, scale 1:250,000.

----1984, Geology of the northern Yukon and northwestern district of Mackenzie: Geological Survey of Canada Map 1581A, scale 1:500,000.

----1985, The Neruokpuk Formation, Yukon Territory and Alaska, in Current Research, Part B: Geological Survey of Canada Paper 85-1B, p. 223-229.

---1987, Porcupine virgation - a key to the collapse of the Brooks Range orogen: Geological Society of America Abstracts with Programs v. 19, no. 6, p. 437.

Norris, D.K., and Yorath, C.J., 1981, The North American plate from the Arctic Archipelago to the Romanzof Mountains, in Nairn, A.E.M., Churkin, M., Jr., and Stehli, F.G., The ocean basins and margins, Volume 5--The Arctic Ocean: Plenum Press (New York), p. 37-103.

Patton, W.W., Jr., and Box, S.E., 1985, Tectonic setting and history of the YukonKoyukuk basin, Alaska (abs.): Eos (American Geophysical Union Transactions) v. 66 , no. 46, p. 1101 .

Patton, W.W., Jr., and Hoare, J.M., 1968, The Kaltag fault, west-central Alaska: U.S. Geological Survey Professional Paper 600-D, p. D147-D153.

Patton, W.W., Jr., Box, S.E., Moll-Stallcup, E.J., and Miller, T.P., this volume, Geology of west-central Alaska, in Plafker, G., Jones, D.L., and Berg, H.C., eds., Geology of Alaska: Geological Society of America (Boulder, Colorado), The Geology of North America.

Patton, W.W., Jr., and Miller, T.P., 1970, Preliminary geologic investigations in the Kanuti River region, Alaska: U.S. Geological Survey Bulletin 1312-J, 10 p.

----1973, Bedrock geologic map of Bettles and southern part of Wiseman quadrangles, Alaska: U.S. Geological Survey Miscellaneous Field Studies Map MF-492, scale $1: 250,000$.

Patton, W.W., Jr., Miller, T.P., Chapman, R.M., Yeend, Warren, 1978, Geologic map of the Melozitna quadrangle, Alaska: U.S. Geological Survey Miscellaneous Investigations Series Map I-1071, scale 1:250,000.

Patton, W.W., Jr., and Moll, E.J., 1982, Structural and stratigraphic sections along a transect between the Alaska Range and Norton Sound: U.S. Geological Survey Circular 844, p. 76-78.

Patton, W.W., Jr., Stern, T.W., Arth, J.G., and Carlson, Christine, 1987, New U/Pb ages from granite and granite gneiss in the Ruby geanticline and southern Brooks Range, Alaska: Journal of Geology v. 95, p. 118-126. 
Patton, W.W., Jr., Tailleur, I.L., Brosgè, W.P., and Lanphere, M.A., 1977, Preliminary report on the ophiolites of northern and western Alaska, in Coleman, R.G., ed., North American ophiolites: Oregon Department of Geology and Mineral Industries Bulletin no. 95, p. 51-57.

Prindle, L.M., 1905, The gold placers of the Fortymile, Birch Creek, and Fairbanks regions, Alaska: U.S. Geological Survey Bulletin 251, 89 p.

----1906, The Yukon-Tanana region, Alaska; description of Circle quadrangle: U.S. Geological Survey Bulletin 295, 27 p., 1 pl.

----1913, A geologic reconnaissance of the Circle quadrangle, Alaska: U.S. Geological Survey Bulletin 538, 82 p., 2 pls.

Puchner, C.C., 1984, Intrusive geology of the Ray Mountains batholith: Geological Society of America Abstracts with Programs v. 16, p. 329.

Reiser, H.L., Lanphere, M.A., and Brosgè, W.P., 1965, Jurassic age of a mafic igneous complex, Christian quadrangle, Alaska: U.S. Geological Survey Professional paper 525-C, p. C68-C71.

Robinson, M.S., 1983, Bedrock geologic map of the Livengood C-4 quadrangle, Alaska: Alaska Division of Geological and Geophysical Surveys Report of Investigations 83-4, scale $1: 40,000)$.

Roots, C.F., 1983, Mount Harper Complex, Yukon--early Paleozoic volcanism at the margin of the Mackenzie platform, in Current Research, part A: Geological Survey of Canada Paper 83-1A, p. $4 \overline{23}-427$.

----1988, Cambo-Ordovician volcanic rocks in eastern Dawson map-area, Ogilvie Mountains, Yukon, in Yukon geology--annual report of geology section: Department of Indian Affairs and Northern Development, $p$.

Roots, C.F., and Moore, J.M., Jr., 1982, Proterozoic and early Paleozoic volcanism in the Ogilvie Mountains, in Yukon exploration and geology 1982:

Exploration and Geological Services Division, Department of Indian and Northern Affairs, p. 55-62.

Savage, N.M., Blodgett, R.B., and Jaeger, H., 1985, Conodonts and associated graptolites from the late Early Devonian of east-central Alaska and western Yukon Territory: Canadian Journal of Earth Sciences v. 22, no. 12, p. 18801883 .

Schoennagel, F.H., 1977, Mississippian unconformities in northern Alaska related to Antler tectonic pulses: American Association of Petroleum Geologists Bulletin v. 61, no. 3, p. 435-442.

Schrader, F.C., 1900, Preliminary report on a reconnaissance along the Chandalar and Koyukuk Rivers, Alaska, in 1899: U.S. Geological Survey Twenty-first Annual Report, p. 441-486. 
1904, A reconnaissance in Northern Alaska: U.S. Geological Survey Professional Paper 20, 139 p.

Silberling, N.J., and Jones, D.L., eds., 1984, Lithotectonic terrane maps of the North American Cordillera: U.S. Geological Survey Open-File Report 84-523.

Silberling, N.J., Jones, D.L., Coney, P.J., Berg, H.C., and Plafker, G., this volume, Lithotectonic terrane map and columnar sections for Alaska, in Plafker, G., Jones, D.L., and Berg, H.C., eds., Geology of Alaska: Geological Society of America (Boulder, Colorado), The Geology of North America, scale 1:2,500,000.

Silberman, M.L., Moll, E.J., Chapman, R.M., Patton, W.W., Jr., and Connor, C.L., 1979a, Potassium-argon age of granitic and volcanic rocks from the Ruby, Medfra, and adjacent quadrangles, west-central Alaska: U.S. Geological Survey Circular 804-B, p. B63-B66.

Silberman, M.L., Moll, E.J., Patton, W.W., Jr., Chapman, R.M., and Connor, C.L., $1979 \mathrm{~b}$, Precambrian age of metamorphic rocks from the Ruby province, Medfra and Ruby quadrangles - preliminary evidence from radiometric age data: U.S. Geological Survey Circular 804-B, p. B66-B68.

Smith, G.M., and Puchner, C.M., 1985, Geology of the Ruby geanticline between Ruby and Poorman, Alaska, and the tectonic emplacement of the Ramparts Group:

Eos (American Geophysical Union Transactions) v.46, p 1102.

Smith, G.M., and Rubin, C.M., 1987, Devonian-Mississippian arc from the northern Sierras to the seward Peninsula--record of a protracted and diachronous Antler-age orogeny: Geological Society of America Abstracts with Programs v. 19 , no. 7, p. 849 .

Smith, T.E., 1983, Bedrocks geologic map of the Livengood C-3 quadrangle, Alaska: Alaska Division of Geological and Geophysical Surveys Report of Investigations $83-5$, scale $1: 40,000$.

Struik, L.C., 1981, A re-examination of the type area of the Devono-Mississippian Cariboo orogeny, central British Columbia: Canadian Journal of Earth Sciences v. 18, p. 1767-1775.

----1987, The ancient western North American margin: an alpine rift model for the east-central Canadian Cordillera: Geologic Survey of Canada Paper 87-15, 19 p.

Tailleur, I.L., 1972, Probable rift origin of Canada Basin, Arctic Ocean, in Arctic Geology: American Association of Petroleum Geologists Memoir 19, $p$. $526-535$. 
Tailleur, I.L., and Brosgè, W.P., 1970, Tectonic history of northern Alaska, in Adkinson, W.L., and Brosgè, M.M., eds., Proceedings of the geological seminar on the North Slope of Alaska: American Association of Petroleum Geologists, p. E1-E20.

Tempelman-Kluit, D.J., 1971, Stratigraphy and structure of the "Keno Hill Quartzite" in Tombstone River-Upper Klondike River map areas, Yukon Territory: Geological Survey of Canada Bulletin 180, $102 \mathrm{p}$.

----1977, Stratigraphic and structural relations between the Selwyn basin, PellyCassiar platform, and Yukon crystalline terrane in Pelly Mountains, Yukon: Geological Survey of Canada Paper 77-1A, p. 223-227.

----1979, Transported cataclasite, ophiolite, and granodiorite in Yukon: Evidence of arc-continent collision: Geological Survey of Canada Paper 79-14, 27 p.

--.-1984, Counterparts of Alaska's terranes in Yukon [Abs.], in Symposium-Cordilleran geology and mineral exploration status and future trends: Geological Association of Canada Cordilleran Section (Vancouver, B.C., Canada, Feb. 20-21, 1984), p. 41-44.

Thompson, R.I., and Eisbacher, G.H., 1984, Late Proterozoic rift assemblages, northern Canadian Cordillera: Geological Society of America Abstracts with Programs v. 16 , no. 5 , p. 336.

Thompson, R.I., Mercier, E., and Roots, C.F., 1987, Extension and its influence on Canadian Cordilleran passive-margin evolution, in Coward, M.P., Dewey, J.F., and Hancock, P.L., eds., Continental extensional tectonics: Geological Society Special Publication No. 28, p. 409-417.

Thompson, R.I., and Roots, C.F., 1982, Ogilvie Mountains project, Yukon, part A: A new regional mapping program, in Current Research, part A: Geological Survey of Canada Paper 82-1A, p. 403-411.

Thrupp, G.A., and Coe, R.S., 1986, Paleomagnetic evidence for counter-clockwise rotation of west-central Alaska since the Paleocene [abs.]: Eos (American Geophysical Union Transactions) v. 67, no. 44, p. 921.

Till, A.B., Schmidt, J.M., and Nelson, S.W., 1987, Thrust-involvement of Proterozoic and Mesozoic metamorphic rocks, southwestern Brooks Range, Alaska: Geological Society of America Abstracts with Programs v. 19, no. 6 , p. 458 .

Turner, D.L., Forbes, R.B., and Dillon, J.T., 1979, K-Ar geochronometry of the southwestern Brooks Range, Alaska: Canadian Journal of Earth Sciences $v$. 16 , p. 1789-1804.

Wahrhaftig, C., this volume, Physiographic divisions of Alaska, in Plafker, G., Jones, D.L., and Berg, H.C., eds., Geology of Alaska: Geological Society of America (Boulder, Colorado), The geology of North America, v. , 1 sheet, scale $1: 2,500,000$. 
Weber, F.R., and Foster, H.L., 1982, Tertiary(?) conglomerate and Quaternary faulting in the Circle quadrangle, Alaska: U.S. Geological Survey Circular 844 , p. $58-61$.

Weber, F.R., Smith, T.E., Hall, M.H., and Forbes, R.B., 1985, Geologic guide to the Fairbanks-Livengood area, east-central Alaska: Anchorage, Alaska Geological Society, $44 \mathrm{p}$.

Weber, F.R., Wheeler, K.L., Dover, J.H., Rinehart, C.D., Blodgett, R.B., Cady, J.W., Karl, S.M., Mc Cammon, R.B., and Miyaoka, R., 1988, Geologic framework, in Weber, F.R., McCammon, R.B., Rinehart, C.D., and Light, T.D., Geology and mineral resources of the White Mountain National Recreation Area, east-central Alaska: U.S. Geological Survey Open-File Report 88-284, p 4-58.

Wheeler-Crowder, K.L., Forbes, R.B., Weber, F.R., Rinehart, C.D., 1987, Lithostratigraphy of the ordovician Fossil Creek volcanics with petrology and geochemistry of included metabasalts, white Mountains, east-central Alaska: U.S. Geological Survey Circular 998, p. 70-73.

Williams, G.D., 1985, Thrust tectonics in the south-central Pyrenees: Journal of Structural Geology v. 7, no. 1, p.11-17.

Young, F.G., 1973, Mesozoic epicontinental, flyschoid and molassoid depositional phases of Yukon's north slope, in Aitken, J.D., and Glass, D.J., eds., Proceedings of the Symposium on the geology of the Canadian Arctic: Geological Association of Canada and the Canadian Society of Petroleum Geologists, p. 181-202.

Young, G.M., 1982, The late Proterozoic Tindir Group, east-central Alaska: Evolution of a continental margin: Geological Society of America Bulletin v. 93, no. 8, p. 759-783. 